\title{
Determinants of financial reporting choices : the role of institutional and firm-specific factors
}

Citation for published version (APA):

Cuijpers, R. J. R. (2007). Determinants of financial reporting choices : the role of institutional and firmspecific factors. [Doctoral Thesis, Maastricht University]. Universitaire Pers Maastricht. https://doi.org/10.26481/dis.20070620rc

Document status and date:

Published: 01/01/2007

DOI:

10.26481/dis.20070620rc

Document Version:

Publisher's PDF, also known as Version of record

\section{Please check the document version of this publication:}

- A submitted manuscript is the version of the article upon submission and before peer-review. There can be important differences between the submitted version and the official published version of record.

People interested in the research are advised to contact the author for the final version of the publication, or visit the DOI to the publisher's website.

- The final author version and the galley proof are versions of the publication after peer review.

- The final published version features the final layout of the paper including the volume, issue and page numbers.

Link to publication

\footnotetext{
General rights rights.

- You may freely distribute the URL identifying the publication in the public portal. please follow below link for the End User Agreement:

www.umlib.nl/taverne-license

Take down policy

If you believe that this document breaches copyright please contact us at:

repository@maastrichtuniversity.nl

providing details and we will investigate your claim.
}

Copyright and moral rights for the publications made accessible in the public portal are retained by the authors and/or other copyright owners and it is a condition of accessing publications that users recognise and abide by the legal requirements associated with these

- Users may download and print one copy of any publication from the public portal for the purpose of private study or research.

- You may not further distribute the material or use it for any profit-making activity or commercial gain

If the publication is distributed under the terms of Article $25 \mathrm{fa}$ of the Dutch Copyright Act, indicated by the "Taverne" license above, 
Determinants of Financial Reporting Choices: The Role of Institutional and Firm-Specific Factors 
Determinants of Financial Reporting Choices:

The Role of Institutional and Firm-Specific Factors

Copyright (C) R.J.R. Cuijpers, Maastricht 2007 ISBN 978-90-5278-639-1

Printed by: Universitaire Pers Maastricht 


\title{
Determinants of Financial Reporting Choices: The Role of Institutional and Firm-Specific Factors
}

\author{
Proefschrift
}

ter verkrijging van de graad van doctor

aan de Universiteit Maastricht

op gezag van de Rector Magnificus,

Prof. mr. G.P.M.F. Mols,

volgens het besluit van het College van Decanen,

in het openbaar te verdedigen

op woensdag 20 juni 2007 om 16.00 uur

door

Rick Joseph Rosalina Cuijpers

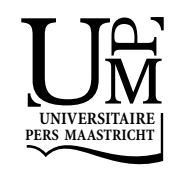




\section{Promotor}

Prof. dr. Frank Moers

\section{Copromotor}

Dr. Erik Peek

\section{Beoordelingscommissie}

Prof. dr. Steven J. Maijoor (voorzitter)

Prof. dr. Rob Bauer

Prof. dr. Willem F.J. Buijink (Universiteit van Tilburg) 


\section{Contents}

Acknowledgements $\quad$ ix

1 Introduction 1

1.1 Introduction 1

1.2 Outline 2

1.3 Contribution 4

1.4 Structure of the dissertation 5

Notes 6

2 Voluntary Adoption of Non-Local GAAP in the European Union:

A Study of Determinants and Consequences $\quad 7$

2.1 Introduction 7

2.2 Voluntary non-local GAAP adoption 9

2.2.1 Background 9

$\begin{array}{ll}2.2 .2 \text { Data collection } & 10\end{array}$

2.3 Determinants of non-local GAAP adoption 14

$\begin{array}{ll}\text { 2.3.1 Stock exchange listings } & 14\end{array}$

$\begin{array}{ll}\text { 2.3.2 International operations } & 15\end{array}$

$\begin{array}{ll}\text { 2.3.3 Country-specific determinants } & 16\end{array}$

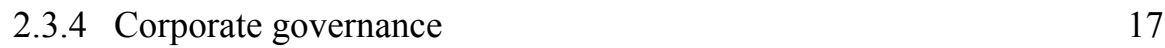

$\begin{array}{lll}2.3 .5 & \text { Size } & 18\end{array}$

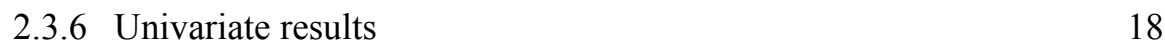

$\begin{array}{lll}\text { 2.3.7 } & \text { Logistic regression results } & 19\end{array}$

2.4 Consequences of non-local GAAP adoption 27

2.4.1 Cost of capital 28

2.4.2 Analyst following 31

2.4.3 Uncertainty 35

2.4.4 Selection bias $\quad 38$

2.5 Discussion and concluding remarks 39

Notes 41 
3 Firm-Level Reporting Incentives and Accounting Properties:

Stakeholder- versus Shareholder-Oriented Governance Structures

3.1 Introduction 45

$\begin{array}{lll}3.2 & \text { Background and hypotheses development } & 48\end{array}$

3.2.1 Dutch accounting regulation 48

3.2.2 Dutch corporate governance 49

3.2.3 Hypotheses development 51

3.3 Research design $\quad 54$

3.3.1 Data and sample selection $\quad 54$

$\begin{array}{ll}3.3 .2 \text { Smoothing } & 57\end{array}$

3.3.3 Conservatism $\quad 58$

3.3.4 Meeting or beating analyst earnings forecasts $\quad 60$

$\begin{array}{lll}3.4 \text { Results } & 61\end{array}$

3.4.1 Smoothing test 61

3.4.2 Conservatism test 63

3.4.3 Meeting or beating analyst earnings forecasts test 64

$\begin{array}{lll}3.4 .4 & \text { Sensitivity analyses } & 67\end{array}$

$\begin{array}{lll}3.5 & \text { Discussion and concluding remarks } & 68\end{array}$

$\begin{array}{ll}\text { Notes } & 70\end{array}$

4 The Effect of Institutional Factors on Accounting Properties for Firms with Different Ownership Structures $\quad 71$

$\begin{array}{lll}4.1 & \text { Introduction } & 71\end{array}$

$\begin{array}{lll}4.2 & \text { Theory and hypotheses } & 74\end{array}$

4.2.1 Objectives of financial reporting 74

4.2.2 Countries' institutional orientation and firms' reporting objectives 75

4.2.3 Reporting objectives of widely held firms across institutional environments $\quad 76$

4.2.4 Reporting objectives of closely held firms across institutional environments 77

4.2.5 The effect of the institutional environment conditional on $\begin{array}{ll}\text { ownership structure } & 78\end{array}$

$\begin{array}{lll}4.3 & \text { Methodology } & 79\end{array}$

$\begin{array}{ll}\text { 4.3.1 Data and sample selection } & 79\end{array}$

$\begin{array}{ll}4.3 .2 \text { Smoothing } & 83\end{array}$

$\begin{array}{ll}4.3 .3 \text { Conservatism } & 85\end{array}$ 
4.4 Results $\quad 86$

4.4.1 Smoothing test 86

$\begin{array}{ll}\text { 4.4.2 Conservatism test } & 87\end{array}$

$\begin{array}{lll}\text { 4.4.3 Sensitivity analyses } & 91\end{array}$

4.5 Discussion and concluding remarks $\quad 91$

Notes 93

5 Summary and Conclusion $\quad 95$

5.1 Introduction 95

5.2 Summary 95

5.3 Limitations and suggestions for future research 98

5.4 Conclusions and implications 99

Notes 104

$\begin{array}{ll}\text { References } & 105\end{array}$

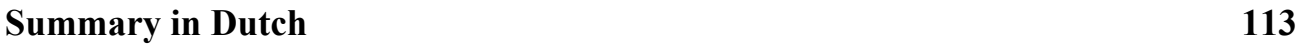

$\begin{array}{ll}\text { Curriculum Vitae } & 117\end{array}$ 



\section{Acknowledgements}

Although writing a doctoral dissertation is primarily an individual effort, I would not have been able to complete it without the help and support of many people. First and foremost, I thank my supervisors Frank Moers and Erik Peek for their support, comments, ideas, and critical views on empirical accounting research: I have learned a lot from our discussions. I thank Rob Bauer, Willem Buijink, and Steven Maijoor for their evaluation and approval of the final version of the manuscript. Each from a different perspective, they have provided useful comments and suggestions. I also thank Willem and Steven for hiring me as a doctoral student and for their supervision during the initial stages of the process.

Furthermore, I thank my current and former colleagues at the Department of Accounting and Information Management of Maastricht University for creating a pleasant and stimulating working environment. I especially thank my fellow (former) doctoral students and roommates Robbert-Paul, Alexander, and Felix for their discussions about various work-related and not-so-work-related matters.

Finally, I thank my parents, my sister, and the rest of my family for their support. But above all, I thank Linda for her love, encouragement, understanding, patience, and for putting up with me.

Rick Cuijpers 



\section{Chapter 1}

\section{Introduction}

\subsection{Introduction}

This dissertation studies the determinants of firms' financial reporting decisions. It presents three empirical studies. The study in chapter 2 describes the determinants and consequences of the choice to voluntarily adopt non-local accounting standards. Chapters 3 and 4 contain studies of the effects of firm-specific and country-specific factors on firms' financial reporting choices.

Firms face reporting choices at different levels. For example, before the European Commission decided to mandate usage of International Financial Reporting Standards (IFRS) across the European Union, firms in many countries were allowed to use U.S. generally accepted accounting principles (U.S. GAAP) or IFRS instead of their local GAAP for consolidated financial reporting. But also within a set of accounting standards, managers can make measurement and disclosure choices, such as the choice of depreciation scheme, the capitalization or expensing of development costs, the classification of a lease as finance or operating lease, or whether to recognize a provision or a contingent liability. These reporting choices are made by managers with certain reporting objectives in mind.

The determinants of firms' reporting objectives and reporting choices are the central theme of this dissertation. I make a distinction between country-specific (institutional) and firm-specific influences on financial reporting. The role that is attributed to accounting information differs internationally (Ali and Hwang 2000; Ball et al. 2000, Leuz et al. 2003). In countries where the rights of minority investors are well protected, capital markets are well-developed, and shareholders are at arm's length from the firms they invest in, financial reporting has an important information function for shareholders. Shareholders demand information about the performance of the firm in contracting with management and in making their investment decisions. On the other hand, in countries where debt financing is more prevalent and large shareholders are actively involved in management of the company or closely monitor management, accounting serves a different role. Information provision to shareholders is not the main objective of financial reporting in these countries. Instead, accounting is used to determine payouts to the various stakeholders of the firm. The main objective of financial reporting in this stakeholder-orientated view is avoiding unwarranted payouts to any stakeholder group, e.g., dividends to shareholders or 
bonuses to managers, in order to ensure the financial health and stability of the firm, which is considered to be in the interest of all stakeholders. The international differences in the role of accounting are also reflected in other institutional characteristics, such as the extent of political influence on the accounting standard setting process, the nature of accounting regulation, the link between financial and tax accounting, and the development of the auditing profession (Ali and Hwang 2000).

Firms' reporting decisions are not solely driven by the institutional environment they operate in, but also differ across firms within countries. Examples of firm-specific influences on reporting choices include firms' ownership structures (Fan and Wong 2002), managerial ownership (Warfield et al. 1995), managerial incentive compensation (Cheng and Warfield 2005), board composition (Vafeas 2000), debt financing, and foreign exchange listings (Meek et al. 1995). For example, shareholders of closely held firms will typically have opportunities and incentives to more directly monitor management than shareholders of widely held firms, which translates into a relatively more important information role of financial reporting for shareholders in widely held firms. Also, the strength of the market for corporate control can influence firms' reporting decisions. Managers of firms that are not protected by takeover defense mechanisms often face pressure from shareholders to reach short-term profit goals, which may encourage earnings management by these firms. Likewise, incentive pay (Cheng and Warfield 2005) and the threat of debt covenant violations (DeFond and Jiambalvo 1994) may influence managers' financial reporting choices.

\subsection{Outline}

The body of this dissertation consists of three empirical studies. Chapter 2 describes a study about the determinants and consequences of voluntary non-local GAAP adoption by listed EU firms. The non-local accounting standards I study are IAS/IFRS ${ }^{1}$ and U.S. GAAP. I choose a research period before the European Commission announced its plans to mandate IAS/IFRS usage in the EU to prevent the effect of the anticipation of mandated usage in firms' decision to switch to non-local standards. Firms can be expected to voluntarily adopt non-local standards when the net benefits of switching from their local GAAP are positive. By studying the characteristics of voluntary adopters, the determinants of adoption can be studied, which sheds light on the distribution of net benefits of non-local GAAP usage across the population of listed EU firms. Furthermore, firms that did not voluntarily switch to non-local standards can be expected to be less likely to fully comply with IAS/IFRS when usage becomes mandatory. Knowing the determinants of adoption can therefore help enforcement institutions direct their efforts. 
The second part of chapter 2 studies the consequences of voluntary non-local GAAP adoption. I empirically investigate the presumption that usage of IAS/IFRS or U.S. GAAP lowers information asymmetries between a firm and its shareholders and consequently leads to a reduction in the cost of equity capital. Although it should be emphasized that the consequences of voluntary adoption of non-local standards could very well be different from the consequences of mandatory adoption, the analyses presented provide information to regulators and capital market participants on the effects of adoption. Furthermore, in an additional analysis, the consequences are analyzed separately for 'early' and 'late' voluntary adopters to examine possible effects over time.

Chapter 3 provides an analysis of the effects of the reporting incentives generated by firms' corporate governance structures in The Netherlands. The shareholder-oriented nature of Dutch accounting regulation coupled with the relatively weak enforcement environment leaves firms considerable discretion in drawing up their financial statements. Furthermore, the governance mechanisms of Dutch publicly listed firms differ widely, which provides them with very diverse reporting incentives. Therefore, this setting provides an interesting opportunity to study the influence of firms' governance structures on their financial reporting in an environment that is characterized by shareholder-oriented accounting regulation. A significant portion of listed firms has concentrated ownership structures and/or takeover defense mechanisms in place, which isolates these firms from the pressure of capital markets and allows them to take the interests of all stakeholders into account in their financial reporting, instead of the interest of shareholders only. Widely held firms without takeover protection face demand from shareholders for informative public reporting and are therefore expected to report shareholder-oriented. I measure a firm's reporting orientation by examining properties of its accounting. Specifically, I expect firms with a stakeholder orientation to report more (unconditionally) conservatively, to more actively smooth earnings, and to engage in less myopic reporting, measured by the tendency to meet or just beat analyst earnings forecasts.

In chapter 4, the effects of the institutional environment on firms' financial reporting objectives conditional on firms' ownership concentration is studied using a sample of Western European firms. I classify countries' institutions as stakeholder- or shareholder-orientated and measure the orientation by constructing a factor score of various country-level influences on accounting. Widely held firms in both stakeholderand shareholder-oriented countries have incentives to report informatively to overcome information asymmetries between the firm and shareholders who are at arm's length. They can do so in stakeholder-oriented environments by choosing options in local accounting standards or by providing additional disclosures. Closely held firms' reporting objectives are congruent with the country's reporting orientation 
in stakeholder-oriented countries. However, in shareholder-oriented countries, firms with concentrated ownership structures face relatively high costs of not complying with the country's institutional orientation. Investor protection rules in these countries protect the interest of minority investors, who demand informative financial reporting. Furthermore, enforcement in these countries tends to be relatively strict. In summary, I hypothesize the influence of institutions on reporting to be more pronounced for closely held than for widely held firms. As in chapter 3, I measure firms' reporting objectives by studying properties of their accounting information and consider (unconditionally) conservative reporting and earnings smoothing as indicative of stakeholder-oriented reporting objectives. ${ }^{2}$

Knowing how firm-specific and institutional factors influence firms' reporting objectives and reporting choices is important to regulators and various stakeholders. Financial statement users have to understand a firm's reporting objectives to assess the information they use for valuing their investments or in contracts with the firm. Also, regulators trying to influence financial reporting practices by changing aspects of the institutional environments faced by firms, have to consider the influence of other institutional and firm-specific factors and their interplay on financial reporting choices.

\subsection{Contribution}

This dissertation contributes to the literature in a number of ways. The study in chapter 2 provides an analysis of voluntary adoption of non-local GAAP across the European Union. The study documents firm-specific and country-specific determinants of voluntary usage of non-local accounting standards in a period before the European Commission announced its plans to mandate usage of IAS/IFRS. As such, it provides insight into the factors that contribute to firms experiencing net benefits from adoption of non-local accounting standards. Furthermore, it provides some evidence regarding the consequences of adoption.

The studies in chapters 3 and 4 study the influence of firm-specific and institutional factors on firms' reporting behavior. The study in chapter 3 uses the unique setting in The Netherlands to examine the influence of the reporting incentives generated by firms' governance structures in a situation where accounting regulation is shareholder-oriented and highly comparable to IAS/IFRS. In chapter 4, I study the influence of country-specific institutional factors on reporting behavior for firms with different levels of ownership concentration. Most prior literature does not consider the moderating role of firm-specific reporting incentives. However, I find evidence to suggest that the effect of institutions on financial reporting choices is conditional on a firm's ownership structure. 


\subsection{Structure of the dissertation}

The remainder of this dissertation is organized as follows. Chapter 2 describes an empirical study on the determinants and consequences of non-local GAAP adoption in the European Union. In chapter 3, the influence of firms' corporate governance structures on properties of accounting information is analyzed. Chapter 4 deals with the effects of institutional and firm-specific incentives on accounting properties. The final chapter presents a summary and conclusion of this dissertation. 


\section{Notes}

1 The terms International Accounting Standards (IAS) and International Financial Reporting Standards (IFRS) are used interchangeably throughout this dissertation. IAS standards were issued by the International Accounting Standards Committee (IASC), whereas IFRS standards are issued by the International Accounting Standards Board (IASB, the successor body to the IASC). International Financial Reporting Standards is now the official name that the IASB uses for all IAS and IFRS standards issued. For more information, see http://www.iasb.org.

2 In chapter 4, I do not study the tendency to meet or beat analyst earnings forecasts, one of the accounting properties I investigate in chapter 3, because I do not have data available for all countries included in the sample. 


\section{Chapter 2}

\section{Voluntary Adoption of Non-Local GAAP in the European Union: A Study of Determinants and Consequences*}

\subsection{Introduction}

In recent years, economic and regulatory changes may have provided firms with incentives to voluntarily prepare their financial statements according to different accounting standards than those of their home country. Within the European Union (EU) important developments in this respect are the merger of several stock exchanges, initiatives at the International Organisation of Securities Commissions (IOSCO) and the International Accounting Standards Board (IASB), and the efforts of the European Commission (EC) to harmonize financial reporting.

This study examines both the determinants and consequences of voluntary adoption of non-local generally accepted accounting principles (GAAP) by non-financial firms domiciled and listed in the EU. I focus on voluntary adoption of International Accounting Standards (IAS) and United States (U.S.) GAAP, the two predominant internationally accepted sets of standards. The maintained hypothesis in this chapter is that firms choose to report according to non-local GAAP if the benefits outweigh the costs associated with the switch from their local GAAP. By documenting the determinants of non-local GAAP adoption, I am providing indirect evidence of benefits and costs of adoption. I also directly examine the consequences of non-local GAAP adoption by testing whether firms using IAS or U.S. GAAP experience lower levels of information asymmetry, a much cited benefit of increased financial reporting transparency, than firms using local GAAP.

Unlike previous studies on voluntary adoption of IAS and/or U.S. GAAP (e.g., Dumontier and Raffournier 1998; El-Gazzar et al. 1999; Murphy 1999; Joos and Weets 2000; Leuz and Verrecchia 2000; Ashbaugh 2001; Leuz 2003), that focus on a very narrow (single country or stock exchange) or very heterogeneous group of firms, I study a fairly large homogeneous group of firms, by focusing on listed EU firms.

\footnotetext{
* This chapter is published as: Cuijpers, R. and W. Buijink (2005). Voluntary Adoption of Non-Local GAAP in the European Union: A Study of Determinants and Consequences. European Accounting Review 14, 487-524. The literature in this chapter has not been updated to include more recent studies on (voluntary) IAS/IFRS adoption.
} 
Furthermore, I contribute to the scarce evidence (Auer 1996 1998; Leuz and Verrecchia 2000; Ashbaugh and Pincus 2001) on the consequences of non-local GAAP adoption.

A central problem for a study such as this is to establish which firms fully adopt non-local GAAP. I use information from the IASB web site, financial statement databases, and some other sources to identify listed EU firms using non-local GAAP in their 1999 fiscal year. I then inspect the notes and audit reports in the consolidated annual reports of all these firms to verify that they are stating compliance with IAS or U.S. GAAP. This represents a major difference with some earlier studies. Ashbaugh (2001), for example, also includes firms that only provide footnote reconciliations to IAS or U.S. GAAP. The firms that I study are making a much stronger commitment to report according to non-local GAAP by drawing up their entire financial statements in accordance with IAS or U.S. GAAP.

I find that 133 non-financial firms domiciled and listed in the EU report according to non-local GAAP. This finding itself strongly suggests that by 1999/2000 most listed EU firms do not expect to benefit from switching to non-local accounting standards. Furthermore, I find that firms adopting non-local GAAP are more likely to be listed on a U.S. exchange, the EASDAQ exchange in Brussels, and have more geographically dispersed operations. Also, these firms are more likely to be domiciled in a country with lower quality financial reporting and where IAS is explicitly allowed as an alternative to local GAAP.

I find mixed evidence on the consequences of non-local GAAP adoption. The findings do not show a lower cost of equity capital for adopters, but I do find that non-local GAAP users are followed more heavily by financial analysts. This latter finding applies specifically to firms that have been using IAS or U.S. GAAP for a longer period of time ('early' adopters). Consistent with prior literature (Leuz and Verrecchia 2000), I do not find any significant differences in stock return volatility between local and non-local GAAP users, but I document a higher dispersion of analyst earnings forecasts for non-local GAAP adopters. When comparing 'early' and 'late' non-local GAAP adopters, I find that only 'late' adopters have higher forecast dispersion. This finding suggests that analysts need time to learn to interpret a firm's financial statements drawn up under IAS or U.S. GAAP or that firms that recently switched are not yet perfectly complying with non-local GAAP.

The remainder of this chapter is organized as follows. In the next section I provide a short background for this study, followed by a description of the data collection. The analysis of the determinants of non-local GAAP adoption is reported in section 3. In section 4 I study the consequences of adoption, by testing whether IAS or U.S. GAAP adoption reduces information asymmetry. The final section of this chapter contains a discussion of the findings and some concluding remarks. 


\subsection{Voluntary non-local GAAP adoption}

\subsubsection{Background}

Several developments may have motivated firms to prepare financial statements in accordance with non-local GAAP. Potentially the most important development is the rapid worldwide economic integration and the associated increase in cross-border capital flows. In the EU one recent manifestation of this phenomenon was the merger of three stock exchanges (Paris, Brussels, and Amsterdam). Also, the IOSCO has recommended its members to allow multinationals that are planning cross-border exchange listings to prepare their financial statements according to IAS (IOSCO 2000). Already many stock market regulators allow (foreign) registrants to prepare their consolidated financial statements using non-local GAAP, sometimes with a requirement to provide a reconciliation to local GAAP. ${ }^{1}$ In the EU this is the case in most member states.

There were also some relevant developments on the regulatory side. In 1995 the EC recognized the need for further harmonization of financial reporting in the EU going beyond the level achieved by the European Accounting Directives (Commission of the European Communities 1995). The EC expressed its support for IAS, the standards issued by the IASC (the International Accounting Standards Committee, the predecessor body to the IASB). In February 2001 the EC proposed a requirement for all EU domiciled firms listed on stock exchanges within the EU to prepare their financial statements in accordance with IAS by 2005 (Commission of the European Communities 2001b). The European Parliament and the Council adopted the regulation prepared by the EC in May 2002 (European Parliament and Council 2002).

At the time of the study, there is no EU regulator mandating firms to use non-local accounting standards, except for the Deutsche Börse, which required firms traded on the Neuer Markt ('New Market') segment to use either IAS or U.S. GAAP. The EASDAQ (NASDAQ Europe) exchange in Brussels requires firms to fully adopt or prepare a reconciliation to either IAS or U.S. GAAP. Most firms can therefore voluntarily adopt IAS or U.S. GAAP for financial reporting.

EU firms can use non-local GAAP for financial reporting in a number of ways. An extreme option is to provide two separate sets of financial statements: one using local GAAP (to satisfy regulatory requirements) and another one using non-local GAAP. A second possibility is to report according to non-local GAAP and provide a reconciliation to local GAAP. Third, some firms have the option to comply with two sets of accounting standards by choosing certain accounting measurement options in local GAAP that are in accordance with non-local GAAP and provide additional disclosures that may be required under non-local GAAP. Finally, if allowed by the national (stock exchange) regulators, firms can provide financial statements that 
comply only with non-local GAAP. I classify firms that choose one of the four options described above, as complying with non-local GAAP. For the purposes of this chapter, I do not consider preparing financial statements in accordance with local GAAP and providing a reconciliation to IAS or U.S. GAAP as complying with non-local accounting standards.

\subsubsection{Data collection}

I attempt to identify an as large as possible number of firms from the EU member states using non-local GAAP in the preparation of their financial statements. The selection procedure is as follows. Based on a number of sources (described below) initial groups of listed EU firms possibly using IAS and U.S. GAAP are formed. To be included in this initial group the firms have to appear on the Worldscope database (December 2000 version). For the firms in the initial group I subsequently verify that they are actually stating compliance with non-local GAAP by inspecting the notes and the audit report contained in the annual reports. For each firm the annual report of the first fiscal year starting on or after July 1, 1998 (the 1999 annual report) is inspected, because IAS 1 stipulates that from this date on:

"An enterprise whose financial statements comply with International Accounting Standards should disclose that fact. Financial statements should not be described as complying with International Accounting Standards unless they comply with all the requirements of each applicable Standard and each applicable Interpretation of the Standing Interpretations Committee.” (IAS 1, Emphasis added.)

Therefore, if a firm refers to the use of IAS in its annual report, it is effectively stating compliance with all applicable standards and interpretations. I inspect the annual reports of possible U.S. GAAP adopters for the same period. I do not examine a later period, because with the proposal by the EC in February 2001 it became clear that IAS usage would be mandated from 2005 on.

I leave Italian firms out of the initial group of firms possibly using IAS, because they are known to frequently refer to IAS in the absence of local standards, without fully complying with IAS (Zambon 1998: 572). ${ }^{2}$ However, for three Italian firms previously identified as complying with IAS, of which only two are on the Worldscope database, IAS compliance is verified. Several data sources were combined in an attempt to identify the initial group of firms in the EU possibly using IAS. First, I obtained a list of 'Companies referring to their use of IAS', dated May 2000, from the IASC. ${ }^{3}$ This list identifies 239 firms domiciled in one of the EU member states (excluding Italy). I downloaded a similar, but updated list from the IASC web site in February 2001 (IASC 2001). This list contains 80 EU firms that published annual 
reports in 1999/2000 that fully comply with IAS. ${ }^{4}$ In addition I searched two financial statement databases for listed firms using IAS. I searched the Worldscope database (December 2000 version) for EU firms using 'international standards' or 'local standards with some IASC guidelines, ${ }^{5}$ as their accounting standards. This search returned 172 (non-Italian) firms. I also used COMPUSTAT's Global Vantage database (May 2001 version) to search for EU firms (again excluding Italy) using accounting standards ${ }^{6}$ 'generally in accordance with IASC guidelines' and 'generally in accordance with IASC and OECD guidelines'. Global Vantage returned 224 firms. Furthermore, I checked the 165 firms referring to IAS in their 1999 financial statements that are included in the sample of a survey by Cairns (2001). Of these firms 79 are domiciled in one of the EU member states (excluding Italy). Combining these sources and screening for presence of these firms on the Worldscope database resulted in an initial group of 360 possible IAS users (see Table 2.1, Panel A). ${ }^{7}$

I undertook a similar procedure to form an initial group of firms possibly using U.S. GAAP. The two financial statement databases described earlier (Worldscope and Global Vantage) were used to identify EU firms that use U.S. GAAP in their 1999 financial statements. Worldscope included 71 firms using 'U.S. GAAP' or 'U.S. GAAP reclassified from other standards'. Global Vantage listed 139 firms using either 'United States' standards', 'domestic standards generally in accordance with United States GAAP', or 'domestic standards generally in accordance with principles generally accepted in the United States'. Combining these two lists of firms, again by checking for presence on the Worldscope database, leaves an initial group of 163 firms (see Table 2.1, Panel B).

I contacted all firms in the initial group of possible IAS (U.S. GAAP) users to obtain their 1999 annual reports. I could not obtain the annual reports of 26 (38) firms because they were taken over, merged with another firm, became inactive, were no longer or not yet listed on an exchange in 1999, or did not reply to the information requests. I examined the annual reports of the remaining firms to verify their use of IAS (U.S. GAAP), by inspecting (1) the notes to the financial statements and (2) the audit report. A firm was kept in the group of IAS (U.S. GAAP) adopters if the notes or the audit report stated full compliance with IAS (U.S. GAAP). As can be seen from Table 2.1, I found no disclosure of compliance with IAS (U.S. GAAP) for 139 (31) of firms in the initial group, leaving 195 (96) firms. Because of differing financial reporting regulations in most countries, firms in the financial industries (SIC code 6) were deleted. ${ }^{8}$ I also deleted firms without a listing in the EU and firms listed on the Neuer Markt segment of the Deutsche Börse. This leaves 133 listed non-financial EU firms voluntarily using non-local GAAP (92 IAS and 41 U.S. GAAP users). 
When analyzing the distribution of firms across countries (see Table 2.2) it becomes clear that firms using non-local GAAP are concentrated in specific countries. Most firms using IAS are domiciled in Germany, Austria, or France. Concentrations of

\section{Table 2.1}

Identification of firms using non-local GAAP

Panel A Firms using IAS

Source

Number of

Firms on

Source

firms

Worldscope

IASC list May 2000

IASC list February 2001

$239 \quad 216$

Worldscope (WS) database

$80 \quad 74$

Global Vantage (GV) database

Cairns

Italian firms possibly using IAS

Group of firms to be verified

Not verified (taken over, merged, became inactive, no longer or not yet

listed on an exchange in 1999, or no reply to information requests)

No disclosure of compliance with IAS

Financial firms (SIC code 6, or unknown)

Listed on the Neuer Markt segment of the Deutsche Börse

Non-financial firms voluntarily disclosing compliance with IAS

Insufficient data availability ${ }^{\mathrm{a}}$

IAS adopters used in analyses

Panel B Firms using U.S. GAAP

Source

Number of

Firms on

firms

Worldscope

Worldscope (WS) database

Global Vantage (GV) database

Group of firms to be verified

listed on an exchange in 1999, or no reply to information requests)

No disclosure of compliance with U.S. GAAP

U.S. GAAP adopters identified using other sources

Financial firms (SIC code 6, or unknown)

Listed on the Neuer Markt segment of the Deutsche Börse

Non-financial firms voluntarily disclosing compliance with U.S. GAAP Insufficient data availability ${ }^{\mathrm{a}}$

U.S. GAAP adopters used in analyses

a Includes Luxembourgian firms, because of unavailability of data on one of the independent regression variables $\left(Q_{-} A C C\right)$. 
U.S. GAAP adopters are found in Germany, France, and The Netherlands. No firms from the United Kingdom, Ireland, Portugal, or Sweden were identified as adopters of non-local GAAP. For the UK and Ireland, the most likely reasons for this finding are the similarity between IAS, U.S. GAAP, and UK GAAP and the relatively high quality of UK accounting standards (Haller 2002). Firms domiciled in these two countries are therefore not included in the subsequent analyses. ${ }^{9}$ I also have to exclude firms domiciled in Luxembourg, because of unavailability of data on one of the independent variables (quality of accounting standards, discussed later). Deleting firms with insufficient data available on the Worldscope database leaves 114 non-local GAAP adopters (80 IAS and 34 U.S. GAAP) for further analysis. Table 2.2 shows how the net benefits of non-local GAAP adoption are distributed across the society of EU countries.

To investigate the determinants of non-local GAAP adoption, all 1679 non-financial firms listed and domiciled in the EU (excluding firms domiciled in the UK, Ireland, and Luxembourg and firms that are listed on the Neuer Markt) that do not

Table 2.2

Distribution of firms by accounting standards used and country of domicile ${ }^{a}(n=1,793)$

\begin{tabular}{|c|c|c|c|c|c|c|c|c|}
\hline \multirow[b]{2}{*}{ Country } & \multicolumn{2}{|c|}{ IAS } & \multicolumn{2}{|c|}{ U.S. GAAP } & \multicolumn{2}{|c|}{$\begin{array}{c}\text { Non-local } \\
\text { GAAP } \\
\text { (IAS and U.S. } \\
\text { GAAP) }\end{array}$} & \multicolumn{2}{|c|}{ Local GAAP } \\
\hline & $\mathrm{n}$ & $\%$ & $\mathrm{n}$ & $\%$ & $\mathrm{n}$ & $\%$ & $\mathrm{n}$ & $\%$ \\
\hline Austria & 16 & 20.0 & 1 & 2.9 & 17 & 14.9 & 35 & 2.1 \\
\hline Belgium & 4 & 5.0 & 1 & 2.9 & 5 & 4.4 & 83 & 4.9 \\
\hline Denmark & 7 & 8.8 & 1 & 2.9 & 8 & 7.0 & 98 & 5.85 \\
\hline Finland & 2 & 2.5 & 0 & 0.0 & 2 & 1.8 & 105 & 6.3 \\
\hline France & 11 & 13.8 & 12 & 35.3 & 23 & 20.2 & 460 & 27.4 \\
\hline Germany & 35 & 43.8 & 8 & 23.5 & 43 & 36.0 & 245 & 14.6 \\
\hline Greece & 2 & 2.5 & 0 & 0.0 & 2 & 1.8 & 119 & 7.1 \\
\hline Italy & 1 & 1.3 & 0 & 0.0 & 1 & 0.9 & 120 & 7.1 \\
\hline The Netherlands & 1 & 1.3 & 11 & 32.4 & 12 & 10.5 & 140 & 8.3 \\
\hline Portugal & 0 & 0.0 & 0 & 0.0 & 0 & 0.0 & 23 & 1.4 \\
\hline Spain & 1 & 1.3 & 0 & 0.0 & 1 & 0.9 & 67 & 4.0 \\
\hline Sweden & 0 & 0.0 & 0 & 0.0 & 0 & 0.0 & 184 & 11.0 \\
\hline Total & 80 & 100.0 & 34 & 100.0 & 114 & 100.0 & 1,679 & 100.0 \\
\hline Adoption \% & \multicolumn{2}{|c|}{4.5} & \multicolumn{2}{|c|}{1.9} & \multicolumn{2}{|c|}{6.4} & \multicolumn{2}{|c|}{93.6} \\
\hline
\end{tabular}

a Only cases with full data available for the analyses are tabulated. Firms from the UK and Ireland are excluded because of the comparable high quality of UK GAAP and the non-local GAAPs studied (IAS and U.S. GAAP). Luxembourgian firms are excluded from further analyses, because of unavailability of data on one of the independent variables $\left(Q_{-} A C C\right)$. 
use IAS or U.S. GAAP and have sufficient data available on the WS database are used as a control group. I use such a large control group to keep the fraction of non-local GAAP adopters close to the 'real' rate of adoption. ${ }^{10}$ The rate of adoption of non-local GAAP in my group of firms is only $6.4 \%$ (4.5\% use IAS and $1.9 \%$ use U.S. GAAP, see Table 2.2). This percentage is higher than the true percentage of non-local GAAP adopters, because relatively more firms using local GAAP are deleted due to data unavailability and because I exclude firms from the UK and Ireland. It should be noted that the number of firms listed in Table 2.2 represent the observations used in the analysis of determinants in section 3 . When testing the consequences of non-local GAAP adoption in section 4 I lose more observations because the analyses, among others, require $\mathrm{I} / \mathrm{B} / \mathrm{E} / \mathrm{S}$ earnings forecast data.

\subsection{Determinants of non-local GAAP adoption}

Using IAS or U.S. GAAP typically implies using stricter measurement rules and making more disclosures in financial statements than would be required under a firm's local GAAP. If a firm therefore chooses to report according to IAS or U.S. GAAP it is voluntarily making a commitment to providing more, and more standardized information to capital markets (Leuz and Verrecchia 2000; Ashbaugh 2001). The maintained hypothesis is that firms will switch from local to non-local GAAP if the benefits of adoption outweigh the costs. The expected determinants of voluntary non-local GAAP adoption described below are mainly based on earlier studies on the adoption of non-local GAAP and on voluntary disclosure literature in general.

\subsubsection{Stock exchange listings}

Firms with international stock exchange listings face additional capital market pressures (Meek et al. 1995) and stock exchange requirements (Cooke 1992) that may lead them to increase their level of disclosure. Investors demand information about the domestic operating environment and domestic accounting regulations of foreign listed firms (Nobes and Parker 1998). Also, firms will incur costs to comply with the regulations of the different stock exchanges that they decide to list on (Biddle and Saudagaran 1991), and as Saudagaran and Biddle (1995) point out: 'these costs can be significant'. In order to meet foreign investors' demand and comply with foreign exchange regulations, firms may be motivated to report according to an internationally accepted set of accounting principles. In fact, many stock exchanges around the world allow foreign registrants to prepare their financial statements according to IAS or U.S. GAAP. Prior studies show that the level of disclosure (Cooke 1992; Meek et al. 1995) and the probability of using non-local GAAP (El-Gazzar et al.; 1999; Murphy 1999; 
Ashbaugh 2001) are positively associated with the number of foreign stock exchange listings of a firm.

I expect the net benefits of non-local GAAP adoption to be higher for firms listed on more exchanges. Because within the EU there is a mutual recognition ${ }^{11}$ of each member states' accounting standards (Fédération des Experts Comptables Européens 1993), this mainly applies to firms listed on exchanges outside the EU. However, I even expect firms without listings outside the EU to have an incentive to adopt non-local GAAP, because they can provide more standardized information to foreign investors by using IAS or U.S. GAAP.

The Neuer Markt (NM), the 'new market' segment of the Deutsche Börse, obliges firms to use either IAS or U.S. GAAP. Because firms traded on the NM are constrained in their choice of GAAP (they do not voluntarily choose to report according to non-local GAAP), they will be excluded from the analyses. Firms listed on one or more U.S. exchanges either have to fully adopt or reconcile to U.S. GAAP. Likewise, the EASDAQ exchange obliges firms to fully adopt IAS or U.S. GAAP, or to provide a reconciliation to either set of GAAP. Like firms with a U.S. listing, firms listed on the EASDAQ exchange will bear the cost of providing a reconciliation if they decide to report according to their local GAAP. Firms may be reluctant to provide a reconciliation, because this requires them to report two (diverging) earnings figures. This could cause confusion among investors and reduce their trust in the financial reporting of a firm, because they are unable to identify true economic performance. I therefore expect firms listed in the U.S. or traded on the EASDAQ exchange to be more likely to report according to non-local GAAP.

I realize that the trade-off for these firms (reporting according to non-local GAAP or preparing a reconciliation to non-local GAAP) is likely to be fundamentally different than for other firms. Therefore, I perform a sensitivity analysis, where I repeat the main analysis of determinants, excluding firms listed in the U.S. or on the EASDAQ exchange.

\subsubsection{International operations}

Typically, firms operating internationally have a much more heterogeneous group of stakeholders than firms that mainly operate nationally. Even without foreign stock exchange listings, I expect demand for more standardized information from these different interest groups. Dumontier and Raffournier (1998), El-Gazzar et al. (1999), and Murphy (1999) find that firms using IAS have more foreign operations. I therefore expect firms operating on an international scale to be more likely to adopt non-local GAAP. 


\subsubsection{Country-specific determinants}

I expect the net benefits of non-local GAAP adoption to depend on the country-specific institutional environment of a firm. Firms domiciled in countries with accounting standards of lower quality that want to provide high quality accounting information, can use IAS or U.S. GAAP as a strong signal of their commitment to higher quality financial reporting. The net benefits to firms from countries with high quality financial reporting are much lower, because by reporting according to their local GAAP they are already providing high quality accounting information. For firms in these countries, the costs of adopting IAS or U.S. GAAP could very well outweigh the benefits.

For each country represented in her sample, Ashbaugh (2001) develops a measure of the differences between IAS or U.S. GAAP and local GAAP, based on a number of disclosure and measurement issues. She finds that firms domiciled in countries where local accounting standards differ more from IAS or U.S. GAAP are more likely to adopt non-local GAAP. However, the measure only focuses on the major differences between local and non-local GAAP. I decide to use a more general measure of the quality of a country's financial reporting. ${ }^{12}$ I measure reporting quality by a score published by the Center for International Financial Analysis and Research (CIFAR). The CIFAR score is constructed by investigating the disclosure of 90 items in the annual reports of firms (La Porta et al. 1998). ${ }^{13}$ I expect the net benefits of non-local GAAP adoption to be higher for firms from countries with low quality domestic financial reporting.

The general quality of financial reporting in a country also depends on the enforcement of accounting standards. However, this does not have a direct effect on the choice between local and non-local GAAP, because the enforcement environment of a firm will not change by merely adopting IAS or U.S. GAAP for financial reporting. Indirectly, firms may try to overcome the weaknesses of their domestic enforcement mechanisms by committing themselves to higher quality financial reporting. I address the role of enforcement in an additional analysis.

In some EU members states usage of IAS is explicitly allowed as an alternative to using local accounting standards for consolidated financial reporting. This is the case in Austria, Belgium, Finland, France, Germany, Italy, and Luxembourg (Commission of the European Communities 2001a). The costs of adopting non-local will be lower for firms domiciled in one of these countries, because they will surely not face any reconciliation requirements to local GAAP if they switch to IAS. I therefore expect adoption of non-local GAAP to be higher in these countries. 


\subsubsection{Corporate governance}

Public disclosures of firms can be expected to reflect their governance structure. Firms with many 'inside' stakeholders have fewer incentives to disclose high quality financial information than firms that rely primarily on 'outsiders' to provide the necessary capital. This is because 'insiders' to the firm are not dependent on public disclosures, whereas for firms with many outside stakeholders, public disclosures are the only economically feasible way to resolve possible information asymmetry problems. I therefore expect the use of high-quality accounting standards for financial reporting, targeted at the interests of equity investors, like IAS or U.S. GAAP, to be higher for firms with many outside stakeholders. This study measures the 'inside' or 'outside' orientation of a firm in two ways: (1) the percentage of debt in a firm's capital structure and (2) a measure of stock ownership concentration.

Previous studies on voluntary disclosure have often used a firm's capital structure as a proxy for their governance structure (Chow and Wong-Boren 1987; Meek et al. 1995; Zarzeski 1996; Jaggi and Low 2000). Different authors however, hypothesize different relationships between capital structure and disclosure. Meek et al. (1995) argue that voluntary disclosures can be expected to increase with leverage, because in firms with proportionally more debt, the potential wealth transfers from debt holders to stockholders and managers (agency costs) are larger. Zarzeski (1996) expects to find a negative relationship between disclosure and leverage, assuming that firms with high debt ratios are located in countries with strong banking relationships and many interlocking corporate ownerships (a bank-oriented financial system). In these countries there is less need for high quality financial reporting, as many stakeholders are 'insiders' to the firm and rely on private rather than public information to make decisions. These two different lines of reasoning illustrate the inability of leverage alone to be a good proxy for the governance structure of a firm.

I use leverage as a proxy for the level of 'inside' orientation of a firm, because providers of debt finance, such as banks, are typically less dependent on public disclosures of firms than shareholders. However, this argument does not apply to public debt. Unfortunately, I cannot control for this, because I am unable to make a distinction between public and private debt based on the data.

Equity investors are usually 'outsiders' to a firm. However, if a shareholder owns a large stake in a firm, the dependence on public disclosure is likely to be smaller, because he can directly monitor management. Therefore, in addition to leverage, I use concentration of stock ownership as a proxy for a firm's 'inside' governance.

I expect the two proxies for a firm's governance structure (leverage and stock ownership concentration) to be negatively related to non-local GAAP adoption 
because they both measure the 'inside' governance orientation of a firm. The net benefits of non-local GAAP adoption will likely be less for firms with stakeholders that are 'insiders' to the firm. These expectations are supported by El-Gazzar et al. (1999), who find a negative relation between the debt to equity ratio and the probability of IAS adoption, and Dumontier and Raffournier (1998), who find that Swiss IAS adopters have more diffuse ownership than firms using local GAAP.

\subsubsection{Size}

Voluntary disclosure research has consistently found that larger firms provide stakeholders with more disclosures (Chow and Wong-Boren 1987; Cooke 1992; Lang and Lundholm 1993; Meek et al. 1995; Zarzeski 1996; Ashbaugh 2001; Jaggi and Low 2000). It is however unclear what factors the size variable is actually representing. Costs of disclosure appear to be decreasing in firm size. One component of disclosure costs is information production costs, for which the fixed component can be spread over more 'units of size' in large organizations. Also, because larger firms generally have higher levels of analyst following, information dissemination, transaction, and competitive disadvantage costs (Foster 1986; Lang and Lundholm 1993) are reduced. Higher political costs, caused by higher public exposure, and agency costs, caused by more widely dispersed ownership, may also drive larger firms to voluntarily make more disclosures (Foster 1986; Meek et al. 1995). Because the choice to adopt non-local GAAP represents a commitment to making more disclosures than would typically be required under local GAAP, I expect the documented positive relation to hold in my setting as well.

\subsubsection{Univariate results}

Descriptive statistics and univariate results for the firms included in the analysis can be found in Table 2.3. Wilcoxon two-sample tests indicate that firms using non-local GAAP to draw up their financial statements are more likely to be (1) listed on more EU $\left(E U_{-} E X\right)$ and non-EU (NONEU_EX) exchanges (2), listed in the U.S. (US_EX), (3) listed on the EASDAQ exchange $(E A S D A Q)$, (4) operating in a larger number of geographic segments $\left(G E O \_S E G M\right)$, (5) domiciled in countries with lower quality accounting standards $\left(Q \_A C C\right)$, (6) domiciled in countries where IAS is explicitly allowed as an alternative to local GAAP (IAS_ALLOW), and (7) larger in terms of market capitalization $\left(M R K T \_C A P\right)$. Contrary to expectations, firms using non-local GAAP have a higher ownership concentration (OWN_CONC) and do not differ significantly in terms of their long-term debt to assets ratio (DEBT).

I also test for industry effects in the choice between local and non-local GAAP. The level of voluntary disclosure may differ between industries because of industry 
specific accounting regulation, competitive pressures (Cooke 1992), or proprietary costs (Meek et al. 1995). These factors may also cause industry differences in the costs and benefits of adopting non-local GAAP. The industry analysis reveals that manufacturing firms (SIC codes 2 and 3) are more likely to use non-local GAAP, whereas firms in agriculture, forestry, fishing, mining, and construction (SIC codes 0 and 1) and retail and wholesale trade (SIC code 5) are less likely to adopt IAS or U.S. GAAP.There are no significant differences for firms in transportation, communications, electric, gas, and sanitary services (SIC code 4) and services (SIC code 7 and 8 ).

The Pearson and Spearman correlations between the independent variables (determinants) are shown in Table 2.4. The correlation between some of these variables is rather high. High correlation between independent variables can cause problems of multicollinearity in the regression analyses. I will address this issue below.

\subsubsection{Logistic regression results}

The method used to study the determinants of non-local GAAP adoption is similar to that used in other papers on the subject (e.g., Ashbaugh 2001). In a logistic regression a binary variable indicating whether a firm is using local or non-local GAAP is regressed on a number of explanatory variables representing firm- and country-specific characteristics expected to influence non-local GAAP adoption. Specifically, I estimate the following logistic regression model:

$$
\begin{aligned}
& P(G A A P)=\beta_{0}+\beta_{1} E U_{-} E X+\beta_{2} N O N E U_{-} E X+\beta_{3} U S_{-} E X+\beta_{4} E A S D A Q+ \\
& \beta_{5} G E O_{-} S E G M+\beta_{6} Q_{-} A C C+\beta_{7} I A S_{-} A L L O W+\beta_{8} O W N_{-} C O N C+ \\
& \beta_{9} D E B T+\beta_{10} M R K T_{-} C A P+\sum_{k=1}^{4} \kappa_{k} I N D U S T R Y_{k}+\varepsilon
\end{aligned}
$$

where GAAP is an indicator variable taking the value 1 if the firm uses non-local GAAP and 0 otherwise, $E U_{-} E X\left(N O N E U_{-} E X\right)$ is the number of EU (non-EU) stock exchange listings of a firm, $U S \_E X(E A S D A Q)$ is an indicator variable taking the value 1 if a firm is listed on a U.S. exchange (the EASDAQ exchange) and 0 otherwise, $G E O \_S E G M$ is the number of geographic segments reported by a firm, $Q_{-} A C C$ is a measure of the quality of a country's accounting standards published by CIFAR (La Porta et al. 1998, Table 2.5), IAS_ALLOW is an indicator variable taking the value 1 if a firm is domiciled in one of the seven EU member states (Austria, Belgium, Finland, France, Germany, Italy, and Luxembourg) that explicitly allow usage of IAS (Commission of the European Communities 2001a), OWN_CONC is a Herfindahl concentration index based on the ownership percentages of the ten largest shareholders of a firm (only shareholdings of 5\% or more are available), DEBT is a firm's long-term 


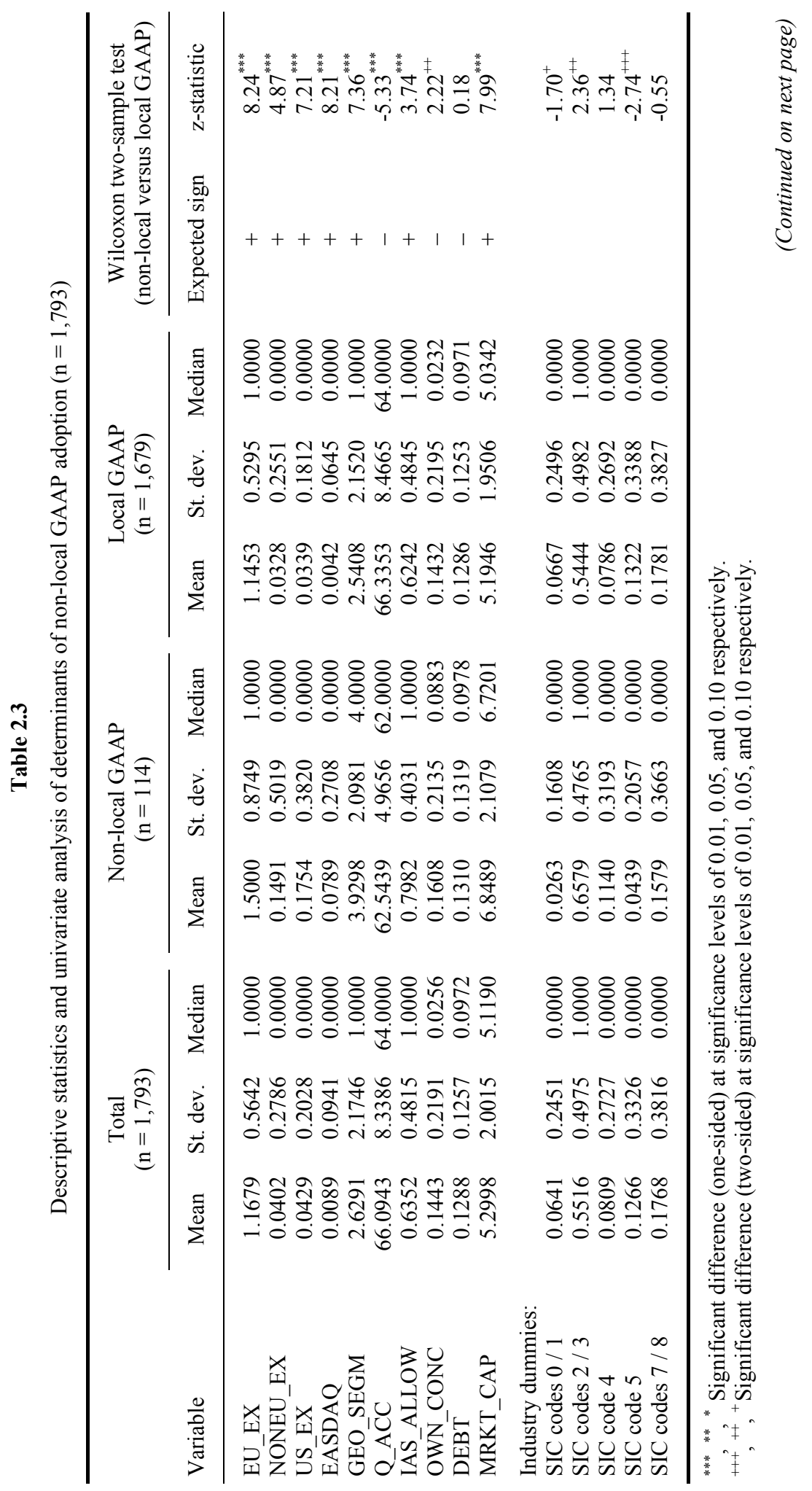




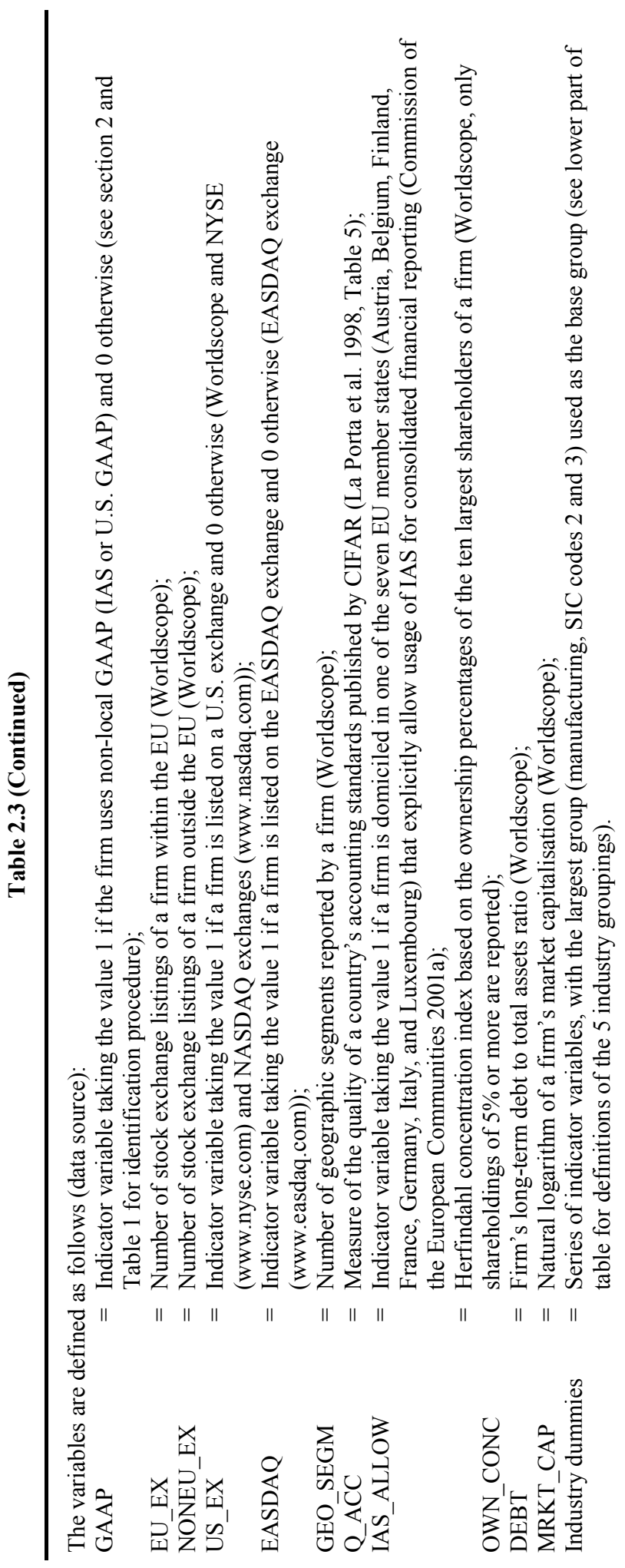




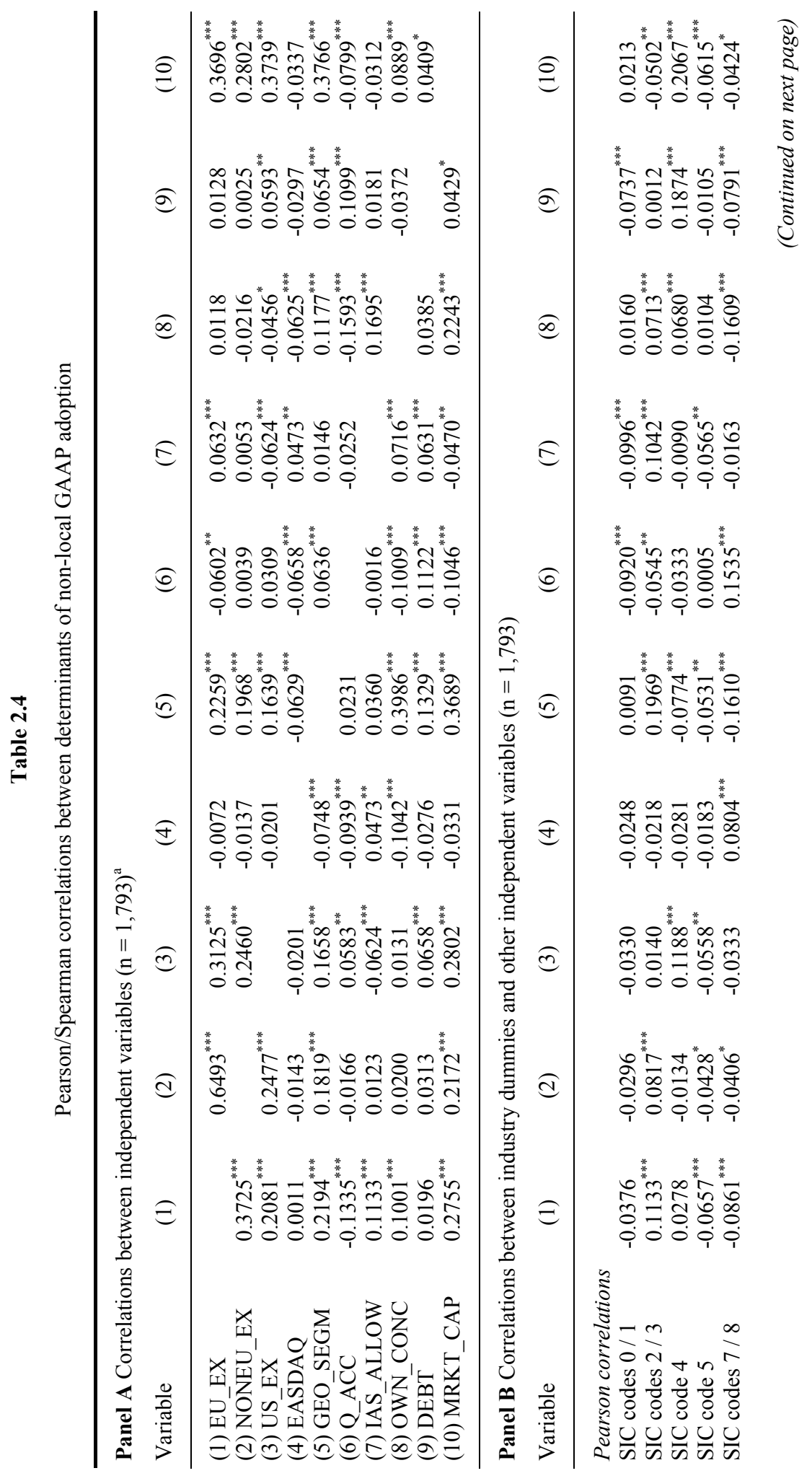




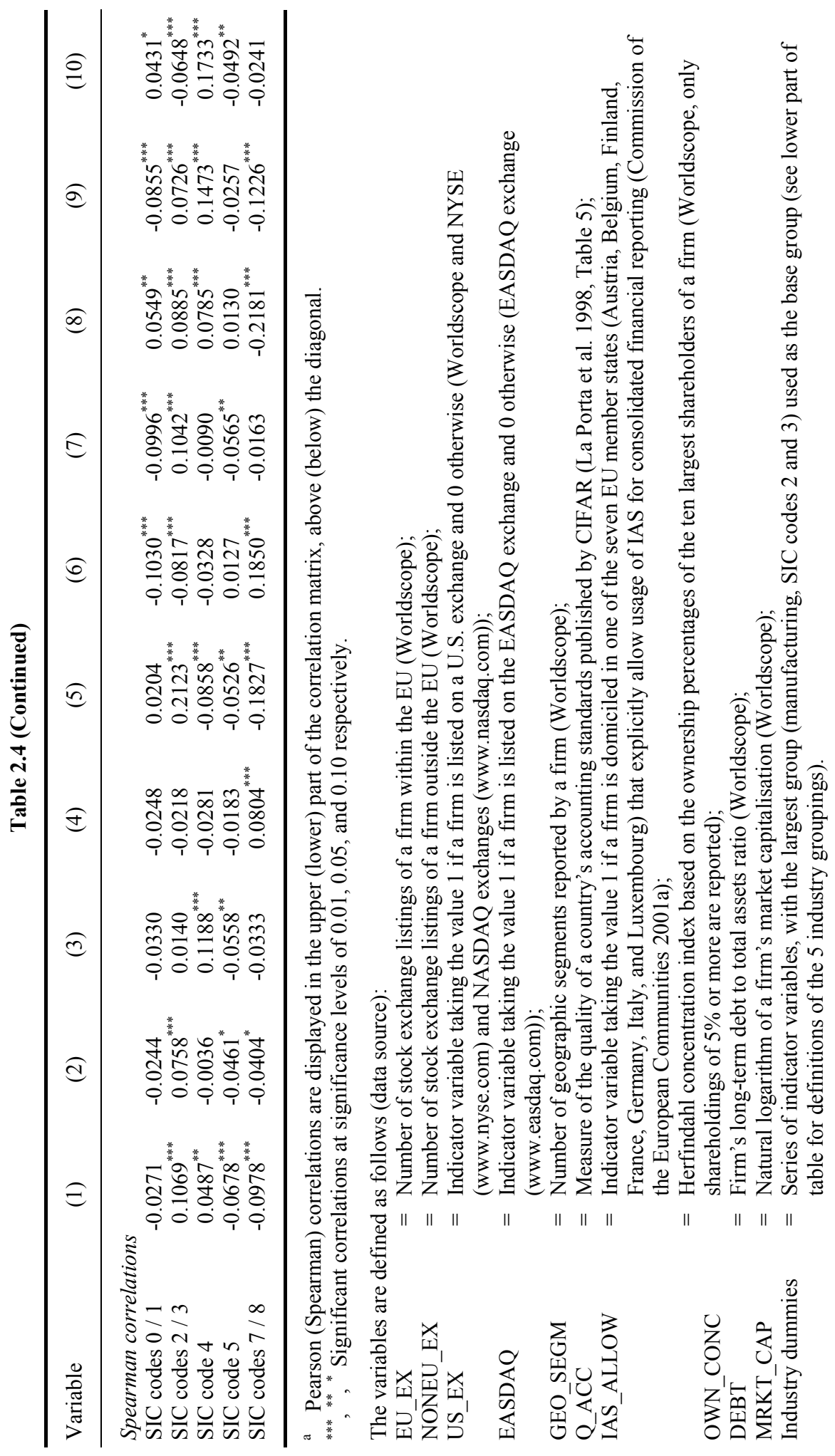


Table 2.5

Logistic regression analysis of determinants of non-local GAAP adoption

\begin{tabular}{|c|c|c|c|c|}
\hline \multirow[b]{2}{*}{ Independent variable } & \multirow[b]{2}{*}{$\begin{array}{l}\text { Expected } \\
\text { sign }\end{array}$} & \multirow{2}{*}{$\begin{array}{c}\text { Full sample } \\
\begin{array}{c}\text { Coefficient } \\
\left(\text { Wald } \chi^{2}\right)\end{array}\end{array}$} & \multirow{2}{*}{$\begin{array}{c}\text { Model (b) } \\
\text { Excluding firms } \\
\text { listed in the U.S. } \\
\text { and on the } \\
\begin{array}{c}\text { EASDAQ } \\
\text { exchange }\end{array} \\
\begin{array}{c}\text { Coefficient } \\
\left(\text { Wald } \chi^{2}\right)\end{array}\end{array}$} & \multirow{2}{*}{$\begin{array}{l}\text { Model (c) } \\
\text { Excluding firms } \\
\text { from countries } \\
\text { where IAS is not } \\
\text { allowed as an } \\
\text { alternative to } \\
\text { local GAAP } \\
\text { Coefficient } \\
\left(\text { Wald } \chi^{2}\right)\end{array}$} \\
\hline & & & & \\
\hline Intercept & & $\begin{array}{l}-0.7768 \\
(0.61)\end{array}$ & $\begin{array}{l}-0.4887 \\
(0.19)\end{array}$ & $\begin{array}{c}3.6036 \\
(4.57)^{++}\end{array}$ \\
\hline EU_EX & + & $\begin{array}{l}0.0895 \\
(0.29)\end{array}$ & $\begin{array}{l}0.1154 \\
(0.35)\end{array}$ & $\begin{array}{l}0.1001 \\
(0.29)\end{array}$ \\
\hline NONEU_EX & + & $\begin{array}{l}-0.2138 \\
(0.45)\end{array}$ & $\begin{array}{l}-0.0905 \\
(0.07)\end{array}$ & $\begin{array}{l}-0.1598 \\
(0.22)\end{array}$ \\
\hline US_EX & + & $\begin{array}{l}0.9461 \\
(6.70)^{* * *}\end{array}$ & - & $\begin{array}{l}0.5448 \\
(1.32)\end{array}$ \\
\hline EASDAQ & + & $\begin{array}{c}3.3459 \\
(33.56)^{* * *}\end{array}$ & - & $\begin{array}{c}3.0156 \\
(22.65)^{* * * *}\end{array}$ \\
\hline GEO_SEGM & + & $\begin{array}{c}0.1925 \\
(15.79)^{* * *}\end{array}$ & $\begin{array}{c}0.1976 \\
(12.90)^{* * *}\end{array}$ & $\begin{array}{c}0.1905 \\
(10.38)^{* * *}\end{array}$ \\
\hline Q_ACC & - & $\begin{array}{c}-0.0793 \\
(26.07)^{* * *}\end{array}$ & $\begin{array}{l}-0.0945 \\
(26.08)^{* * *}\end{array}$ & $\begin{array}{l}-0.1321 \\
(24.73)^{* * *}\end{array}$ \\
\hline IAS_ALLOW & + & $\begin{array}{c}1.0277 \\
(13.82)^{* * *}\end{array}$ & $\begin{array}{c}1.4257 \\
(15.54)^{* * * *}\end{array}$ & - \\
\hline OWN_CONC & - & $\begin{array}{l}-0.1405 \\
(0.09)\end{array}$ & $\begin{array}{l}-0.1089 \\
(0.05)\end{array}$ & $\begin{array}{l}-0.1097 \\
(0.05)\end{array}$ \\
\hline DEBT & - & $\begin{array}{l}-0.1925 \\
(0.04)\end{array}$ & $\begin{array}{l}-0.2846 \\
(0.08)\end{array}$ & $\begin{array}{l}-0.6687 \\
(0.36)\end{array}$ \\
\hline MRKT_CAP & + & $\begin{array}{c}0.2831 \\
(18.74)^{* * *}\end{array}$ & $\begin{array}{c}0.3194 \\
(18.89)^{* * * *}\end{array}$ & $\begin{array}{c}0.2994 \\
(15.15)^{* * * *}\end{array}$ \\
\hline Industry dummies ${ }^{\mathrm{a}}$ & & $\begin{array}{l}\mathrm{N} / \mathrm{A} \\
4.93\end{array}$ & $\begin{array}{l}\mathrm{N} / \mathrm{A} \\
5.26\end{array}$ & $\begin{array}{l}\mathrm{N} / \mathrm{A} \\
4.23\end{array}$ \\
\hline Likelihood ratio $\chi^{2}$ & & $174.78^{+++}$ & $123.43^{+++}$ & $130.43^{+++}$ \\
\hline $\begin{array}{ll}\text { Number of } & \text { Non- } \\
\text { observations: } & \text { Loca }\end{array}$ & $\begin{array}{l}\text { Ial GAAP } \\
\text { IAAP }\end{array}$ & $\begin{array}{c}114 \\
1,679 \\
1,793\end{array}$ & $\begin{array}{c}85 \\
1,615 \\
1,700\end{array}$ & $\begin{array}{c}91 \\
1,048 \\
1,139\end{array}$ \\
\hline
\end{tabular}

a Industry effects are tested by testing the joint significance of four industry dummies compared to the base group.

${ }^{* * *},{ }^{* *},{ }^{*}$ Significantly different from zero (one-sided) at significance levels of $0.01,0.05$, and 0.10 respectively.

${ }^{+++},{ }^{++},{ }^{+}$Significantly different from zero (two-sided) at significance levels of $0.01,0.05$, and 0.10 respectively. 
debt to total assets ratio, MRKT_CAP is the natural logarithm of a firm's market capitalization, industry membership is represented by a series of indicator variables (INDUSTRY), with the largest group (manufacturing) used as the base group.

The results of estimating equation (2.1), displayed in Table 2.5 (model a), show that the choice to adopt non-local instead of local GAAP is significantly positively related to (1) having a listing in the U.S., (2) being listed on the EASDAQ exchange, (3) operating in more geographic segments, (4) being domiciled in a country that has accounting standards of lower quality, (5) being domiciled in a country that explicitly allows IAS as an alternative to local GAAP, and (6) being larger as measured by market capitalization. It is remarkable that a firm's number of (EU and non-EU) exchange listings is not significantly positively related to non-local GAAP adoption, a finding contrary to the univariate analysis. Also, the combined effect of the industry dummies is insignificant.

The high correlations between some of the independent variables could cause a multicollinearity problem in the regression analyses. To determine the extent of multicollinearity in the regression analysis, I compute the variance inflation factor (VIF) for each variable in equation (2.1). Because these values (not reported) do not

Table 2.5 (Continued)

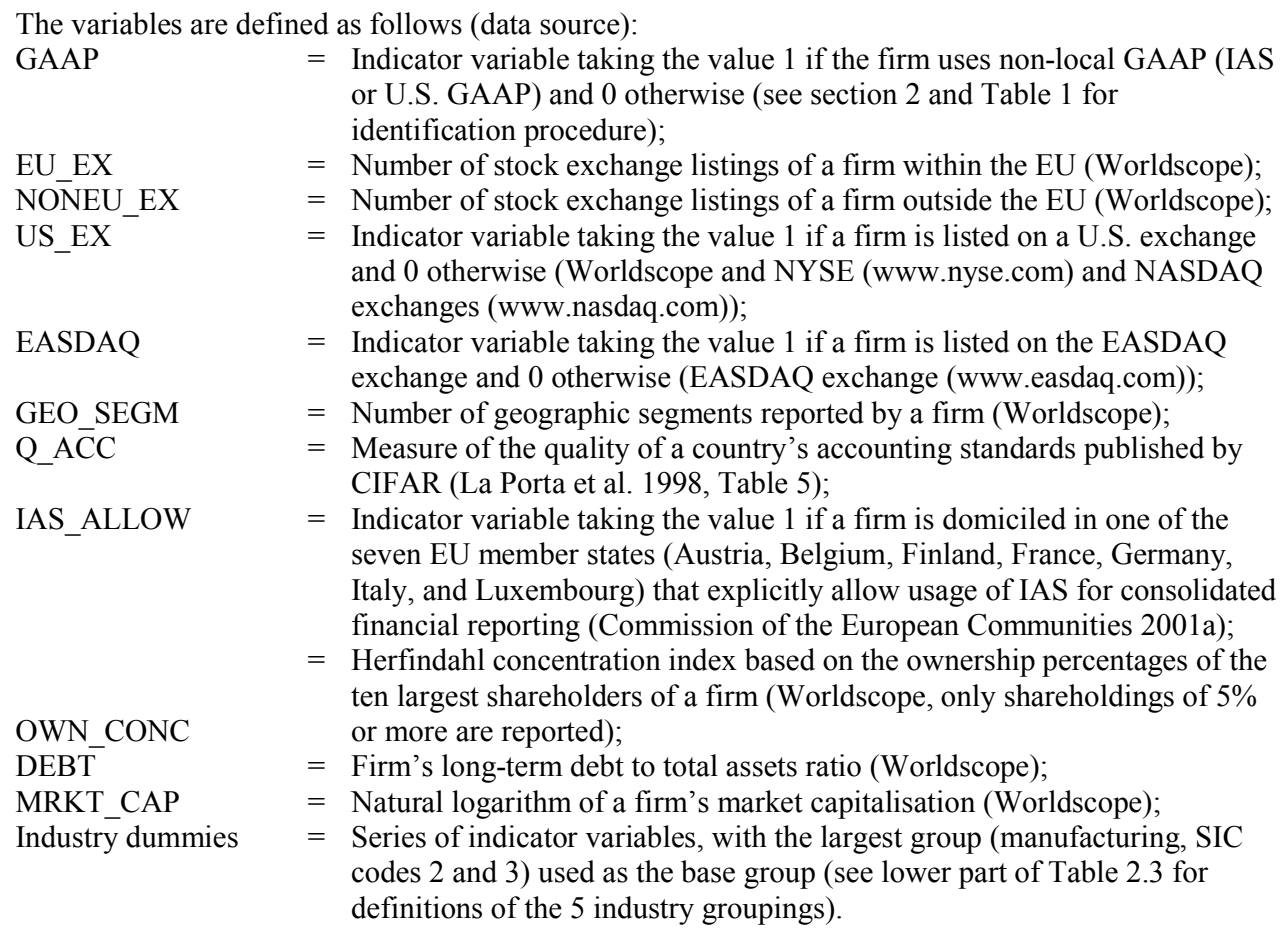


exceed 2 for any independent variable, I conclude that multicollinearity does not present a severe problem in my analysis. In addition, in an attempt to solve the problem of high correlation between $E U_{-} E X$ and $N O N E U_{-} E X$, I sum these variables and re-estimate equation (2.1). The conclusions reported earlier are not affected, because I find an insignificant negative coefficient on the summation variable. I also tried using the natural logarithm of sales as an alternative for the size measure $\left(M R K T \_C A P\right)$. This variable has similarly high correlations with the other independent variables and substitution of this variable in equation (2.1) does not materially change the results reported earlier.

As explained in section 2, firms listed on the EASDAQ exchange or a U.S. exchange have strong incentives to report according to non-local GAAP. To examine whether inclusion of these firms is driving the results, I re-estimate equation (2.1) without firms listed on the EASDAQ exchange or a U.S. exchange. Dropping these firms from the analysis does not materially change any of the other results, as can be seen from Table 2.5 (model b). To control for possible impediments to non-local GAAP adoption, I drop all firms domiciled in countries where IAS is not explicitly allowed as an alternative to local GAAP from the analysis. Again, the results do not change materially (see Table 2.5 , model c), only the positive effect of having a listing in the U.S. disappears. To control for unknown barriers to non-local GAAP adoption, I re-estimate equation (2.1) on a restricted sample including only firms from countries where I observe a relatively large number of firms (more than 10) adopting non-local GAAP (Austria, France, Germany, and The Netherlands). Besides turning the joint effect of the industry controls significant, the logistic regression outcome (not reported) leaves the results reported earlier qualitatively unchanged.

Earlier I argued that financial statement enforcement quality in a country might influence a firm's decision to adopt non-local GAAP. Firms may try to overcome weaknesses in their domestic enforcement system by adopting IAS or U.S. GAAP, thereby committing to high quality financial reporting. The Fédération des Experts Comptables Européens (2001) concludes that the enforcement of financial reporting standards for listed firms is largely comparable across Europe. The main differences between European countries relate to institutional oversight systems. A number of EU countries do not have a specific institutional oversight system for financial reporting standards in place. ${ }^{14}$ To test whether the absence of an institutional oversight system increases the likelihood that firms choose non-local GAAP for financial reporting, I add an indicator variable to regression equation (2.1), which takes the value of 1 if an institutional oversight system for financial reporting is in place and 0 otherwise. The results (not tabulated) from estimating equation (2.1) with the indicator variable included, confirm that the absence of an institutional oversight system leads to a higher probability of non-local GAAP adoption. ${ }^{15}$ This could suggest that EU firms adopt 
non-local GAAP to overcome low quality domestic enforcement of financial reporting. An alternative explanation is that the costs of adopting of non-local GAAP are lower in countries with weak enforcement of financial reporting. This would mean that adoption in these countries does not represent such a strong commitment to increased financial reporting quality as in countries where enforcement is of higher quality.

Because listed EU firms are required to use IAS from 2005 on, it is especially interesting to see what factors determine the adoption of IAS versus local GAAP. By identifying firms that experience net benefits from IAS adoption, I am essentially identifying the firms that the EC is benefiting by the new regulation. After the new regulation enters into effect, these firms are more likely to comply with the regulation. Enforcement can therefore be targeted at firms for whom IAS adoption is not expected to be beneficial. Unreported results indicate that the determinants of IAS adoption are similar to the determinants of non-local GAAP adoption in general. ${ }^{16}$

\subsection{Consequences of non-local GAAP adoption}

In section 3, I study the net benefits of non-local GAAP adoption by documenting firm characteristics that are related to non-local GAAP adoption. The underlying economic assumption is that firms switch to IAS or U.S. GAAP because the benefits outweigh the costs. Therefore, by identifying the characteristics of firms that use non-local GAAP, I am providing indirect evidence of the net benefits of adoption. In this section I attempt to measure benefits of adoption directly.

Prior literature finds some evidence indicating that firms experience capital market benefits from adopting non-local GAAP. Auer (1996) finds that earnings announcements of Swiss firms using IAS convey more information to the market than announcements of firms using Swiss GAAP, but that there is no significant difference with financial statements based on EC-Directives. Furthermore, Swiss firms switching to IAS experience a significant change in stock return volatility (Auer 1998). However, the evidence is mixed, because for some firms volatility decreases, whereas for others it decreases. Leuz and Verrecchia (2000) find evidence suggesting that the information asymmetry component of the cost of capital for German firms adopting IAS or U.S. GAAP decreases, by documenting a reduction in the bid-ask spread and an increase in trading volume. However, they do not find any impact on volatility. Ashbaugh and Pincus (2001) find that analyst forecast errors decrease after firms adopt IAS. I build on these studies by examining cost of capital effects directly as well as providing results on some other information asymmetry proxies for listed EU firms. ${ }^{17}$

As stated earlier, I view non-local GAAP adoption as a voluntary commitment to increased disclosure. If this makes financial statements more informative to capital market participants, I expect information asymmetry in the market to decrease (Bartov 
and Bodnar 1996; Leuz and Verrecchia 2000). Lower information asymmetry is expected to lead to a lower cost of equity capital (Botosan 1997) and increased information intermediation by financial analysts (Healy and Palepu 2001). Other studies (Krishnaswami and Subramaniam 1999; Leuz 2003) have used dispersion in analyst earnings forecasts and stock return volatility as proxies for information asymmetry, because they indicate uncertainty about the financial position of a firm. If firms are providing more standardized financial information by using non-local GAAP, I expect capital market participants' beliefs to be more homogeneous, causing lower forecast dispersion and stock return volatility.

\subsubsection{Cost of capital}

I hypothesize that adoption of non-local GAAP reduces a firm's cost of equity capital, because the increased disclosure and stricter measurement rules of non-local GAAP (Ashbaugh 2001; Ashbaugh and Pincus 2001) are expected to reduce information asymmetry, which leads to lower transaction costs and increased market liquidity. Also, non-diversifiable estimation risk associated with making investment decisions is reduced, which reduces the cost of capital (Botosan 1997; Botosan and Plumlee 2002).

Estimates of the cost of capital are calculated for the groups of non-local GAAP adopters and non-adopters separately, using the method by Easton et al. (2002). This method can be used to simultaneously determine cost of capital and growth rate estimates for groups of firms. Guay et al. (2003) show that cost of capital estimates from implied cost of capital approaches are highly dependent on terminal value assumptions (i.e., forecast period and assumed abnormal earnings growth rate). An important advantage of the Easton et al. (2002) method is that I do not need to explicitly define a growth rate of abnormal earnings beyond the forecast horizon. I obtain cost of capital and growth rate estimates, by fitting the following regression equation for the local and non-local GAAP group separately:

$$
X / B=\gamma_{0}+\gamma_{1} M / B+\varepsilon
$$

where $M / B$ is the firm's market-to-book ratio at fiscal yearend (from Worldscope) and $X / B$ is cumulative forecasted cum-dividend earnings (earnings forecasts are provided by $\mathrm{I} / \mathrm{B} / \mathrm{E} / \mathrm{S}$ ) for the next four fiscal years divided by book value per share at fiscal yearend. ${ }^{18}$ The coefficient estimates from equation (2.2) allow me to calculate the cost of capital $(r)$ and the growth rate of abnormal earnings $(g)$ for local and non-local GAAP adopters (Easton et al. 2002).

$$
\begin{aligned}
& \gamma_{0}=(1+g)^{4}-1 \\
& \gamma 1=(1+r)^{4}-(1+g)^{4}
\end{aligned}
$$


From equations (2.3) and (2.4), estimates of $r$ and $g$ can be derived as follows:

$$
\begin{aligned}
& g=\sqrt[4]{\left(1+\gamma_{0}\right)}-1 \\
& r=\sqrt[4]{\left(1+\gamma_{0}+\gamma_{1}\right)}-1
\end{aligned}
$$

Because $\mathrm{I}$ require $\mathrm{I} / \mathrm{B} / \mathrm{E} / \mathrm{S}$ analyst earnings forecasts, among others, for estimating equation (2.2), the number of observations with sufficient data available drops considerably, compared to the earlier analyses. I employ a matched sample design, because I cannot readily include any control variables in equation (2.2) and I want to control for known determinants of the cost of capital. This means that for each non-local GAAP user with sufficient data available for the analysis (77 firms, 55 IAS and 22 U.S. GAAP users), I find a matching non-local GAAP user. I control for a firm's country of domicile, because the risk free rate of return differs internationally, which could lead to country effects in the cost of capital estimates. To rule out any risk-based explanations for differences in cost of capital, I also control for beta and size (Botosan 1997). Furthermore, I control for the likelihood of non-local GAAP adoption, because I expect firms with a low likelihood of adoption that use non-local GAAP to benefit less from adoption than firms with a high likelihood, i.e., I expect the net benefits to non-local GAAP adoption to be higher for firms with a higher likelihood of adoption. I measure the likelihood of adoption by the fitted values from the adoption choice regression (equation (2.1)). Specifically the sampling procedure is as follows: for each non-local GAAP user I find a local GAAP match from the same country of domicile with the smallest combined difference in terms of beta ${ }^{19}$, size (measured by the natural logarithm of market capitalization) and likelihood of adoption. $^{20}$ This means that the same local GAAP user can be the best match for more than one non-local GAAP firm. In this case I include this firm more than once in the local GAAP sample.

As shown in Table 2.6 (Panel A) I find no evidence of any direct benefits of non-local GAAP adoption in terms of lower cost of capital. The cost of capital for the non-local GAAP adopters is even (insignificantly) higher than for the group of local GAAP users. Potential explanations for this finding are that firms need time to learn to comply with all requirements of IAS or U.S. GAAP in their financial statements or that investors and analysts need to time to learn to interpret these financial statements. $^{21}$ To examine these explanations, I divide the group of non-local GAAP adopters into firms that have been using IAS or U.S. GAAP for two or more years ('early' adopters, with adoption before fiscal year 1998) and firms that only recently started using non-local GAAP ('late' adopters, with adoption in fiscal year 1998 or 1999). ${ }^{22}$ Because I do not have adoption dates for all firms, the sample of non-local GAAP adopters is reduced to 27 'early' and 36 'late' adopters. The results, displayed 
in Table 2.6, Panels B and C, show that both 'early' and 'late' non-local GAAP adopters have an insignificantly higher cost of capital than their local GAAP control group. However, the difference between the group of non-local and local GAAP users is smaller for firms that have been using non-local GAAP longer. This finding provides weak support for the idea that information asymmetry only gradually decreases after non-local GAAP adoption.

Table 2.6

Analysis of cost of capital differences between non-local and local GAAP users

\begin{tabular}{|c|c|c|}
\hline \multicolumn{3}{|l|}{ Panel A Full sample } \\
\hline \multirow[b]{2}{*}{ Independent variable } & Non-local GAAP & Local GAAP \\
\hline & $\begin{array}{c}\text { Coefficient } \\
\text { (t-statistic) }\end{array}$ & $\begin{array}{l}\text { Coefficient } \\
\text { (t-statistic) }\end{array}$ \\
\hline Intercept & $\begin{array}{c}0.5479 \\
(5.80)^{+++}\end{array}$ & $\begin{array}{c}0.3966 \\
(3.25)^{+++}\end{array}$ \\
\hline $\mathrm{M} / \mathrm{B}$ & $\begin{array}{c}0.0890 \\
(3.51)^{+++}\end{array}$ & $\begin{array}{c}0.1394 \\
(2.91)^{+++}\end{array}$ \\
\hline Adjusted $\mathrm{R}^{2}$ & $20.48 \%$ & $35.33 \%$ \\
\hline Number of observations & 77 & 77 \\
\hline Cost of equity capital (r) ${ }^{\mathrm{a}}$ & $13.11 \%$ & $11.32 \%$ \\
\hline Growth rate of abnormal earnings $(\mathrm{g})^{\mathrm{a}}$ & $11.54 \%$ & $8.71 \%$ \\
\hline
\end{tabular}

Panel B Sample of 'early' non-local GAAP adopters

\begin{tabular}{|c|c|c|}
\hline & Non-local GAAP & Local GAAP \\
\hline Independent variable & $\begin{array}{l}\text { Coefficient } \\
\text { (t-statistic) }\end{array}$ & $\begin{array}{l}\text { Coefficient } \\
\text { (t-statistic) }\end{array}$ \\
\hline Intercept & $\begin{array}{c}0.4796 \\
(3.82)^{+++}\end{array}$ & $\begin{array}{c}0.3338 \\
(2.06)^{+}\end{array}$ \\
\hline $\mathrm{M} / \mathrm{B}$ & $\begin{array}{c}0.1044 \\
(2.19)^{++}\end{array}$ & $\begin{array}{c}0.1754 \\
(2.37)^{++}\end{array}$ \\
\hline Adjusted $\mathrm{R}^{2}$ & $27.93 \%$ & $39.11 \%$ \\
\hline Number of observations & 27 & 27 \\
\hline Cost of equity capital (r) ${ }^{\mathrm{a}}$ & $12.18 \%$ & $10.84 \%$ \\
\hline Growth rate of abnormal earnings $(\mathrm{g})^{\mathrm{a}}$ & $10.29 \%$ & $7.47 \%$ \\
\hline
\end{tabular}


Table 2.6 (Continued)

Panel C Sample of 'late' non-local GAAP adopters

\begin{tabular}{|c|c|c|}
\hline & on-local GAAP & Local GAAP \\
\hline Independent variable & $\begin{array}{l}\text { Coefficient } \\
\text { (t-statistic) }\end{array}$ & $\begin{array}{c}\text { Coefficient } \\
\text { (t-statistic) }\end{array}$ \\
\hline Intercept & $\begin{array}{c}0.4329 \\
(6.32)^{+++}\end{array}$ & $\begin{array}{l}0.2603 \\
(1.44)\end{array}$ \\
\hline $\mathrm{M} / \mathrm{B}$ & $\begin{array}{c}0.0941 \\
(4.80)^{+++}\end{array}$ & $\begin{array}{c}0.1680 \\
(2.42)^{++}\end{array}$ \\
\hline Adjusted $\mathrm{R}^{2}$ & $47.64 \%$ & $49.26 \%$ \\
\hline Number of observations & 36 & 36 \\
\hline Cost of equity capital (r) ${ }^{a}$ & $11.16 \%$ & $9.32 \%$ \\
\hline Growth rate of abnormal earnings $(\mathrm{g})^{\mathrm{a}}$ & $9.41 \%$ & $5.95 \%$ \\
\hline
\end{tabular}

a Estimates of the cost of equity capital $(r)$ and the growth rate of abnormal earnings $(g)$ are calculated from the coefficient estimates as follows (Easton et al. 2002): $g=\left(1+\gamma_{0}\right)^{1 / 4}-1$; $r=\left(1+\gamma_{0}+\gamma_{1}\right)^{1 / 4}-1$. t-statistics are calculated using White (1980) adjusted standard errors, because the error term is heteroskedastic (see Easton et al. 2002, footnote 11). The differences in cost of capital between non-local and local GAAP users are not statistically significant in panels A, $\mathrm{B}$, and C. Furthermore, the difference in cost of capital between non-local and local GAAP users for 'early' adopters (panel B) is not significantly different from this difference for 'late' adopters (panel C).

${ }^{+++},{ }^{++},{ }^{+}$Significantly different from zero (two-sided) at significance levels of $0.01,0.05$, and 0.10 respectively.

The variables are defined as follows (data source):
$\mathrm{X}$
$=$ Cumulative forecasted cum-dividend earnings per share for the next four fiscal years measured six months after fiscal yearend (I/B/E/S);
$\mathrm{B}=$ Firm's book value per share at fiscal yearend (Worldscope);
$\mathrm{M} / \mathrm{B}$
$=$ Firm's market-to-book ratio at fiscal yearend (Worldscope).

\subsubsection{Analyst following}

If financial analysts are primarily information intermediaries, an increase in disclosure is expected to lead to an increase in investor base, and consequently an increase in a firm's analysts following, because of increased demand for analyst services by investors. $^{23}$ The supply of analyst services is also likely to increase, because information acquisition costs are lower if a firm voluntarily provides additional information. However, if analyst services are competing with firm-provided disclosures, an increase in disclosure may actually lead to a decrease in analyst following (Lang and Lundholm 1996). Evidence by Lang and Lundholm (1996), who find that analyst following increases with disclosure, supports the view that analysts are information intermediaries. Because I view usage of non-local GAAP as a 
voluntary increase in disclosure, I expect a positive association between non-local GAAP adoption and analyst following. Moreover, because of the enhanced international comparability of IAS or U.S. GAAP financial statements, I also expect IAS and U.S. GAAP adopters to attract an increasing number of international analysts. Ashbaugh and Pincus (2001) document an increase in analyst following after firms adopt IAS. At the country level, Chang et al. (2000) find that analyst activity depends on international institutional factors. They find that analyst following is significantly higher in countries with higher stock market development and higher quality accounting standards. Lang et al. $(2003,2004)$ find that non-U.S. firms traded in the U.S. attract a higher number of analysts. Furthermore, I expect firms listed on more exchanges and larger firms to attract higher levels of analyst following, because of their greater public exposure. Firms with high stock return volatility are expected to be followed less, because of the higher uncertainty involved in forecasting future performance (Lang and Lundholm 1996; Lang et al. 2003, 2004). To control for these known determinants of analyst following, I include controls for stock market development, quality of accounting standards, exchange listings, size, and stock return volatility in the analysis. I also include the industry controls introduced in equation (2.1). I examine the impact of non-local GAAP usage on analyst following by estimating the following regression equation:

$$
\begin{aligned}
& \text { FOLLOWING }=\beta_{0}+\beta_{1} G A A P+\beta_{2} E U_{-} E X+\beta_{3} N O N E U_{-} E X+\beta_{4} U S_{-} E X+ \\
& \beta_{5} Q_{-} A C C+\beta_{6} S T M R K{ }_{-} D E V+\beta_{7} V O L A T I L I T Y+\beta_{8} M R K T_{-} C A P+ \\
& \sum_{k=1}^{4} \kappa_{k} I N D U S T R Y_{k}+\varepsilon
\end{aligned}
$$

where FOLLOWING is the natural logarithm of one plus the number of analysts issuing forecasts for next year's earnings outstanding six months after fiscal yearend (from $\mathrm{I} / \mathrm{B} / \mathrm{E} / \mathrm{S}$ ), GAAP is a dummy variable taking the value 1 if a firm uses non-local GAAP and 0 otherwise, $E U_{-} E X, N O N E U_{-} E X, U S_{-} E X, Q_{-} A C C, M R K T_{-} C A P$, and the industry dummies are as defined in section 3, stock market development (STMRKT_DEV) is the ratio of a country's stock market capitalization to GDP ${ }^{24}$ in 1999, and return volatility (VOLATILITY) is the standard deviation of abnormal daily stock returns (from Datastream) over a firm's current fiscal year. ${ }^{25}$ Because I require data on analyst following and return volatility, the number of observations with sufficient data available drops compared to the analysis in Table 2.5. I have sufficient data on 94 non-local GAAP (66 IAS and 28 U.S. GAAP) users and 1321 local GAAP users.

An univariate analysis of differences (Wilcoxon two-sample test, not tabulated) between the groups of non-local and local GAAP users reveals that analyst following is significantly higher for firms using IAS or U.S. GAAP (z-statistic 6.92, significant 
Table 2.7

Analysis of differences in analyst following between non-local and local GAAP users

\begin{tabular}{|c|c|c|c|}
\hline \multirow[b]{2}{*}{ Independent variable } & \multirow[b]{2}{*}{$\begin{array}{l}\text { Expected } \\
\text { sign }\end{array}$} & \multirow{2}{*}{$\begin{array}{l}\text { Full sample } \\
\begin{array}{l}\text { Coefficient } \\
\text { (t-statistic) }\end{array}\end{array}$} & \multirow{2}{*}{$\begin{array}{c}\begin{array}{c}\text { Sample including only } \\
\text { non-local GAAP adopters } \\
\text { with known adoption date }\end{array} \\
\begin{array}{c}\text { Coefficient } \\
\text { (t-statistic) }\end{array}\end{array}$} \\
\hline & & & \\
\hline \multicolumn{2}{|l|}{ Intercept } & $\begin{array}{l}-1.2112 \\
(-5.40)^{+++}\end{array}$ & $\begin{array}{l}-1.1701 \\
(-5.22)^{+++}\end{array}$ \\
\hline GAAP & + & $\begin{array}{l}0.3580 \\
(3.83)^{* * *}\end{array}$ & $\begin{array}{l}0.1947 \\
(1.53)\end{array}$ \\
\hline $\mathrm{EARLY} \times \mathrm{GAAP}^{\mathrm{a}}$ & & - & $\begin{array}{l}0.2519 \\
(1.26)\end{array}$ \\
\hline EU_EX & + & $\begin{array}{l}0.0036 \\
(0.07)\end{array}$ & $\begin{array}{l}0.0058 \\
(0.11)\end{array}$ \\
\hline NONEU_EX & + & $\begin{array}{l}0.0419 \\
(0.42)\end{array}$ & $\begin{array}{l}0.0473 \\
(0.47)\end{array}$ \\
\hline US_EX & + & $\begin{array}{l}0.0063 \\
(0.05)\end{array}$ & $\begin{array}{l}-0.0315 \\
(-0.25)\end{array}$ \\
\hline Q_ACC & + & $\begin{array}{c}0.0154 \\
(4.76)^{* * *}\end{array}$ & $\begin{array}{l}0.0148 \\
(4.58)^{* * * *}\end{array}$ \\
\hline STMRKT_DEV & + & $\begin{array}{c}0.1342 \\
(3.02)^{* * *}\end{array}$ & $\begin{array}{l}0.1380 \\
(3.10)^{* * * *}\end{array}$ \\
\hline VOLATILTY & - & $\begin{array}{l}-8.0485 \\
(-4.94)^{* * *}\end{array}$ & $\begin{array}{l}-8.6392 \\
(-5.28)^{* * *}\end{array}$ \\
\hline MRKT_CAP & + & $\begin{array}{c}0.4276 \\
(31.52)^{* * * *}\end{array}$ & $\begin{array}{c}0.4284 \\
(31.47)^{* * *}\end{array}$ \\
\hline \multicolumn{2}{|l|}{ Industry dummies $^{\mathrm{b}}$} & $\begin{array}{c}\mathrm{N} / \mathrm{A} \\
(2.34)^{+}\end{array}$ & $\begin{array}{c}\text { N/A } \\
(1.95)\end{array}$ \\
\hline \multicolumn{2}{|l|}{ Adjusted $\mathrm{R}^{2}$} & $52.84 \%$ & $52.87 \%$ \\
\hline $\begin{array}{l}\text { Number of } \\
\text { observations: }\end{array}$ & $\begin{array}{l}\text { GAAP } \\
\text { AP }\end{array}$ & $\begin{array}{c}94 \\
1,321 \\
1,415\end{array}$ & $\begin{array}{c}76 \\
1,321 \\
1,397\end{array}$ \\
\hline
\end{tabular}

a In the second model, the effect for early adopters, represented by the sum of the coefficients on $G A A P$ and $E A R L Y \times G A A P$, is significantly different from zero at the 0.01 significance level.

b Industry effects are tested by testing the joint significance of four industry dummies compared to the base group.

${ }^{* * *},{ }^{* *},{ }^{*}$ Significantly different from zero (one-sided) at significance levels of $0.01,0.05$, and 0.10 respectively.

${ }^{+++},++{ }^{+}$Significantly different from zero (two-sided) at significance levels of $0.01,0.05$, and 0.10 respectively.

(Continued on next page) 


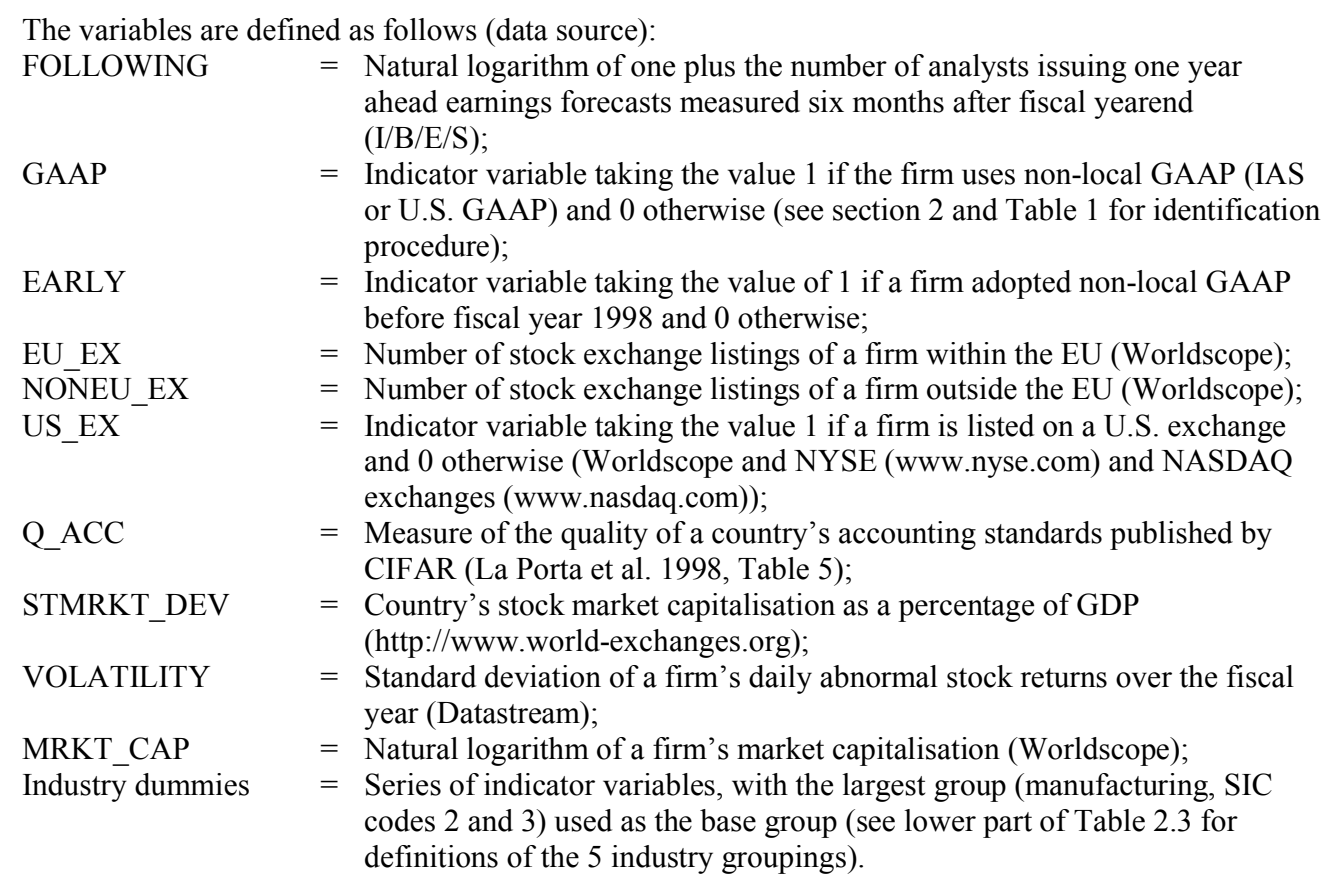

at the $1 \%$ level, two-sided). ${ }^{26}$ Firms using non-local GAAP are followed by an average of 27.27 analysts, whereas this figure is 13.37 for firms using local GAAP. ${ }^{27}$ As can be seen from the regression analysis in Table 2.7, I find that non-local GAAP usage has a significantly positive effect on analyst following. Except for the listing variables, the control variables have the expected signs and are statistically significant. To test whether there is a difference in analyst following between 'early' and 'late' non-local GAAP adopters, I add an interaction term, EARLY $\times G A A P$, to equation (2.7), where $E A R L Y$ is an indicator variable that takes the value 1 if a firm adopted IAS or U.S. GAAP before fiscal year 1998, and 0 otherwise. For estimating this modified version of equation (2.7), I have enough data on 29 'early' adopters and 47 'late' adopters. The results, also shown Table 2.7, indicate that the positive effect of non-local GAAP adoption on analyst following is mainly due to 'early' adopters, because the effect for 'late' adopters (given by the coefficient on $G A A P$ ) is insignificantly positive and the effect for 'early' adopters (given by sum of the coefficients on GAAP and EARLY $\times$ $G A A P)$ is significantly positive. This provides further support for the idea that the benefits of non-local GAAP adoption take some time to fully materialize. 


\subsubsection{Uncertainty}

Adoption of IAS or U.S. GAAP typically reduces the choice of accounting measurement rules that can be used compared to local GAAP (Ashbaugh 2001; Ashbaugh and Pincus 2001). I expect adoption of non-local GAAP to lead to more homogeneous beliefs about a firm, because differences in interpretation of accounting information by analysts and investors are reduced. However, the relative inexperience of some analysts and investors with IAS or U.S. GAAP may initially make financial statement information harder to interpret and cause forecast dispersion and stock return volatility to increase. Moreover, if adoption of non-local GAAP reduces firms' opportunities for income smoothing, earnings may become more volatile and less predictable (Chang et al. 2000), leading to more heterogeneous beliefs. I measure the effect on analyst and investor beliefs by examining differences in abnormal stock return volatility and dispersion in analyst earnings forecasts between non-local and local GAAP users, using the following regression equations:

$$
\begin{aligned}
& \text { DISPERSION }=\beta_{0}+\beta_{1} \text { GAAP }+\beta_{2} \text { FOLLOWING }+\beta_{3} \text { VOLATILITY }+ \\
& \beta_{4} Q_{-} A C C+\beta_{5} \text { MRKT_CAP }+\sum_{k=1}^{4} \kappa_{k} I N D U S T R Y_{k}+\varepsilon \\
& \text { VOLATILITY }=\beta_{0}+\beta_{1} G A A P+\beta_{2} Q_{-} A C C+\beta_{3} M R K T \_C A P+ \\
& \sum_{k=1}^{4} \kappa_{k} I N D U S T R Y_{k}+\varepsilon
\end{aligned}
$$

where DISPERSION is defined as the standard deviation deflated by the absolute value of the mean one-year ahead analyst earnings forecast outstanding six months after fiscal yearend (from $\mathrm{I} / \mathrm{B} / \mathrm{E} / \mathrm{S}$ ) and all other variables are as defined earlier. In equation (2.8) I control for the number of analysts following a firm (FOLLOWING), because analysts' information processing and disclosure may be an input to decisions by investors and other analysts, leading to more homogeneous beliefs and a reduction in forecast dispersion. I also control for abnormal stock return volatility (VOLATILITY), because I expect analysts' earnings forecasts to be more homogeneous for less volatile stocks. In both equations (2.8) and (2.9) I control for quality of accounting standards at the country level $\left(Q_{-} A C C\right)$ and firm size $(M R K T+C A P)$. I expect the quality of financial reporting to influence uncertainty about a firm among analysts and investors. On the one hand, high quality financial reporting is expected to reduce uncertainty because better information about the firm is available. On the other hand, because higher quality accounting standards are typically stricter and allow less measurement alternatives, opportunities for income smoothing are reduced, which could make forecasting of future performance more difficult. I expect uncertainty regarding large firms to be lower, because large firms have higher public exposure, resulting in more 
Table 2.8

Analysis of differences in uncertainty between non-local and local GAAP users

Panel A Analyst forecast dispersion (DISPERSION) as dependent variable

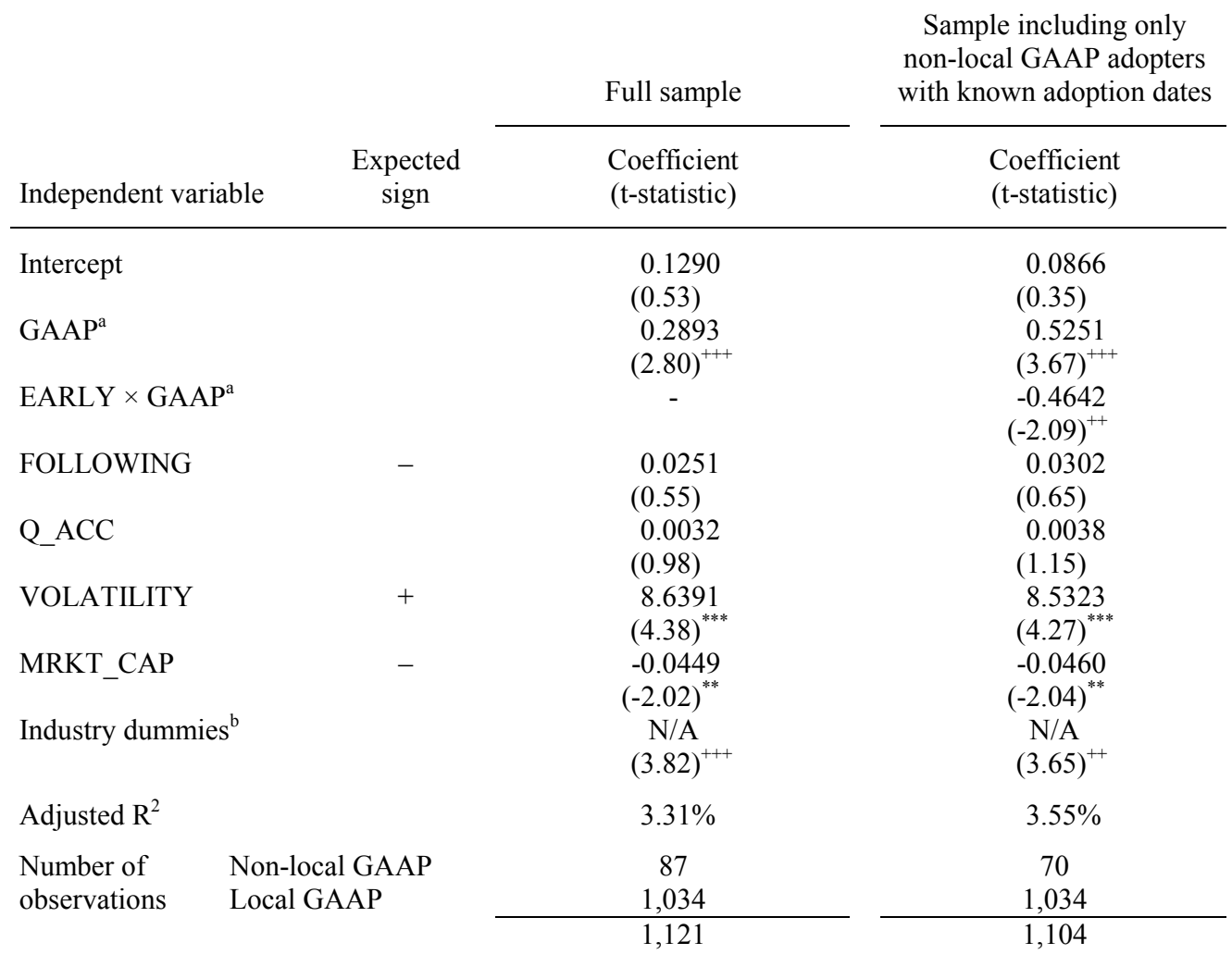

Panel B Stock return volatility (VOLATILITY) as dependent variable

\begin{tabular}{|c|c|c|c|}
\hline & & Full sample & $\begin{array}{c}\text { Sample including only } \\
\text { non-local GAAP adopters } \\
\text { with known adoption dates }\end{array}$ \\
\hline Independent variable & $\begin{array}{l}\text { Expected } \\
\text { sign }\end{array}$ & $\begin{array}{l}\text { Coefficient } \\
\text { (t-statistic) }\end{array}$ & $\begin{array}{l}\text { Coefficient } \\
\text { (t-statistic) }\end{array}$ \\
\hline Intercept & & $\begin{array}{c}0.0313 \\
(8.51)^{+++}\end{array}$ & $\begin{array}{c}0.0313 \\
(9.64)^{+++}\end{array}$ \\
\hline GAAP $^{\mathrm{a}}$ & & $\begin{array}{l}0.0014 \\
(0.94)\end{array}$ & $\begin{array}{l}0.0000 \\
(0.01)\end{array}$ \\
\hline $\mathrm{EARLY} \times \mathrm{GAAP}^{\mathrm{a}}$ & & - & $\begin{array}{l}0.0019 \\
(0.58)\end{array}$ \\
\hline
\end{tabular}

(Continued on next page) 
Table 2.8 (Continued)

\begin{tabular}{lccc}
\hline & Full sample & $\begin{array}{c}\text { Sample including only } \\
\text { non-local GAAP adopters } \\
\text { with known adoption dates }\end{array}$ \\
Independent variable & $\begin{array}{c}\text { Expected } \\
\text { sign }\end{array}$ & $\begin{array}{c}\text { Coefficient } \\
\text { (t-statistic) }\end{array}$ & $\begin{array}{c}\text { Coefficient } \\
\text { (t-statistic) }\end{array}$ \\
\hline Q_ACC & & 0.0000 & 0.0000 \\
MRKT_CAP & $(0.48)$ & $(0.45)$ \\
Industry dummies & & -0.0013 & -0.0013 \\
Adjusted ${ }^{2}$ & $(-6.66)^{* * *}$ & $(-6.47)^{* * *}$ \\
Number of & Non-local GAAP & $(12.99)^{+++}$ & $(13.53)^{+++}$ \\
observations: & Local GAAP & $6.61 \%$ & $6.56 \%$ \\
& & 94 & 76 \\
& 1,321 & 1,321 \\
\hline
\end{tabular}

a The effect for early adopters, represented by the sum of the coefficients on GAAP and $E A R L Y \times G A A P$, is not significantly different from zero.

b Industry effects are tested by testing the joint significance of four industry dummies compared to the base group.

${ }^{* * *},{ }^{* *},{ }^{*}$ Significantly different from zero (one-sided) at significance levels of $0.01,0.05$, and 0.10 respectively.

${ }^{+++},++,{ }^{+}$Significantly different from zero (two-sided) at significance levels of $0.01,0.05$, and 0.10 respectively.

The variables are defined as follows (data source):

DISPERSION $=$ Standard deviation deflated by the absolute value of the mean of one year ahead analyst earnings forecasts measured six months after fiscal yearend $(\mathrm{I} / \mathrm{B} / \mathrm{E} / \mathrm{S})$;

VOLATILITY $=$ Standard deviation of a firm's daily abnormal stock returns over the fiscal year (Datastream);

GAAP $\quad=$ Indicator variable taking the value 1 if the firm uses non-local GAAP (IAS or U.S. GAAP) and 0 otherwise (see section 2 and Table 1 for identification procedure);

EARLY

$=$ Indicator variable taking the value of 1 if a firm adopted non-local GAAP before fiscal year 1998 and 0 otherwise;

FOLLOWING $=$ Natural logarithm of one plus the number of analysts issuing one year ahead earnings forecasts measured six months after fiscal yearend $(\mathrm{I} / \mathrm{B} / \mathrm{E} / \mathrm{S})$;

Q_ACC

$=$ Measure of the quality of a country's accounting standards published by CIFAR (La Porta et al. 1998, Table 5);

MRKT_CAP

$=$ Natural logarithm of a firm's market capitalisation (Worldscope);

Industry dummies

$=$ Series of indicator variables, with the largest group (manufacturing, SIC codes 2 and 3 ) used as the base group (see lower part of Table 2.3 for definitions of the 5 industry groupings). 
information being publicly available. I also control for possible differences in uncertainty across industries, by including the same set of industry dummies as in earlier analyses. For estimating regression equation (2.8) (equation (2.9)), I have enough data on 87 (94) non-local GAAP users (59 (66) IAS and 28 (28) U.S. GAAP) and 1036 (1321) local GAAP users.

The results of a Wilcoxon two-sample test (not tabulated) indicate that there is no significant difference in forecast dispersion (z-statistic 0.71) or abnormal stock return volatility (z-statistic -0.53 ) between the group of non-local and local GAAP users. $^{28,29}$ The results from estimating regression equations (2.8) and (2.9), displayed in Panels A and B of Table 2.8, suggest that uncertainty is larger for firms using non-local GAAP, because forecast dispersion (abnormal stock return volatility) is significantly (insignificantly) positively associated with non-local GAAP usage. I also find that forecast dispersion increases with abnormal stock return volatility. Furthermore, I find the expected negative effect of firm size in both regressions. Industry membership also appears to influence uncertainty. The finding that uncertainty is higher for firms using non-local GAAP than for firms using local GAAP is consistent with non-local GAAP offering fewer opportunities for income smoothing or unfamiliarity of capital market participants with IAS or U.S. GAAP. If the results are due to unfamiliarity with non-local GAAP, I expect to observe the positive effect of non-local GAAP usage on uncertainty to be more pronounced for firms that have only recently started using IAS or U.S. GAAP ('late' adopters). To explicitly examine this explanation, I add an interaction term, $E A R L Y \times G A A P$, to regression equations (2.8) and (2.9). For estimating this modified version of equation (2.8) (equation (2.9)), I have enough data for 27 (29) 'early' adopters and 43 (47) 'late' adopters. The results, also displayed in Panels A and B of Table 2.8, show that only 'late' non-local GAAP adopters have significantly higher forecast dispersion than local GAAP users; 'early' adopters do not differ significantly from local GAAP users. My earlier (insignificant) findings regarding abnormal return volatility remain unaffected.

\subsubsection{Selection bias}

Because firms choose their reporting standards conditional on the expected net benefits in terms of reduced information asymmetry, the analysis could be influenced by self-selection bias (Leuz and Verrecchia 2000; Leuz 2003). This could mean that the coefficient on GAAP in equations (2.7), (2.8), and (2.9) is overstated. ${ }^{30}$ I examine the impact of possible self-selection bias using the approach by Leuz and Verrecchia (2000), i.e., I estimate a two-stage model to measure 'treatment effects'. First, I estimate a probit model to predict the choice to adopt non-local GAAP (using the same variables to explain adoption as in equation (2.1)). ${ }^{31}$ Subsequently, I estimate the effect 
of adoption on information asymmetry controlling for possible self-selection bias. The results (not tabulated) indicate that the inferences obtained earlier remain qualitatively unchanged. However, I no longer find that forecast dispersion is higher for firms using non-local GAAP, i.e., the coefficient on GAAP in equation (2.8) is no longer significant. $^{32}$

\subsection{Discussion and concluding remarks}

I study the determinants and consequences of voluntary non-local GAAP adoption. I find that the rate of adoption of non-local GAAP by non-financial firms domiciled and listed in the EU in 1999 is relatively low. Apparently, voluntary adoption of IAS or U.S. GAAP brings no net economic benefits for a large majority of firms. However, I find that adopters of non-local GAAP have some common characteristics that discriminate them from non-adopters. Firms that use non-local GAAP are more likely to be listed on a U.S. exchange or the EASDAQ exchange, have more geographically dispersed operations, and are larger on average than firms using local GAAP. I also find that firms adopting non-local GAAP are more likely to be domiciled in countries with lower quality financial reporting and in countries where IAS is explicitly allowed as an alternative to local GAAP.

Besides documenting the characteristics of firms that decide to adopt non-local GAAP, I also study the consequences of adoption. Specifically, I test whether firms using IAS or U.S. GAAP experience a lower level of information asymmetry, by examining several proxies for information asymmetry. I fail to find evidence of a lower cost of capital for adopters. However, firms adopting IAS or U.S. GAAP, and especially 'early' adopters, attract more financial analysts. I also find that forecast dispersion is higher for firms that recently started using non-local GAAP ('late' adopters). I do not find a difference in forecast dispersion between 'early' non-local GAAP adopters and firms using local GAAP. Furthermore, there is no significant difference in stock return volatility between non-local and local GAAP users.

These findings suggest that non-local GAAP adopters share common characteristics and that, although they are experiencing benefits by increased public exposure in capital markets, the reductions in information asymmetry they experience appear to be small. One reason may be that investors and analysts need time to learn to understand the changes in a firm's financial reporting brought about by the switch to non-local GAAP or that firms need time to learn to fully comply with the new set of accounting standards. Another explanation for the lack of compelling evidence of lower information asymmetry for non-local GAAP users could be that accounting quality is not primarily determined by accounting standards, but that firms' reporting incentives play a more important role (Ball et al. 2003). In my setting this would mean 
that the choice of accounting standards, non-local versus local GAAP, is not determining the quality of financial statements and the resulting level of information asymmetry, but that firms' incentives to report informatively are more important.

The finding that net benefits of voluntary non-local GAAP adoption seem to be positive for only a small fraction of listed EU firms, coupled with the apparent lack of any quantifiable benefits is surprising, and certainly informative, considering the obligation for listed EU firms to use IAS (or International Financial Reporting Standards, IFRS, as future standards by the IASB are called) from 2005 on. Because I examine a time period before the European Commission formally announced this regulation, firms using IAS can be seen as voluntary adopters of this regulation who expect IAS usage to be beneficial. The firms that voluntarily use IAS are therefore representative of the types of firms that the EC is benefiting by the new regulation. From this perspective this research sheds some light on the decision function of the EC. The study also provides some insights into the social aspects of IAS adoption in the EU, by showing how the net benefits of IAS adoption are distributed across EU countries (Table 2.2). Furthermore, it seems reasonable to believe that firms not experiencing net benefits from adoption will have an incentive to not fully comply with the regulation, once in place. Therefore, the results can also help the EC and other regulators in deciding where to put emphasis in their enforcement efforts, once the IAS regulation will be effective.

The EC motivates the regulation by referring to the enhanced international comparability and transparency of financial statements and improved access to international capital markets resulting from IAS usage. I fail to find strong evidence of lower information asymmetry, a much cited benefit of more transparent financial reporting, for non-local GAAP adopters. If this finding is due to the second-order effect of accounting standards in determining accounting quality (i.e., firms' reporting incentives are more important), this would mean that the mandatory usage of IAS from 2005 on would not automatically lead to the anticipated benefits in terms of more transparency and lower information asymmetry, without a simultaneous change in firms' reporting incentives. However, the findings do suggest that benefits of adoption are larger for 'early' adopters than for 'late' adopters, which provides some support for the view of the EC that standardization of financial reporting would be needlessly lengthy if left up to financial markets and that in the meantime competition between different standards would not lead to improvements in terms of transparency and comparability. On the whole, it remains an open question whether mandatory, as opposed to voluntary adoption of IAS by all listed EU firms from 2005 on will bring the desired benefits and lead to a quantifiable reduction in information asymmetry for all firms. 


\section{Notes}

1 For an overview of listing requirements of EU stock exchanges, see Haller (2002).

2 Private communication with Stefano Zambon confirmed this. His research shows that only three Italian firms comply fully with IAS.

3 I would like to thank Paul Pacter of the IASC for providing the list that was no longer available from the IASC web site.

4 To be included, the auditor's report and summary of accounting policies, or footnotes must state that the financial statements comply with IAS without qualification (IASC 2001).

5 Not necessarily IAS, however no more specific data was available.

6 Item number GF66: Accounting standard - Note (ASTD). Again, no more specific data was available.

7 There was considerable overlap between the different data sources.

8 I also excluded a small number of firms classified as SIC code 9.

9 The inclusion of firms domiciled in the United Kingdom in my regression analyses (I do not have data on the quality of Irish accounting standards) does not materially influence the results.

10 See Maddala (2001, section 8.3) or, for a discussion of methodological issues in using in an accounting context, see Zmijewski (1984), Palepu (1986), and Maddala (1991).

11 Mutual recognition in this context means that EU firms listing on a stock exchange in the EU can use their local GAAP to draw up their financial statements.

12 The measure developed by Ashbaugh (2001) is not available for Austria, Greece, and Italy, whereas the CIFAR score is only unavailable for Luxembourg.

13 Although this score was constructed based on 1990 annual reports, I still expect the measure to reflect differences in accounting disclosures across countries, because regulation and practice only change gradually.

14 EU countries without any institutional oversight systems for financial reporting standards are: Austria, Finland, Germany, Ireland, Luxembourg, and the Netherlands (Ireland and Luxembourg are not included in the analyses). The report does not analyze the enforcement mechanisms in Greece, which forces me to exclude Greek firms from this sensitivity analysis.

15 The coefficient on the indicator variable is statistically significant (1\% level, one-sided). Inclusion of this variable leaves the results reported earlier qualitatively unchanged.

16 I estimate the logistic regression equation (1) including only firms using IAS or local GAAP (i.e., excluding U.S. GAAP users), with $I A S$ as the dependent variable (an indicator variable that takes the value 1 if a firm uses IAS and 0 otherwise) and without the dummy variable indicating a U.S. listing (US_EX).

17 In contrast to Auer (1998) and Ashbaugh and Pincus (2001) I employ a cross-sectional design to study the consequences of non-local GAAP adoption, mainly because of data availability constraints. After contacting the 114 firms using non-local GAAP examined in section 3, I was able to obtain the date of first usage for 92 firms. However, many of these firms did not switch to nonlocal GAAP but were using (or started using) IAS or U.S. GAAP at the time of the IPO. Consequently, for many firms I do not have pre-adoption data available. Furthermore, Leuz and Verrecchia (2000) point out that, based on an event study (around the switch to non-local GAAP), it is hard to separate the effect on information asymmetry from the news effect (the revision in capital market participants' expectations about future firm performance). Therefore, Leuz and 
Verrecchia perform time-series analysis only as a consistency check for their cross-sectional findings.

${ }^{18}$ I use earnings forecasts outstanding 6 months after fiscal yearend to allow the publication of (possible first-time) non-local GAAP annual reports to affect my information asymmetry proxies. When forecasts for the next four years are not available, I use the forecasted earnings growth rate from $\mathrm{I} / \mathrm{B} / \mathrm{E} / \mathrm{S}$ or the growth rate implicit in forecasts that are available to calculate the missing forecasts. I exclude observations that have negative cumulative four year earnings forecasts.

19 I estimate beta by using daily return observations (from Datastream, at least 150 observations required) over the firm's fiscal year for which I analyze the accounting standard choice.

20 Specifically, I minimize the Euclidean distance between local and non-local GAAP users per country based on standardized measures of beta, market capitalization, and probability of adoption (the fitted value per firm from regression equation (1)).

${ }^{21}$ I thank one of the anonymous reviewers for suggesting this possibility.

22 I contacted the 114 firms using non-local GAAP included in the determinants analysis and asked when they started using IAS or U.S. GAAP. In this way I was able to obtain the date of first usage of non-local GAAP for 92 firms. Data availability constraints reduce the number of observations in the various consequences analyses even further.

23 An alternative would be to directly examine changes in a firm's investor base. I did not perform this analysis because, based on my data, it is hard to come up with a proxy for investor base.

24 Data is available at the statistics section of the web site of the World Federation of Exchanges (http://www.world-exchanges.org).

25 At least 150 daily return observations are required.

26 Wilcoxon two-sample tests for differences between the groups of non-local and local GAAP users for the independent variables appearing in equation (7) reveal differences comparable to those in Table 2.3, suggesting that the reduction in observations has not changed the composition of the sample significantly. The level of stock market development (STMRKTDEV) is significantly lower ( $1 \%$ level, two-sided) for non-local GAAP than for local GAAP users. Furthermore, there is no significant difference in abnormal stock return volatility (VOLATILITY) between the groups of nonlocal and local GAAP users.

27 The mean natural logarithm of one plus analyst following (FOLLOWING) for the group of nonlocal (local) GAAP users is 2.92 (2.02), the standard deviation is 1.09 (1.21), and the median is 3.11 (2.08). For the full sample (non-local and local GAAP users), the mean is 2.08, the standard deviation is 1.22 , and the median is 2.08 .

28 Wilcoxon two-sample tests for differences between the groups of non-local and local GAAP users for the independent variables appearing in equations (8) and (9) confirm earlier findings (also see Table 2.3 and note 26 ).

29 The mean forecast dispersion (DISPERSION) for the group of non-local (local) GAAP users is 0.63 (0.39), the standard deviation is $1.87(0.78)$, and the median is $0.26(0.25)$. For the full sample (non-local and local GAAP users), the mean is 0.41 , the standard deviation is 0.91 , and the median is 0.25 . The mean stock return volatility (VOLATILITY) for the group of non-local (local) GAAP users is $0.03(0.03)$, the standard deviation is $0.01(0.01)$, and the median is $0.02(0.02)$. For the full sample (non-local and local GAAP users), the mean is 0.03 , the standard deviation is 0.01 , and the median is 0.02 . 
${ }^{30}$ In the analysis of cost of capital differences between non-local and local GAAP users, selfselection bias is less of an issue, because I match local GAAP users to non-local GAAP users on the estimated benefit of adoption, i.e., the fitted values from equation (1), among others (also see note 20 ).

31 The results (not tabulated) from estimating the probit model are comparable to the results from the logistic regression model (see Table 2.5, model a).

32 Specifically, I find that the coefficient on GAAP remains positive and statistically significant in equation (7). In equation (8), the effect of non-local GAAP adoption on forecast dispersion is no longer statistically significant. Controlling for possible self-selection bias does not influence the results obtained from estimating equation (9), i.e., I do not find an effect of non-local GAAP usage on stock return volatility. Furthermore, the coefficients on the control variables included in equations (7), (8), and (9) remain qualitatively similar. In addition to the two-stage model described in the text, I also use an instrumental variables approach (as described in Leuz and Verrecchia 2003 , footnote 23), with similar results. Note that I do not control for possible self-selection in the equations where I separately measure the effect of early and late adoption of non-local GAAP on my information asymmetry proxies (see Tables 2.7 and 2.8), because this would require explicit modeling of the early versus late adoption choice to avoid self-selection bias. I consider this to be outside of the scope of the paper. 



\section{Chapter 3}

\section{Firm-Level Reporting Incentives and Accounting Properties: Stakeholder- versus Shareholder-Oriented Governance Structures*}

\subsection{Introduction}

Around the world, accounting is going through substantial changes. One of the most apparent current worldwide developments is that accounting regulators mandate firms to report their financial statements in accordance with International Accounting Standards (IAS). Regulators' overriding objective for taking such actions is to improve the usefulness of accounting information for shareholders, as illustrated by the European Union's motivation of its decision to prescribe IAS in the EU:

"This Regulation aims at contributing to the efficient and cost-effective functioning of the capital market. The protection of investors and the maintenance of confidence in the financial markets is also an important aspect of the completion of the internal market in this area." (Regulation (EC) No 1606/2002 of the European Parliament and of the Council.)

Because prior research suggests that changes in accounting regulation do not necessarily imply changes in accounting practices (Ball 2001; Ball et al. 2003), the worldwide move towards shareholder-oriented accounting regulation yields an important research question. Do firm-specific reporting incentives moderate the effect of shareholder-oriented accounting regulation on accounting practices?

In this chapter, I investigate the impact of various corporate governance mechanisms on the properties of firms' accounting information in a country with shareholder-oriented accounting rules that exhibit much resemblance with IAS. The setting of my study, i.e., The Netherlands, is interesting from a corporate governance perspective for several reasons. First, public firms' ownership structures are very diverse and range from majority-owned by one large shareholder to the classic example of a widely-held firm (De Jong et al. 2001). Within the same institutional context, I am therefore able to study firms with diffuse ownership structures, which

\footnotetext{
* This chapter is based on a working paper co-authored with Frank Moers and Erik Peek. I gratefully acknowledge the contribution of Thomson Financial for providing earnings per share forecast data, available through the I/B/E/S - Institutional Brokers Estimate System.
} 
resemble typical U.S. firms, and firms with concentrated ownership, which are common in large parts of the world. Second, unlike many Anglo-Saxon countries, the Dutch corporate law allows public firms to adopt a rich variety of protectionist measures that severely reduce shareholders' intervention power and impair the market for corporate control, such as the issuance of non-voting depository receipts and the use of voting caps. In addition, many firms, but not all, are subject to the so-called structure regime, which grants the Supervisory Board significantly greater power than in non-structure firms, at the expense of shareholders' power. Dutch regulators' main objective for allowing such anti-shareholder, protectionist measures and corporate structures is to reduce the influence of minority shareholders with the intention to isolate firm management from myopic influences and to impose a stakeholder orientation on firm management (SER 1969; Voogd 1989). ${ }^{1}$

The main research question that I address is whether firms' orientation, in terms of shareholder versus stakeholder orientation, affects the properties of their financial reporting. Because Dutch firms can choose to adopt protectionist measures and because the structure regime does not apply to all firms, the governance structures in my sample exhibit sufficient variation to examine the impact of shareholder versus stakeholder orientation on financial reporting, holding other institutional influences constant. In this study, I examine the influence of a firm's corporate governance structure, stakeholder- versus shareholder-oriented, on three characteristics of financial reporting: earnings smoothing, conservatism, and the likelihood of meeting or beating analyst earnings forecasts. I expect that firms with more concentrated ownership, more takeover defense mechanisms in place, and firms subject to the structure regime, i.e., a stakeholder-oriented governance structure, smooth earnings more actively, report more (unconditionally) conservatively, and are less likely to meet or beat analyst expectations than shareholder-oriented firms. My findings are consistent with these expectations.

My study distinguishes itself from prior studies in three important ways. First, to date, single-country studies on the effect of corporate governance on financial reporting have mainly focused on two extreme corporate governance models. That is, most prior studies examine either the U.S. or the U.K. (e.g., Warfield et al. 1995; Vafeas 2000; Beekes et al. 2003), where shareholder rights are well-protected, ownership is widespread, and the market for corporate control is strong, or East Asia (e.g., Ball et al. 2003; Fan and Wong 2002; Yeo et al. 2002), where shareholders are poorly protected and most firms have concentrated ownership structures. A distinctive feature of my research setting is that Dutch firms exhibit clear differences in governance and reporting incentives. In addition, accounting institutions in The Netherlands tend to leave much discretion to the firm because enforcement is weak and tax accounting is formally separate from financial accounting (Alford et al. 1993; 
Ali and Hwang 2000), which ensures that firms do have a choice whether or not to report informatively to shareholders. In this respect, The Netherlands reflects many characteristics of the Continental European and Asian countries that currently introduce or have recently introduced IAS. Many of these countries still have weak enforcement mechanisms and large varieties of governance structures.

Second, the orientation of accounting regulation and firms' governance structures tend to be related across countries, which has led prior researchers to study the influence of orientation on financial reporting by focusing on cross-country differences in reporting systems. For instance, Ali and Hwang (2000), Ball et al. (2000), and Leuz et al. (2003) find that earnings in countries with shareholder-oriented reporting systems are more informative, more conditionally conservative, and less managed, respectively, than in countries with stakeholder-oriented reporting systems. A disadvantage of cross-country research designs is that these are influenced by many confounding factors. For example, countries with stakeholder-oriented reporting systems are often characterized by weak outside investor protection, alignment of financial and tax accounting rules, and low quality accounting regulation and enforcement (Leuz et al. 2003). My focus on one country in which substantial variation in financial reporting orientation exists contrasts with the approaches of Ali and Hwang (2000), Ball et al. (2000), and Leuz et al. (2003) and allows me to isolate the influence of governance on financial reporting from the influence of institutional factors such as accounting regulation.

Third, some prior studies have examined the influence of ownership concentration on financial reporting under shareholder-oriented institutions by comparing public firms and private firms in the U.K. or the U.S. For example, Beatty and Harris (1998) and Beatty et al. (2002) find that managers of public firms use discretion in financial reporting to manage earnings more than managers of private firms, which suggests that managers' reporting decisions are a response to the weight placed on this information by investors. Ball and Shivakumar (2005) directly test the quality of financial reporting across private and public U.K. firms, and find that public firms recognize economic losses on a timelier basis than private firms. The Netherlands provide an interesting setting for studying whether ownership structure influences firms' reporting decisions. Specifically, in contrast with the U.K. or U.S. studies of Ball and Shivakumar (2005), Beatty and Harris (1998), and Beatty et al. (2002), I do not need to rely on data from private firms to study closely held firms, because many Dutch listed companies can be seen as closely held. An advantage of using public firms' data only is that it makes capital market tests of earnings properties possible. I also avoid that possible effects of listing on an exchange, like additional disclosure requirements, intensified public scrutiny, or any other unobservable differences between public and private firms influence my results. 
Finally, my study adds to the findings of Ball et al. (2003), who study financial reporting in four East Asian countries where IAS has been introduced but other reporting incentives, including enforcement, have remained largely unchanged. The authors find that financial reporting has not become comparable to other countries with shareholder-oriented accounting (like e.g. the U.K. or the U.S.). They attribute this finding to the importance of other institutional factors and firm-specific incentives in shaping accounting practice, but cannot explicitly test this. The setting of my study allows powerful tests of the effect of firm's reporting incentives on accounting properties under shareholder-oriented accounting rules.

When extrapolating my results to settings where IAS is introduced, the following caveat of my study should be borne in mind. Although Dutch accounting regulation has the same objective as IAS, Dutch rules do differ from IAS in some areas, such as post-retirement benefits and financial instruments. Despite these differences, I do believe that my results provide relevant insights into the potential impact of IAS introductions on worldwide accounting practices.

The remainder of this chapter is structured as follows. Section two describes the Dutch accounting system, the Dutch corporate governance system, prior literature, and my hypotheses. Section three describes my sample, data, and research design. Section four discusses the empirical tests and the results. Section five concludes with some additional remarks.

\subsection{Background and hypotheses development}

\subsubsection{Dutch accounting regulation}

Dutch financial accounting and tax accounting rules are distinct and the influence of the government on Dutch accounting regulation is limited. Although broad rules concerning the format of financial statements, disclosure, and the valuation of assets, which conform to the EU $4^{\text {th }}$ and $7^{\text {th }}$ Company Law Directive, are incorporated into Dutch Law, detailed accounting rules are set by a private body, i.e., the 'Council for Annual Reporting' (Raad voor de Jaarverslaggeving). The Dutch Council for Annual Reporting issues 'Guidelines for Annual Financial Statements', which are followed by many Dutch publicly listed firms, even though they are not legally binding. The Council's objective in setting Guidelines is similar to the objective of the International Accounting Standards Board (IASB, formerly IASC), i.e., to ensure that publicly listed firms' financial statements provide useful information to shareholders. The idea that the Dutch Guidelines have a shareholder-orientation similar to the IAS is clearly illustrated by the fact that the Dutch Council's Conceptual Framework is a literal translation of the IASB Conceptual Framework for the Preparation and Presentation of Financial Statements, which states that: 
"As investors are providers of risk capital to the enterprise, the provision of financial statements that meet their needs will also meet most of the needs of other users that financial statements can satisfy." (IASB Conceptual Framework, paragraph 10.)

Since the early 1980s, the Council has explicitly integrated the International Accounting Standards into its Guidelines (Buijink and Eken 1999). However, in its effort to seek consensus between the various members of the Council, who are representatives of preparers, users, and auditors of financial statements, the Council has sometimes deviated from the requirements of IAS. Important examples of areas where Dutch Guidelines deviate from IAS at the end of my sample period are that Dutch firms are allowed to write off purchased goodwill against equity immediately on acquisition, Dutch firms have more discretion in setting up provisions, and that IAS 19 (post-retirement benefits) and IAS 39 (financial instruments) are not yet incorporated into the Dutch Guidelines (see e.g., Buijink and Eken 1999; Council for Annual Reporting 1999; Nobes 2000). Because most of the Dutch exceptions to IAS broaden the scope of options, Dutch listed firms are largely able to draw up their financial statement in accordance with IAS, if they desire.

The Dutch Enterprise Chamber, which is a separate section of the Amsterdam Court of Justice, is the only mechanism that passively enforces Dutch accounting rules. Any party with an interest in the financial statements of a firm can file a complaint with the Enterprise Chamber. During my sample period, active enforcement of publicly listed firms' compliance with Dutch accounting rules was absent (Buijink and Eken 1999). The passive character of enforcement in combination with the fact that the Council's Guidelines are not officially backed by the law or endorsed by the stock exchange (Flower 2004, p.80) makes that the enforcement of accounting regulation in The Netherlands is weak. In sum, like IAS, Dutch accounting regulation is not influenced by taxation and has a shareholder-orientation (see also Ali and Hwang 2000; Hung 2001 but Dutch institutions tend to allow much discretion. As a result, the Dutch institutional environment leaves firms the option whether or not to provide informative public financial reporting.

\subsubsection{Dutch corporate governance}

From an international perspective, the corporate governance system in The Netherlands has some unique characteristics. Like some other Continental European countries, the corporate structure of Dutch (public) firms is based on the two-tier board structure, formally separating the decision management and decision control functions. The structure law governs the corporate structure of firms with more than 100 employees and common equity in excess of 13 million Euros. Firms fulfilling these 
criteria are referred to as structure firms. ${ }^{2}$ In structure firms, important rights of common shareholders, namely (1) the authority to appoint and dismiss management and (2) the right to make amendments to the financial statements, are delegated to the Supervisory Board. Furthermore, the Supervisory Board has the right to veto strategic decisions made by the executive board. Members of the Supervisory Board are appointed by co-optation, which means that supervisors appoint their own successors. Furthermore, because Dutch law states that supervisors can only be dismissed by those who appointed them, the Supervisory Board in structure firms is a powerful autonomous body beyond common shareholders' control.

In addition to the firms that do not meet the above size criteria, other firms may be exempt from the structure regime if they are the corporate headquarters of a multinational corporation and employ more than 50 percent of their employees outside The Netherlands. In non-structure firms, the authority of the Supervisory Board is limited to suspending management and disapproving of the financial statements. The authority to appoint and dismiss management and supervisors and the right to amend the financial statements remain with the common shareholders. Approximately 32 percent of my observations come from non-structure firms.

Another characteristic of Dutch corporate governance is the extensive use of various anti-takeover mechanisms (Kabir et al. 1997; De Jong et al. 2001; De Jong 2002). ${ }^{3}$ Mechanisms to limit the power of shareholders are issuing priority shares to a friendly foundation, which retains control over important decisions (adopted by approximately 35 percent of my observations), or limiting the number of votes per shareholder (voting cap, adopted by 3 percent). Another widely used method to limit the voting power of common shareholders is the issuance of depository receipts by an administrative office controlled by the firm (adopted by 30 percent). Holders of depository receipts have all the cash flow rights attached to common shares, but no voting rights. Because the administrative office retains the voting rights attached to the shares, the use of depository receipts significantly reduces the power of common shareholders. The most widely adopted anti-takeover mechanism is the use of preferred defense shares with the same voting rights as common shares (adopted by 60 percent). Once authorized by common shareholders, firm management has the right to issue the preferred shares to a friendly party to avoid a takeover, causing a substantial dilution of common shareholders' voting rights. Kabir et al. (1997) argue that the structure regime, although typically not a choice variable, can also be considered an anti-takeover mechanism, because it limits the power of common shareholders in favor of the Supervisory Board.

A third characteristic of the governance structure in The Netherlands is that in many firms, management or large shareholders hold large parts, or even the majority, of outstanding shares. Whereas such concentrated ownership structures mirror the 
structures that are common in large parts of the world, the ownership structures of several other Dutch listed firms mirror the structures of widely-held firms that are common in the U.S. or the U.K. This gives rise to a great within-country variation in ownership structures (Becht and Röell 1999; Becht and Mayer 2001; De Jong et al. 2001). Institutional ownership is common in The Netherlands, but institutions typically hold only small stakes in Dutch firms (De Jong 2002).

\subsubsection{Hypotheses development}

Financial reporting can have various objectives, such as providing timely information to outside stakeholders, payout determination, or tax determination. In this study, I distinguish two financial reporting systems with different objectives, i.e., stakeholderoriented systems versus shareholder-oriented systems. Following previous studies such as Ali and Hwang (2000) and Ball et al. (2000), I define shareholder-oriented reporting systems as systems whose main objective is to provide a timely and reliable accounting performance measure to shareholders. In contrast, I define stakeholderoriented reporting systems as systems whose main objective is payout determination, i.e., to determine the maximum amount of earnings that can be used for payments to stakeholders such as shareholders and executives, without jeopardizing the firms' financial stability.

The accounting literature identifies several determinants of firms' reporting objectives. One determinant is accounting regulation and enforcement. Ball et al. (2000) argue that the degree of political interference in standard setting differs across countries, yielding cross-country differences in standards' objectives. Specifically, accounting regulation in countries with a high degree of political influence, such as many Continental European countries, tends to focus on payout determination and promote the concept of prudence, which can prohibit firms from providing timely, informative reporting. As argued, the political interference in Dutch standard setting is virtually absent and Dutch accounting regulation has a shareholder-orientation, although the Dutch enforcement environment leaves much discretion to the firm. Hence, Dutch accounting institutions leave firms the option whether or not to provide informative public reporting.

Another determinant of firms' reporting objectives are their governance structures, which create different financial reporting incentives, depending on shareholders' demand for public financial reporting (e.g., Beatty and Harris 1998; Ke et al. 1999; Ball and Shivakumar 2005). In firms with concentrated ownership, characterized by large shareholdings and low share turnover, the importance of financial reporting as a means to resolve information asymmetry is much lower than in widely held firms. Because of their sizeable ownership stakes, large shareholders have 
both the incentives and the means to effectively monitor management (Shleifer and Vishny 1986). Furthermore, in The Netherlands, many large shareholders are directly involved in the monitoring of management through their presence on Supervisory Boards, which reduces their reliance on public financial reporting (Ball and Shivakumar 2005). In contrast, dispersed shareholders in widely-held firms face the problem that other shareholders free ride on their monitoring activities and, consequently, information asymmetry between shareholders and managers is most efficiently resolved by timely public disclosure. Also, shareholders of widely-held firms turn over their shares relatively often compared to closely-held firms' shareholders, which leads to a greater demand for an accurate firm valuation on a continuous basis, translating into greater demand for timely financial reporting.

In The Netherlands, other governance characteristics than ownership concentration can also be associated with firms' reporting objectives. As argued, Dutch firms may use several mechanisms to reduce the intervention power of common shareholders, such as the structure regime or takeover defense measures. The main objective of Dutch regulators to allow the use of such mechanisms is to shield firm management from the influence of minority shareholders and from the threat of hostile takeovers. As such, the structure regime imposes a stakeholder orientation on firms. One example of how this is achieved is that the members of the Supervisory Board of structure firms are appointed by co-optation (i.e., not by the shareholders) and that Dutch law requires those supervisors to act in the interests of all stakeholders. Another example is that in structure firms the Supervisory Board has the right to make amendments to the financial statements and, consequently, has the ultimate authority to determine the amount of profit that is available for dividend payouts, whereas in non-structure firms such authorities devolve to the common shareholders. In addition, because takeover defense measures reduce shareholders' power in the interest of financial stability, firms using such measures implicitly signal their stakeholder orientation.

Based on the above descriptions of Dutch governance structures, I hypothesize that Dutch firms' stakeholder orientation is a positive function of (i) ownership concentration, (ii) being a structure firm and (iii) the number of takeover defense measures in place. I expect that shareholder-oriented and stakeholder-oriented reporting systems produce earnings with different properties. Specifically, I expect that firms having stakeholder-oriented objectives such as payout determination prefer to reduce earnings variability, i.e., smooth earnings, and report (unconditionally) conservatively, i.e., present the worst-case scenario (e.g., Ball et al. 2000; Ball and Shivakumar 2005). The main reason for these reporting preferences is that stable earnings patterns (due to earnings smoothing) and conservative reporting reduce the probability that a firm makes unwarranted payouts to shareholders (dividends) and 
managers (bonuses), which could harm the firm's financial position. To examine the effect of corporate governance on earnings smoothing and conservatism, I therefore test the following hypotheses:

H1: Firms with stakeholder-oriented governance structures smooth earnings to a greater extent than firms with shareholder-oriented governance structures.

H2: Firms with stakeholder-oriented governance structures report more (unconditionally) conservatively than firms with shareholder-oriented governance structures.

I emphasize that my definition of conservatism differs from the definition used by Ball et al. (2000) and Ball and Shivakumar (2005). While these studies examine conditional conservatism, i.e., the timely incorporation of economic losses into accounting income, I focus on unconditional conservatism, i.e., the understatement of assets and revenues and overstatement of liabilities and expenses, unconditional on the presence of economic losses.

In addition to the above reporting strategies, I also expect stakeholder-oriented firms to be less concerned about short-term earnings targets than shareholder-oriented firms. Stein (1988) argues that takeover pressure causes managers to behave myopically because takeover threats provide incentives to managers to increase current earnings in order to avoid being taken over at an (temporarily) undervalued price. The use of anti-takeover mechanisms mitigates these incentives and leads managers to focus more on the long-term viability of the firm than on current profitability. Stein (1988) further argues that one of the factors that cause shares to be (temporarily) undervalued in the first place is the beliefs of shareholders. He distinguishes "patient" from "impatient" shareholders, where impatient (patient) shareholders are defined as those shareholders who are (not) discouraged by low earnings reports and therefore (not) dump their shares as soon as such a report is issued. Impatient shareholders are less likely to be dominant when firms are closely-held than when they are widely-held, which suggests that ownership concentration decreases the probability of (temporary) undervaluation and thus the incentives for myopic behavior.

An important myopic earnings target is meeting or beating analyst earnings forecasts. Degeorge et al. (1999), Matsumoto (2002), and Cheng and Warfield (2005) show that meeting or beating analyst earnings forecasts is an important earnings management threshold. Bartov et al. (2002) document a significant positive stock price reaction to meeting or beating these thresholds. I expect managers of firms with stakeholder-oriented governance structures to be less likely to respond to capital market pressure and less likely to try to meet or beat analyst earnings forecasts. 
H3: Firms with stakeholder-oriented governance structures are less likely to meet or beat analyst earnings forecasts than firms with shareholder-oriented governance structures.

\subsection{Research design}

\subsubsection{Data and sample selection}

The firms included in my sample are Dutch non-financial firms listed on the Amsterdam stock exchange. Using data for the years 1991 to 2000, I obtain 1,176 firm year observations from 173 firms with sufficient data available for the main analyses. Ownership data comes from the WMZ (Disclosure of Major Holdings in Listed Companies Act) register, which is administered by the AFM (The Netherlands Authority for the Financial Markets), the Dutch stock exchange regulatory authority. This register identifies for all listed firms the actual fraction of cash flow rights, as well as voting rights, owned by each shareholder who holds at least 5 percent of the firm's shares (or depository receipts). I manually collected the data on various antitakeover mechanisms and data on whether a firm is subject to the structure regime from the annual reports. Financial statement data come from the REACH database. Stock prices are from Datastream and analyst earnings forecasts are from $\mathrm{I} / \mathrm{B} / \mathrm{E} / \mathrm{S}$.

Table 3.1 shows the descriptive statistics for the sample. The great diversity in ownership structures is apparent, as well as the extensive use of takeover defenses. Preferred shares are the most popular takeover defense (adopted by 60.4 percent of my observations), followed by depository receipts (adopted by 29.7 percent) and priority shares (adopted by 34.6 percent). Statutory limitations on voting rights are relatively uncommon (adopted by 3.3 percent). Furthermore, 68.1 percent of my observations come from firms subject to the structure regime. Firm size, in terms of both total assets and sales, varies substantially across observations. I therefore control for the influence of differences in firm size in my empirical tests.

Table 3.2 shows that ownership concentration is negatively correlated with being subject to the structure regime and the presence of anti-takeover mechanisms, which suggests that these corporate governance mechanisms act as substitutes. Being subject to the structure regime is positively correlated with the number of takeover defense mechanisms in place. Furthermore, the aspects of firms' corporate governance structures that I study are not highly correlated with other firm characteristics, with the exception that structure firms are smaller as measured by total assets and sales. 
Table 3.1

Descriptive statistics $(n=1,176)$

\begin{tabular}{lrrrrr}
\hline Variable & Mean & Standard deviation & Q1 & Median & Q3 \\
\hline Governance variables & & & & & \\
CONCENTRATION & 0.152 & 0.188 & 0.019 & 0.066 & 0.250 \\
Largest shareholder & 0.284 & 0.231 & 0.095 & 0.205 & 0.480 \\
STRUCTURE & 0.681 & - & - & - & - \\
ANTI_TAKEOVER & 1.280 & 0.466 & 1.000 & 1.000 & 2.000 \\
- Priority shares & 0.346 & - & - & - & - \\
- Preferred shares & 0.604 & - & - & - & - \\
- Depository receipts & 0.297 & - & - & - & - \\
- Voting rights limitation & 0.033 & - & - & - & \\
Financial variables & & & & & \\
ASSETS & 1,897 & 6,906 & 61 & 237 & 1,247 \\
SALES & 2,276 & 7,559 & 110 & 390 & 0.104 \\
SSALES & -0.011 & 0.336 & -0.099 & 0.004 & 0.035 \\
ACCR & -0.003 & 0.067 & -0.036 & -0.002 & 0.102 \\
OCF & 0.056 & 0.082 & 0.008 & 0.054 & 0.082 \\
ROA & 0.057 & 0.063 & 0.032 & 0.058 & 0.907 \\
BTM & 0.691 & 0.529 & 0.348 & 0.592 & 0.716 \\
LEVERAGE & 0.617 & 0.142 & 0.528 & 0.633 & \\
\hline
\end{tabular}

The variables are defined as follows:

CONCENTRATION = Herfindahl concentration index of share ownership;

STRUCTURE $\quad=$ Indicator variable equal to 1 if a firm is a structure firm;

ANTI_TAKEOVER $=$ Number of anti-takeover defense mechanisms in place;

Priority shares $\quad=$ Indicator variable equal to 1 if a firm has priority shares outstanding;

Preferred shares $\quad=$ Indicator variable equal to 1 if a firm has the possibility to issue preferred (defense) shares;

Depository receipts $=$ Indicator variable equal to 1 if 50 percent or more of a firm's ordinary share capital consists of depository receipts;

Voting rights $\quad=$ Indicator variable equal to 1 if a firm has a statutory limitation on the

limitation

ASSETS number of votes that can be cast by any single shareholder;

SALES

$\triangle$ SALES

$=$ End-of-year total assets (in millions of Euros);

$=$ Sales (in millions of Euros);

$=$ Change in sales in year $t$, defined as sales in year $t$, scaled by end-of-year total assets, minus sales in year $t-1$, scaled by beginning-of-year total assets;

ACCR

$=$ Working capital accruals in year $t$, defined as non-cash working capital minus provisions in year $t$, scaled by end-of-year total assets, minus noncash working capital minus provisions in year $t-1$, scaled by beginning-ofyear total assets;

OCF

$=$ Operating cash flow in year $t$, defined as net income in year $t$, scaled by end-of-year total assets, minus $\mathrm{ACCR}_{\mathrm{t}}$;

ROA $=$ Return on assets in year $t$, defined as the ratio of net income before extraordinary items in year $t$ to end-of-year total assets;

BTM = Book to market ratio in year $t$, defined as the ratio of end-of-year book value of equity to end-of-year market value of equity;

LEVERAGE $\quad=$ The ratio of end-of-year liabilities to end-of-year total assets.

I report descriptive statistics for $A C C R, O C F, R O A$, and $\triangle S A L E S$ after removing the top and bottom one percent of the corresponding distributions. 


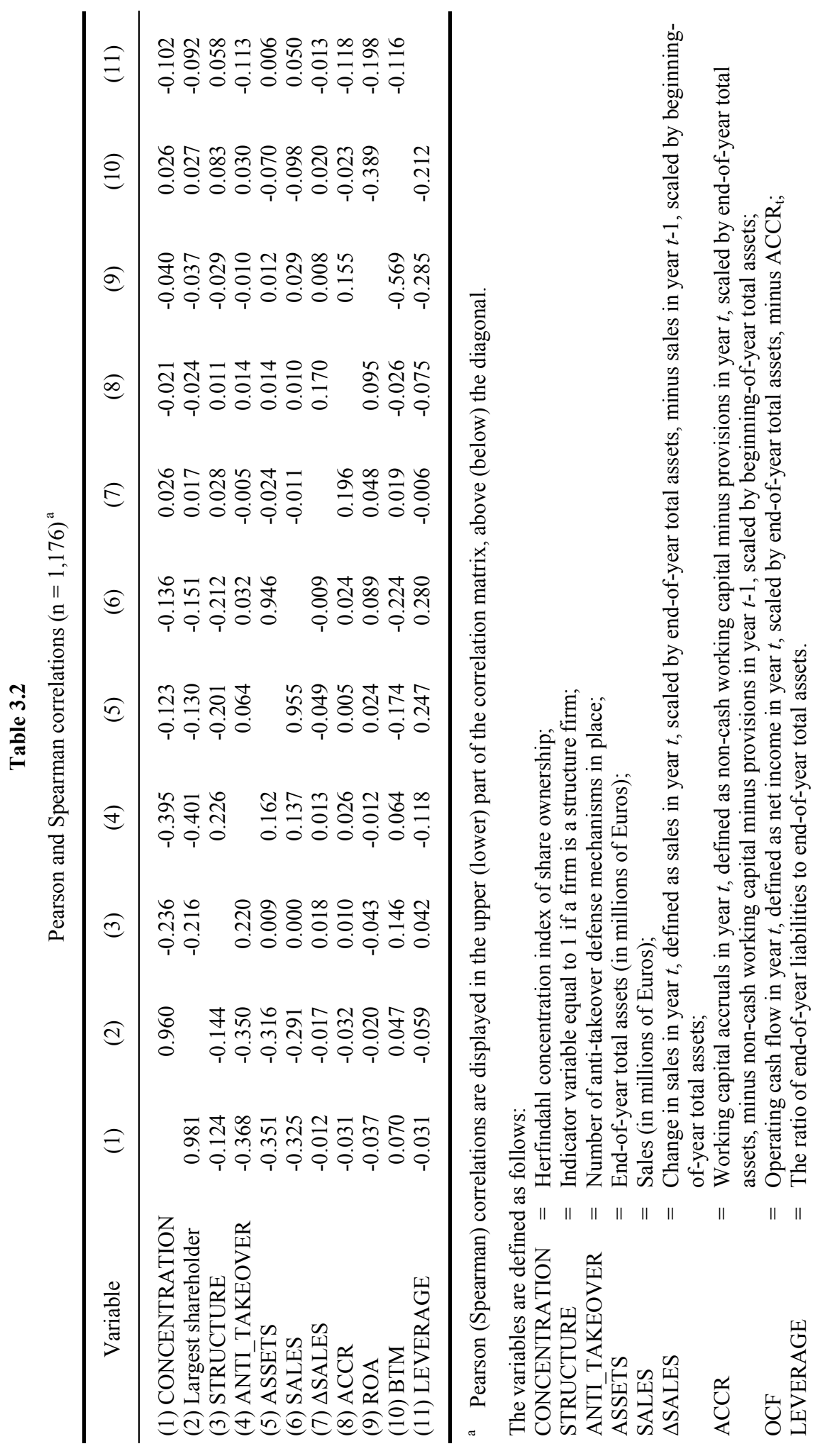




\subsubsection{Smoothing}

In this study, I define earnings smoothing as the negative relation between working capital accruals and current operating cash flows. To some extent, a natural property of accrual accounting is that cash flows and accruals are negatively correlated, because one of the objectives of accrual accounting is to resolve the timing and matching problems of cash flows. However, following Leuz et al. (2003), I interpret a more negative association as evidence that firms use financial reporting discretion to smooth earnings. To test the influence of a firm's governance structure on the tendency to smooth earnings, I therefore estimate the following regression equation:

$$
\begin{aligned}
& \text { ACCR }_{t}=\beta_{0}+\beta_{1} O C F_{t}+\beta_{2} O C F_{t} \times C O N C E N T R A T I O N_{t}+ \\
& \beta_{3} O C F_{t} \times S_{R U C T U R E_{t}}+\beta_{4} O C F_{t} \times A N T I_{-} \text {TAKEOVER }_{t}+\beta_{5} \Delta S A L E S_{t}+ \\
& \beta_{6} S A L E S \_G R O W T H_{t+1}+\beta_{7} O C F_{t} \times S I Z E_{t}+O C F_{t} \times \sum_{k=1}^{8} \kappa_{k} I N D U S T R Y_{k, t}+ \\
& O C F_{t} \times \sum_{l=1}^{9} \lambda_{l} Y E A R_{l, t}+\varepsilon_{t}
\end{aligned}
$$

where:

$A C C R_{t} \quad=$ Working capital accruals in year $t$, defined as non-cash working capital minus provisions in year $t$, scaled by endof-year total assets, minus non-cash working capital minus provisions in year $t$-1, scaled by beginning-of-year total assets;

$O C F_{t} \quad=$ Operating cash flow in year $t$, defined as net income in year $t$, scaled by end-of-year total assets, minus $A C C R_{t}$;

CONCENTRATION ${ }_{t}=$ Herfindahl concentration index of share ownership in year $t$;

$\operatorname{STRUCTURE}_{t} \quad=$ Indicator variable that equals 1 if a firm is a structure firm in year $t$;

ANTI_TAKEOVER ${ }_{t}=$ Number of anti-takeover mechanisms in place in year $t$;

$\triangle S A L E S_{t} \quad=$ Change in sales in year $t$, defined as sales in year $t$, scaled by end-of-year total assets, minus sales in year $t$-1, scaled by beginning-of-year total assets;

SALESGROWTH $H_{t+1}=$ Percentage change in sales from year $t$ to year $t+1$;

$S I Z E_{t} \quad=$ Natural logarithm of end-of-year total assets;

INDUSTRY $\quad=$ Industry dummies based on the industry classification of Barth et al. (1998);

$Y_{t} \quad=$ Year dummies.

Based on my hypothesis that stakeholder-oriented firms smooth earnings more than shareholder-oriented firms, I expect the interaction coefficients on my proxies for the stakeholder orientation of a firm, i.e., CONCENTRATION, STRUCTURE, and 
ANTI_TAKEOVER to be negative. Following the argument that the structure regime could be considered as a takeover defense mechanism (Kabir et al. 1997), I include the summation of STRUCTURE and ANTI_TAKEOVER (labeled PROTECTION) in the first regression. In a second regression, I replace the composite variable with the two separate variables STRUCTURE and ANTI_TAKEOVER.

I include provisions (such as provisions for maintenance or warranty costs) in my accruals measure because prior research finds that Dutch firms use such discretionary provisions in managing earnings (Peek 2004). I include the current year change in sales to control for the non-discretionary component of working capital accruals. Following Dechow et al. (2003), I include next year's percentage change in sales as a control for investments in working capital to facilitate future growth. I further include a proxy for size as an interaction term to control for possible size effects in the accruals-cash flow relation. Finally, I include interactions of $O C F$ with industry and year dummies to control for differences in smoothing behavior across industries or years. My industry classification is similar to the classification used by Barth et al. (1998) and yields 9 different industry classes. ${ }^{5}$ Because OLS residuals of equation (1) could be positively correlated across years, I calculate all t-statistics using heteroskedasticity and autocorrelation consistent standard errors (Newey and West 1987).

\subsubsection{Conservatism}

Following Ahmed et al. (2002), I define conservatism as a persistent difference between market value and book value of equity. To study the impact of governance mechanisms on conservatism, I estimate the following regression equation:

$$
\begin{aligned}
& \text { BTM }_{t}=\beta_{0}+\beta_{1} \text { CONCENTRATION } \\
& \beta_{3}+\beta_{2} \text { STRUCTURE }_{t}+ \\
& \beta_{7} \text { LEVERAGE }_{t}+\beta_{8} \text { DIVIDENDS }_{t}+\beta_{9} \text { STD_ROA }_{t}+\sum_{d=0}^{3} \delta_{d} \text { RET }_{t-d}+ \\
& \sum_{k=1}^{8} \kappa_{k} \text { INDUSTR }_{k, t}+\sum_{l=1}^{9} \lambda_{l} \text { YEAR }_{l, t}+\varepsilon_{t}
\end{aligned}
$$

where:

$B T M_{t}$

$=$ Book to market ratio in year $t$, defined as the ratio of endof-year book value of equity to end-of-year market value of equity;

SALESGROWTH $_{t} \quad=$ Percentage change in sales from year $t-1$ to year $t$;

$R O A_{t} \quad=$ Return on assets in year $t$, defined as the ratio of net income before extraordinary items in year $t$ to end-of-year total 
assets;

LEVERAGE $\quad=$ The ratio of end-of-year ratio of liabilities to end-of-year total assets;

DIVIDENDS $_{t} \quad=$ Dividends declared out of year $t$ net income, scaled by endof-year total assets;

$S T D_{-} R O A_{t} \quad=$ The standard deviation of $R O A_{t}, R O A_{t-1}$, and $R O A_{t-2}$ (if available);

$R E T_{t} \quad=$ Stock return over the twelve month period ending at year $t$ fiscal year-end;

and other variables are as defined before.

Based on the hypothesis that stakeholder-oriented firms report more conservatively than shareholder-oriented firms, I expect the coefficients on my proxies for stakeholder governance structures, CONCENTRATION, STRUCTURE, and ANTI_TAKEOVER to be negative, corresponding to a lower book value of equity relative to market value. Again, I start with a model that includes the summation of STRUCTURE and ANTI_TAKEOVER (labeled PROTECTION) and estimate a second model where I replace the composite variable with the two separate variables STRUCTURE and ANTI_TAKEOVER.

I include the control variables SIZE, ROA, LEVERAGE, DIVIDENDS, and $S T D \_R O A$ because they represent additional explanations for conservatism (Ahmed et al. 2002). Following Beaver and Ryan (2000) and Ahmed et al. (2002), I control for temporary differences between book and market values, caused by lagged accounting recognition, by including current and past returns as proxies for past performance. I again include industry and year dummies to control for industry and year effects. Because OLS residuals of equation (2) could be positively correlated across years, I calculate all t-statistics using heteroskedasticity and autocorrelation consistent standard errors (Newey and West 1987).

Basu (1997) describes an alternative test of conservatism in which earnings are regressed on positive and negative contemporaneous stock returns. In this test, which has been widely applied during the past years, earnings are considered to be more conservative if the coefficient on negative stock returns exceeds the coefficient on positive stock returns, i.e., earnings incorporate economic losses sooner and less gradually than economic profits. I choose not to use this measure of accounting conservatism for two reasons. First, my theory is that stakeholder-oriented firms exhibit more unconditional accounting conservatism than shareholder-oriented firms, whereas Basu's (1997) measure of conservatism focuses on conditional conservatism, i.e., accounting conservatism conditional on the presence of an economic loss. Second, Dietrich et al. (2004) indicate that Basu's (1997) regression is econometrically biased 
and may produce unreliable estimates of conservatism. Dietrich et al. (2004) propose the use of the above market-value method as an alternative for Basu's (1997) method.

\subsubsection{Meeting or beating analyst earnings forecasts}

To examine whether firms with stakeholder-oriented governance structures are less likely to meet or just beat analyst earnings forecasts, I estimate the following regression:

$$
\begin{aligned}
& P(B E A T=1)_{t}=\beta_{0}+\beta_{1} \text { CONCENTRATION }_{t}+\beta_{2} \text { STRUCTURE }_{t}+ \\
& \beta_{3} \text { ANTI_TAKEOVER }+\beta_{4} \text { SIZE }_{t}+\beta_{5} \text { EPS }_{t}+\beta_{6} \Delta \text { EPS }_{t}+\beta_{7} \text { SALESGROWTH }_{t}+ \\
& \beta_{8} \% \text { OLD_FORECAST } t_{t}+\varepsilon_{t}
\end{aligned}
$$

where:

$B E A T_{t} \quad=$ Indicator variable that equals 1 if a firm's EPS meets or exceeds the median analyst earnings forecast outstanding at the firm's year $t$ earnings announcement date;

$E P S_{t} \quad=$ Earnings per share in year $t$, scaled by the end-of-year share price;

$\triangle E P S_{t} \quad=$ The change in earnings per share from year $t-1$ to year $t$, scaled by the end-of-year share price;

$\% O L D_{-} F O R E C A S T_{t}=$ The percentage of forecasts used in calculating the median analyst forecast that has been outstanding for more than ninety days at the year $t$ earnings announcement date;

and other variables are as defined before.

Following my hypothesis that firms with stakeholder-oriented governance structures are less likely to be excessively focused on meeting or beating analyst expectations, I expect the coefficients on my proxies for the stakeholder orientation of a firm (CONCENTRATION, STRUCTURE, and ANTI_TAKEOVER) to be significantly negative. As before, I first estimate a model that includes PROTECTION (the summation of STRUCTURE and ANTI_TAKEOVER). In a second regression, I decompose this variable and include STRUCTURE and ANTI_TAKEOVER separately.

To avoid the possibility that the dependent variable BEAT measures analyst forecast optimism versus pessimism instead of beating the analyst forecast, I take the following precautions. First, in my main analysis I choose a small forecast error interval $(0.01 \%$ of share price at the earnings announcement date) in which I measure $B E A T$, because I expect that a small interval is more likely to measure forecast beating behavior than a large interval, where meeting or beating forecasts could be due to analyst forecast bias. Second, I control for several drivers of analyst forecast bias. Specifically, I control for firm size, because larger firms tend to have less optimistic analyst forecasts (e.g., Matsumoto 2002). I control for unexpected shocks to firms' 
earnings that tend to cause forecast errors by including several measures of current (changes in) performance, i.e., EPS, $\triangle E P S$, and SALESGROWTH (e.g., Eames et al. 2002). ${ }^{6}$ Finally, I control for the percentage of relatively 'old' forecasts used in calculating BEAT by including $\% O L D \_F O R E C A S T$, because older forecasts tend to be more optimistic (e.g., Richardson et al. 2004).

\subsection{Results}

\subsubsection{Smoothing test}

Table 3.3 shows the OLS results of equation (1). The first model in Table 3.3 shows that ownership concentration (CONCENTRATION) negatively affects the relationship between working-capital accruals and contemporaneous cash flows $(\mathrm{p}<0.05$ onetailed). This implies that firms with more concentrated ownership smooth earnings more actively, which is consistent with more stakeholder-oriented financial reporting. The coefficient on the interaction between $O C F$ and PROTECTION, measuring the number of protectionist measures in place (including structure regime), is also significantly negative $(\mathrm{p}<0.01$ one-tailed), which is consistent with the idea that firms that are isolated from intervention by shareholders engage in earnings smoothing to a larger extent.

In a second regression analysis, I decompose the PROTECTION measure into an indicator variable measuring whether a firm is subject to the structure regime

Table 3.3

OLS regression analysis of the influence of stakeholder orientation on the relationship between cash flows and working capital accruals

\begin{tabular}{|c|c|c|c|}
\hline Independent variable & Expected sign & $\begin{array}{l}\text { Coefficient } \\
\text { (t-statistic) }\end{array}$ & $\begin{array}{l}\text { Coefficient } \\
\text { (t-statistic) }\end{array}$ \\
\hline Intercept & $?$ & $\begin{array}{c}0.029 \\
(10.723)^{+++}\end{array}$ & $\begin{array}{c}0.029 \\
(10.680)^{+++}\end{array}$ \\
\hline $\mathrm{OCF}_{\mathrm{t}}$ & - & $\begin{array}{c}-0.175 \\
(-0.842)\end{array}$ & $\begin{array}{c}-0.150 \\
(-0.726)\end{array}$ \\
\hline \multicolumn{4}{|l|}{ Governance variables } \\
\hline $\mathrm{OCF}_{\mathrm{t}} \times \mathrm{CONCENTRATION}_{\mathrm{t}}$ & - & $\begin{array}{c}-0.270 \\
(-2.059)^{* *}\end{array}$ & $\begin{array}{l}-0.267 \\
(-2.047)^{* *}\end{array}$ \\
\hline $\mathrm{OCF}_{\mathrm{t}} \times \mathrm{PROTECTION}_{\mathrm{t}}$ & - & $\begin{array}{l}-0.059 \\
(-2.710)^{* * *}\end{array}$ & - \\
\hline $\mathrm{OCF}_{\mathrm{t}} \times \mathrm{STRUCTURE}_{\mathrm{t}}$ & - & - & $\begin{array}{l}-0.117 \\
(-2.388)^{* * *}\end{array}$ \\
\hline $\mathrm{OCF}_{\mathrm{t}} \times$ ANTI_TAKEOVER $\mathrm{t}$ & - & - & $\begin{array}{c}-0.035 \\
(-1.399)^{*}\end{array}$ \\
\hline
\end{tabular}


Table 3.3 (Continued)

\begin{tabular}{|c|c|c|c|}
\hline Independent variable & Expected sign & $\begin{array}{l}\text { Coefficient } \\
\text { (t-statistic) }\end{array}$ & $\begin{array}{l}\text { Coefficient } \\
\text { (t-statistic) }\end{array}$ \\
\hline \multicolumn{4}{|l|}{ Control variables } \\
\hline$\triangle$ SALES $_{\mathrm{t}}$ & + & $\begin{array}{l}0.018 \\
(3.009)^{* * *}\end{array}$ & $\begin{array}{l}0.0179 \\
(2.996)^{* * *}\end{array}$ \\
\hline SALESGROWTH $_{\mathrm{t}+1}$ & + & $\begin{array}{c}0.012 \\
(1.268)\end{array}$ & $\begin{array}{c}0.013^{*} \\
(1.317)\end{array}$ \\
\hline $\mathrm{OCF}_{\mathrm{t}} \times \mathrm{SIZE}_{\mathrm{t}}$ & $?$ & $\begin{array}{c}-0.009 \\
(-0.681)\end{array}$ & $\begin{array}{c}-0.011 \\
(-0.835)\end{array}$ \\
\hline Number of observations & & 1,081 & 1,081 \\
\hline F-value & & $42.676^{+++}$ & $41.088^{+++}$ \\
\hline Adjusted $\mathrm{R}^{2}$ & & $47.0 \%$ & $47.1 \%$ \\
\hline
\end{tabular}

The variables are defined as follows:

$\mathrm{ACCR}_{\mathrm{t}} \quad=$ Working capital accruals in year $t$, defined as non-cash working capital minus provisions in year $t$, scaled by end-of-year total assets, minus noncash working capital minus provisions in year $t$-1, scaled by beginning-ofyear total assets;

$\mathrm{OCF}_{\mathrm{t}}$

$=$ Operating cash flow in year $t$, defined as net income in year $t$, scaled by end-of-year total assets, minus $\mathrm{ACCR}_{t}$;

CONCENTRATION $_{\mathrm{t}}=$ Herfindahl concentration index of share ownership in year $t$;

PROTECTION $_{\mathrm{t}}=$ Number of protective measures in place in year $t$, i.e., the sum of STRUCTURE $_{\mathrm{t}}$ and ANTI TAKEOVER ; $_{\mathrm{t}}$

STRUCTURE $_{\mathrm{t}}=$ Indicator variable equal to 1 if a firm is a structure firm in year $t$

ANTI_TAKEOVER $\mathrm{t}_{\mathrm{t}}=$ Number of anti-takeover defense mechanisms in place in year $t$;

$\triangle \mathrm{SALES} \mathrm{S}_{\mathrm{t}}$

$=$ Change in sales in year $t$, defined as sales in year $t$, scaled by end-of-year total assets, minus sales in year $t$-1, scaled by beginning-of-year total assets;

SALESGROWTH $_{\mathrm{t}+1}=$ Percentage change in sales from year $t$ to year $t+1$;

$\mathrm{SIZE}_{\mathrm{t}} \quad=$ Natural logarithm of end-of-year total assets.

Coefficients on interactions between OCF and industry and year dummies are included in the regression but not separately reported. I estimate the regression after removing the top and bottom one percent of the distribution of $\mathrm{ACCR}_{t}$ and $\mathrm{OCF}_{\mathrm{t}}$. Reported t-statistics are based on heteroskedasticity and autocorrelation consistent standard errors (Newey and West 1987).

$* * *, * *$, and $*\left({ }^{++},{ }^{++}\right.$, and $\left.{ }^{+}\right)$denotes statistical significance at the 1,5 , and 10 percent one-tailed (twotailed) alpha level, respectively.

(STRUCTURE) and a discrete measure of the number of takeover defenses in place (ANTI_TAKEOVER). Table 3.3 also presents the results from estimating model (1) after I replace PROTECTION with STRUCTURE and ANTI_TAKEOVER. The results show that both variables, interacted with operating cash flows, are significantly negative $(\mathrm{p}<0.01$ and $\mathrm{p}<0.10$ one-tailed, respectively).

The coefficients on the controls for current $(\triangle S A L E S)$ and future changes in working capital needs (SALESGROWTH) are both in the expected direction, although the coefficient on SALESGROWTH is insignificant. Firm size does not appear to 
influence the accruals-cash flow relation. Overall, the results are consistent with the hypothesis that firms with stakeholder-oriented governance structures smooth earnings to a greater extent than firms with shareholder-oriented governance structures.

\subsubsection{Conservatism test}

Table 3.4 presents the OLS results of equation (2). The first model specification shows that the coefficients on CONCENTRATION and PROTECTION are significantly negative $(\mathrm{p}<0.05$ and $\mathrm{p}<0.10$ one-tailed, respectively), which is consistent with the expectation that a stakeholder-oriented governance model is associated with more conservative financial reporting. Decomposing the PROTECTION measure into STRUCTURE and ANTI_TAKEOVER shows that the effect of PROTECTION on conservatism is driven by the number of takeover defense mechanisms in place. As can be seen from the second model specification in Table 3.4, the coefficient on ANTI_TAKEOVER is significantly negative $(\mathrm{p}<0.05$ one-tailed), whereas the coefficient on STRUCTURE is not significant.

The coefficients on the control variables that capture other possible drivers of conservative reporting are in the expected direction and statistically significant, with the exception of SALESGROWTH. The coefficients on current year's stock return and three lagged returns, which control for temporary differences between book and market value, are all significantly negative. In sum, the results are consistent with the hypothesis that firms with stakeholder-oriented governance structures report more conservatively than firms with shareholder-oriented governance structures.

Table 3.4

OLS regression analysis of the influence of stakeholder orientation on a market-based measure accounting conservatism

\begin{tabular}{lccc}
\hline Independent variable & Expected sign & $\begin{array}{c}\text { Coefficient } \\
\text { (t-statistic) }\end{array}$ & $\begin{array}{c}\text { Coefficient } \\
\text { (t-statistic) }\end{array}$ \\
\hline Intercept & $?$ & 1.762 & 1.734 \\
& & $(8.689)^{+++}$ & $(8.456)^{+++}$ \\
Governance variables $_{\text {CONCENTRATION }_{\mathrm{t}}}$ & - & -0.222 & -0.225 \\
& - & $(-1.845)^{* *}$ & $(-1.868)^{* *}$ \\
PROTECTION $_{\mathrm{t}}$ & - & -0.030 & - \\
STRUCTURE $_{\mathrm{t}}$ & - & $-1.524)^{*}$ & 0.017 \\
& - & - & $(0.399)$ \\
ANTI_TAKEOVER $_{\mathrm{t}}$ & & & -0.048 \\
& & & $(-1.987)^{* *}$
\end{tabular}


Table 3.4 (Continued)

\begin{tabular}{lccc}
\hline Independent variable & Expected sign & $\begin{array}{c}\text { Coefficient } \\
\text { (t-statistic) }\end{array}$ & $\begin{array}{c}\text { Coefficient } \\
\text { (t-statistic) }\end{array}$ \\
\hline $\begin{array}{l}\text { Control variables } \\
\text { SIZE }_{\mathrm{t}}\end{array}$ & $?$ & -0.007 & -0.004 \\
SALESGROWTH $_{\mathrm{t}}$ & - & $-0.568)$ & $(-0.360)$ \\
ROA $_{\mathrm{t}}$ & - & 0.070 & 0.071 \\
LEVERAGE $_{\mathrm{t}}$ & - & $-0.861)$ & $(0.845)$ \\
& -3.451 & -3.427 \\
DIVIDENDS $_{\mathrm{t}}$ & - & $-5.783)^{* * *}$ & $(-5.744)^{* * *}$ \\
STD_ROA $_{\mathrm{t}}$ & - & -0.863 & -0.884 \\
& & $-5.579)^{* * *}$ & $(-5.749)^{* * *}$ \\
Number of observations & -1.700 & -1.718 \\
F-value & & $-2.233)^{* *}$ & $(-2.292)^{* *}$ \\
Adjusted R & -2.638 & -2.564 \\
\hline
\end{tabular}

The variables are defined as follows:

BTM $_{\mathrm{t}} \quad=$ Book to market ratio in year $t$, defined as the ratio of end-of-year book value of equity to end-of-year market value of equity;

CONCENTRATION $_{\mathrm{t}}=$ Herfindahl concentration index of share ownership in year $t$;

PROTECTION $_{\mathrm{t}}=$ Number of protective measures in place in year $t$, i.e., the sum of STRUCTURE $_{\mathrm{t}}$ and ANTI_TAKEOVER ; $_{\mathrm{t}}$

STRUCTURE $_{\mathrm{t}} \quad=$ Indicator variable equal to 1 if a firm is a structure firm in year $t$;

ANTI_TAKEOVER $\mathrm{t}_{\mathrm{t}}=$ Number of anti-takeover defense mechanisms in place in year $t$;

SIZE $_{\mathrm{t}}{ }^{-}=$Natural logarithm of end-of-year total assets;

SALESGROWTH $_{\mathrm{t}} \quad=$ Percentage change in sales from year $t$-1 to year $t$;

$\mathrm{ROA}_{\mathrm{t}}$

LEVERAGE $_{\mathrm{t}}$

DIVIDENDS $_{\mathrm{t}}$

$=$ Return on assets in year $t$, defined as the ratio of net income before extraordinary items in year $t$ to end-of-year total assets;

$=$ The ratio of end-of-year liabilities to end-of-year total assets;

$=$ Dividends declared out of year $t$ net income, scaled by end-of-year total assets;

STD_ROA $\quad=$ The standard deviation of $\mathrm{ROA}_{\mathrm{t}}, \mathrm{ROA}_{\mathrm{t}-1}$, and $\mathrm{ROA}_{\mathrm{t}-2}$ (if available);

$\mathrm{RET}_{\mathrm{t}}^{-} \quad=$ Stock return over the twelve month period ending at year $t$ fiscal year-end.

Coefficients on industry dummies, year dummies, $\mathrm{RET}_{\mathrm{t}}, \mathrm{RET}_{\mathrm{t}-1}, \mathrm{RET}_{\mathrm{t}-2}$, and $\mathrm{RET}_{\mathrm{t}-3}$ are included in the regression but not separately reported. Reported t-statistics are based on heteroskedasticity and autocorrelation consistent standard errors (Newey and West 1987).

$* * *, * *$, and $*\left(^{+++},++\right.$, and $\left.{ }^{+}\right)$denotes statistical significance at the 1,5 , and 10 percent one-tailed (twotailed) alpha level, respectively.

\subsubsection{Meeting or beating analyst earnings forecasts test}

Table 3.5 reports the results of estimating equation (3) by logistic regression. Because I am interested in cases where management actively attempts to beat (or meet) analyst expectations by a small margin, I examine a subset of my observations for which the 
forecast error is just above, equal to, or just below 0 . Specifically, I limit my sample to cases where the absolute forecast error (defined as the median analyst earnings per share forecast minus reported earnings per share) before the earnings announcement date is equal to or below 0.1 percent of the share price at the announcement date. In the first model specification in Table 3.5, the coefficients on CONCENTRATION and PROTECTION are significantly negative ( $\mathrm{p}<0.05$ and $\mathrm{p}<0.01$ one-tailed, respectively), which confirms my hypothesis that firms with a stakeholder-oriented governance structure are less likely to meet or beat analyst forecasts. In the second specification, I include STRUCTURE and ANTI_TAKEOVER separately. Again, the coefficients on my proxies for stakeholder orientation (i.e., CONCENTRATION, STRUCTURE, and ANTI_TAKEOVER) are all significantly negative $(\mathrm{p}<0.05, \mathrm{p}<0.01$, and $\mathrm{p}<0.05$ onetailed, respectively).The coefficients on SALESGROWTH and \%OLD_FORECASTS are significant and in the expected direction. $\triangle E P S$ is only significant and in the expected direction in the second model specification. SIZE and EPS are not significantly related to the likelihood of meeting or beating analyst forecasts.

To examine the sensitivity of my results to the definition of 'small' absolute forecasts errors I estimate the second specification of my model again, but expand the interval of absolute forecast errors to include errors of 0.5 percent or less. Untabulated results show that the significance of the coefficients on STRUCTURE ( $<0.10$ onetailed) and ANTI_TAKEOVER ( $\mathrm{p}=0.16$ one-tailed) decrease. Expanding the interval to include errors of 1 percent or less lowers the significance of my proxies even further. Specifically, only CONCENTRATION and STRUCTURE remain significant $(\mathrm{p}<0.10$

Table 3.5

Logistic regression analysis of the influence of stakeholder orientation on meeting or beating analyst earnings forecasts

\begin{tabular}{lccc}
\hline Independent variable & Expected sign & $\begin{array}{c}\text { Coefficient } \\
\left(\text { Wald } \chi^{2}\right)\end{array}$ & $\begin{array}{c}\text { Coefficient } \\
\left(\text { Wald } \chi^{2}\right)\end{array}$ \\
\hline Intercept & $?$ & 2.576 & 3.022 \\
& - & $(2.942)^{+}$ & $(3.762)^{+}$ \\
Governance variables & & -1.777 & -1.884 \\
CONCENTRATION $_{\mathrm{t}}$ & - & $(2.972)^{* *}$ & $(3.233)^{* *}$ \\
PROTECTION $_{\mathrm{t}}$ & - & -0.465 & - \\
STRUCTURE $_{\mathrm{t}}$ & - & $(8.250)^{* * *}$ & -0.895 \\
& - & - & $(6.317)^{* * *}$ \\
ANTI_TAKEOVER & & -0.356 & $(3.886)^{* *}$ \\
& & & (Continued on next page) $^{*}$
\end{tabular}


one-tailed) at conventional levels. This decline in statistical significance of my proxies as a result of broadening the interval is not unexpected, because a broad interval is more likely to measure forecast optimism versus pessimism instead of beating expectations. As such, I interpret the decline in significance as confirmation that the dependent variable in my original specification measures firms' beating behavior, as opposed to analysts' forecast bias. ${ }^{7}$

Table 3.5 (Continued)

\begin{tabular}{|c|c|c|c|}
\hline Independent variable & Expected sign & $\begin{array}{l}\text { Coefficient } \\
\left(\text { Wald } \chi^{2}\right)\end{array}$ & $\begin{array}{l}\text { Coefficient } \\
\text { (Wald } \chi^{2} \text { ) }\end{array}$ \\
\hline \multicolumn{4}{|l|}{ Control variables } \\
\hline $\mathrm{SIZE}_{\mathrm{t}}$ & + & $\begin{array}{l}-0.082 \\
(0.787)\end{array}$ & $\begin{array}{l}-0.105 \\
(1.222)\end{array}$ \\
\hline $\mathrm{EPS}_{\mathrm{t}}$ & + & $\begin{array}{l}-0.839 \\
(0.090)\end{array}$ & $\begin{array}{l}-0.490 \\
(0.031)\end{array}$ \\
\hline$\Delta \mathrm{EPS}_{\mathrm{t}}$ & + & $\begin{array}{c}3.360 \\
(1.387)\end{array}$ & $\begin{array}{c}3.666 \\
(1.645)^{*}\end{array}$ \\
\hline SALESGROWTH $_{\mathrm{t}}$ & + & $\begin{array}{c}1.372 \\
(2.416)^{*}\end{array}$ & $\begin{array}{l}1.499 \\
(2.814)^{* * *}\end{array}$ \\
\hline$\% O L D \_F O R E C A S T_{t}$ & + & $\begin{array}{c}1.723 \\
(2.065)^{*}\end{array}$ & $\begin{array}{c}1.739 \\
(2.068)^{*}\end{array}$ \\
\hline $\begin{array}{l}\text { Number of observations } \\
\mathrm{n} \mid \mathrm{BEAT}_{\mathrm{t}}=1 \\
\mathrm{n} \mid \mathrm{BEAT}_{\mathrm{t}}=0\end{array}$ & & $\begin{array}{c}240 \\
159 \\
81\end{array}$ & $\begin{array}{c}240 \\
159 \\
81\end{array}$ \\
\hline Likelihood ratio & & $15.386^{++}$ & $17.327^{++}$ \\
\hline Pseudo $\mathrm{R}^{2}$ & & $5.0 \%$ & $5.6 \%$ \\
\hline
\end{tabular}

The variables are defined as follows:

BEAT $_{\mathrm{t}} \quad=$ Indicator variable equal to 1 if a firm's EPS meets or exceeds the median analyst earnings forecast outstanding at the firm's year $t$ earnings announcement date;

CONCENTRATION $_{\mathrm{t}}=$ Herfindahl concentration index of share ownership in year $t$;

PROTECTION $_{\mathrm{t}}=$ Number of protective measures in place in year $t$, i.e., the sum of STRUCTURE $_{\mathrm{t}}$ and ANTI_TAKEOVER

STRUCTURE $_{\mathrm{t}} \quad=$ Indicator variable equal to 1 if a firm is a structure firm in year $t$;

ANTI_TAKEOVER $\mathrm{t}_{\mathrm{t}}=$ Number of anti-takeover defense mechanisms in place in year $t$;

$\mathrm{SIZE}_{\mathrm{t}}{ }^{-} \quad=$ Natural logarithm of end-of-year total assets;

$\mathrm{EPS}_{\mathrm{t}} \quad=$ Earnings per share in year $t$, scaled by the end-of-year share price;

$\Delta \mathrm{EPS}_{\mathrm{t}} \quad=$ The change in earnings per share from year $t-1$ to year $t$, scaled by the endof-year share price;

SALESGROWTH $_{\mathrm{t}}=$ The percentage change in sales from year $t-1$ to year $t$;

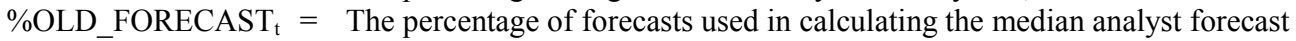
that has been outstanding for more than ninety days at the year $t$ earnings announcement date.

$* * *, * *$, and $*\left(^{+++},++\right.$, and $\left.{ }^{+}\right)$denotes statistical significance at the 1,5 , and 10 percent one-tailed (twotailed) alpha level, respectively. 


\subsubsection{Sensitivity analyses}

In order to test the robustness of my results, I perform the following sensitivity tests:

1. Board monitoring: In one-tier board structures, the board of directors is considered to be the most important internal control mechanism (Fama 1980; Fama and Jensen 1983). In the Dutch setting, the monitoring role is performed by the Supervisory Board. To examine the impact of the effectiveness of Supervisory Boards on financial reporting, I add measures for board effectiveness to equations (1), (2), and (3). I control for board size because large boards are considered to be less effective than small boards. As boards become larger, coalition costs increase and freeriding by board members increases (Jensen 1993; Yermack 1996). In addition, Beasley (1996) and Vafeas (2000) find that financial reporting quality decreases with board size. Furthermore, I include the average number of additional directorships held by Supervisory Board members. This variable can be considered as a signal of a director's reputation (Kaplan and Reishus 1990) or, alternatively as an indicator for the extent to which a director is 'busy' and can devote less time to each directorship (Core et al. 1999). Beasley (1996) finds support for the latter argument by documenting a positive relation between the number of directorships and the likelihood of financial statement fraud. Finally, I control for the average age of board members. Older board members can be considered to be either less effective monitors (Core et al. 1999) or less susceptible to group pressure and therefore more effective monitors (Beasley 1996). I add three variables, measuring the size of the Supervisory Board, the average number of additional directorships, and the average age of supervisory directors to regression equations (1), (2), and (3). In equation (1) the variables enter as interactions with $O C F$. The results (unreported) show that none of these board characteristics influence smoothing behavior or conservatism, while the results reported earlier remain largely unchanged. That is, coefficients on the main variables of interest, CONCENTRATION and PROTECTION remain significantly negative, except for the earnings smoothing test that includes STRUCTURE and ANTI_TAKEOVER separately in equation (1), where the coefficient on ANTI_TAKEOVER is negative but no longer statistically significant ( $\mathrm{p}=0.11$, one-tailed). When I include the board monitoring variables in equation (3), only the average age of board members is significantly negatively related to the likelihood of meeting or beating analyst forecast. The signs and significance of the main variables of interest remain unchanged.

2. U.S. exchange listing: By listing on a U.S. stock exchange, foreign firms subject themselves to SEC regulation and enforcement. U.S. accounting standards are considered to be targeted at the interests of minority shareholders and the 
enforcement environment in the U.S. is considered to be very strict. To test whether my results are sensitive to including U.S. exchange listing, I add an indicator variable that equals 1 if a firm is listed on a U.S. stock exchange (12.9 percent of my observations) and 0 otherwise to regression equations (1), (2), and (3). In regression equation (1) the variable is included as an interaction term with $O C F$. The results (unreported) show that U.S. listing is not significantly related to either smoothing behavior, conservatism, or the likelihood of meeting or beating analyst expectations. My main results are robust to the inclusion of this control variable and remain qualitatively similar.

3. Alternative definitions of accruals: As explained earlier, I define working capital accruals as the change in working capital, minus the change in provisions. As a first test, I leave the change in provisions out of my accruals measure. The results from estimating equation (1) are robust to this alternative definition. As a second robustness check, I follow prior research on earnings management and use total accruals as my accruals measure, defined as the change in non-cash working capital minus depreciation expense. I then use the Modified Jones model to decompose total accruals into a discretionary and a non-discretionary part, using $\triangle S A L E S$, the end-of-year level of property, plant, and equipment, and next year's SALESGROWTH (following Dechow et al. 2003) as drivers of non-discretionary accruals. In the final step, I substitute my measure of accruals in equation (1) with the estimated discretionary component of total accruals. The results (unreported) show that my proxies for the stakeholder orientation of a firm remain significantly negatively associated with the correlation between accruals and cash flows.

4. Goodwill write-offs: During the sample period, Dutch firms frequently wrote off purchased goodwill against equity immediately on acquisition, instead of amortizing it through the income statement. Because this dirty surplus flow reduces book value relative to market value (the dependent variable in equation (2)), but is not a determinant of unconditional earnings conservatism, I control for goodwill write-offs in the current year and the two previous years (scaled by market value at the end of the corresponding fiscal year) in equation (2). The coefficients on these control variables are significantly negative as predicted, but the coefficients on my variables of interest (CONCENTRATION, PROTECTION, ANTI_TAKEOVER, and $S T R U C T U R E)$ remain significantly negative.

\subsection{Discussion and concluding remarks}

In this study, I examine the influence of Dutch firms' corporate governance structures on properties of their accounting. I argue that firms that are shielded from the influence of minority shareholders and from the threat of takeover, through high 
ownership concentration, the use of takeover defense mechanisms, or being subject to the structure regime, adopt a stakeholder-oriented financial reporting system. I hypothesize that in stakeholder-orientated firms financial reporting plays a substantially different role than in shareholder-oriented firms, for which providing timely information to capital market participants is the key objective of financial reporting. Stakeholder-oriented financial reporting is mainly driven by payout determination. That is, maintaining a strong financial position and avoiding excessive payouts to any of the firm's stakeholders is an important objective of stakeholderoriented financial reporting. I predict and find that firms with a stakeholder orientation more actively smooth earnings, report more conservatively, and are less inclined to exhibit myopic reporting behavior, as measured by meeting or beating analyst earnings forecasts, than firms with a shareholder orientation.

The study in this chapter contributes to the literature in three interrelated ways. First, I examine financial reporting choices in a setting that has some unique characteristics. The Netherlands has shareholder-oriented accounting regulation, but provides firms sufficient opportunities to adopt a stakeholder orientation. As a result, financial reporting objectives of individual firms do not necessarily coincide with the objectives of the regulator, which allows us to examine how these deviations affect financial reporting. Second, in contrast with studies examining the effect of governance orientation on financial reporting at the country level (e.g., Ball et al. 2000; Ball et al. 2003; Leuz et al. 2003), I examine the effect of governance orientation on financial reporting at the firm level. By keeping regulation and other institutional influences constant, I am able to provide direct evidence that firm-specific financial reporting incentives are an important determinant of financial reporting properties. Finally, my results indicate that Dutch stakeholder-oriented firms are less likely to report in accordance with the shareholder-oriented objectives of the accounting regulator, which suggests that firm-level reporting incentives dominate regulatory incentives if enforcement is relatively weak.

An important implication of my results is that an attempt to move in the direction of shareholder-oriented financial reporting solely through reforms in accounting regulation is unlikely to be successful. For example, it is questionable whether the implementation of IAS in the European Union will lead to more shareholder-oriented reporting, because firm-level reporting incentives, which are a function of a firm's relationships with shareholders and other stakeholders, will not change simultaneously. In addition, other aspects of the institutional environment, such as enforcement, are still relatively weak and are only beginning to be reformed in most EU Members States. 


\section{Notes}

1 Because shareholders of Dutch firms have not been allowed to vote by proxy, the large absenteeism of shareholders at the Annual Meetings implies that minority shareholders can potentially have a large influence on firm decisions.

2 The description of the authorities of the Supervisory Boards of firms subject to the structure regime in this chapter applies to the situation during the period studied. Recently, Dutch corporate governance has been reformed. In general the changes strengthen the position of the shareholders at the expense of the Supervisory Board. See chapter 5 for a more detailed description of the changes.

3 The takeover defense mechanisms I study (priority shares, voting caps, depository receipts, and preferred defense shares) are the most widely adopted mechanisms by Dutch firms (Kabir et al. 1997). Mechanisms such as poison pills or golden parachutes are uncommon in the Netherlands.

4 Hribar and Collins (2002) indicate that an artificial negative correlation between accruals and cash flows could be created if (i) cash flows are defined as earnings minus accruals and (ii) if mergers and acquisitions, discontinued operations, or exchange rate changes affect balance sheet items. A potential solution to this problem is to use accruals and cash flows from the firms' cash flow statements. However, because I do not have such data available, I use an alternative solution by scaling working capital in year $t(t-1)$ by total assets from the same year $t(t-1)$ and calculating working-capital accruals as changes in scaled working capital. This contrasts with the commonly used approach of defining accruals as changes in working capital in year $t$, scaled by total assets from year $t-1$. Because working capital and total assets from one particular year are similarly affected by events such as mergers and acquisitions, scaling working capital by total assets from the same year should reduce the distorting effect of the problems described by Hribar and Collins.

5 Because I exclude financial firms, my sample does not include firms from the 'Financial institutions' and 'Insurance and real estate' industries. The industry groupings 'Pharmaceuticals', 'Utilities', and 'Other' are not represented in my sample. Due to the small size of the 'Extractive industries' group, I combined it with the 'Chemicals' industry.

6 The results of my logistic regression analysis remain qualitatively unchanged if I replace EPS and $\triangle E P S$ with a dummy variable equal to one if a firm reports a loss and a dummy variable equal to one if a firm reports an earnings decrease, respectively.

7 Additional support for this argument is provided by the fact that broadening the interval increases the sample size and thus statistical power, which, all else equal, should lead to increased significance instead of decreased significance. 


\section{Chapter 4}

\section{The Effect of Institutional Factors on Accounting Properties for Firms with Different Ownership Structures}

\subsection{Introduction}

Firms' reporting objectives are influenced by two main classes of factors: firm-specific influences, such as their ownership structures, corporate governance, and method of financing, and the institutional environment of their country of domicile. A substantial stream of accounting research has documented international differences in financial reporting (e.g., Alford et al. 1993; Joos and Lang 1994) and has studied determinants of such differences (e.g., Ali and Hwang 2000, Ball et al. 2000, Leuz et al. 2003). Other accounting research has studied firm-specific determinants of financial reporting choices, such as exchange listings (Ball and Shivakumar 2005), ownership structures (Fan and Wong 2002), managerial ownership (Warfield et al. 1995), and financing structures (Ahmed et al. 2002). Chapter 3 of this dissertation, where I examine the effect of the reporting incentives generated by firms' governance structures on accounting properties, also fits into this line of research.

Ball et al. (2003) find that IFRS introduction in East Asian countries does not seem to result in more shareholder-oriented reporting. They attribute this finding to the influence that other institutional factors, besides accounting regulation, and firmspecific reporting incentives have on firms' reporting objectives and consequently on their accounting choices. With the exception of Burgstahler et al. (2006) and Peek et al. (2007), most prior studies do not examine whether the influence of institutions on firms' financial reporting choices differs depending on firm characteristics. Such knowledge is relevant for firms' shareholders and other stakeholder in interpreting financial statement information, but also for regulators trying to assess the impact of (changes to) the institutional environment on firms with different reporting incentives.

The study presented in this chapter investigates the influence of a country's institutional orientation on firms' financial reporting objectives conditional on the reporting incentives generated by firms' ownership structures. Financial reporting can have different objectives. As in chapter 3, I distinguish between stakeholder-oriented objectives, where payout determination is the main objective, and shareholder-oriented objectives, where the main function of financial reporting is timely information 
provision to shareholders. Because firms' reporting objectives are not directly observable, I examine two properties of accounting information - unconditional conservatism and earnings smoothing - that should be a reflection of a firm's reporting orientation. Firms with stakeholder-oriented reporting objectives are expected to report more conservatively and smooth earnings more actively than firms with shareholderoriented reporting objectives. I classify countries' institutional environments along the same lines, i.e. stakeholder- versus shareholder-oriented. A factor score of four institutional factors is created to capture differences in the institutional orientation of countries. I hypothesize that closely held firms' financial reporting choices are to a greater extent influenced by the institutional environment of their country of domicile than widely held firms' reporting choices. Reporting incentives of widely held firms are mainly driven by capital market demand for shareholder-oriented reporting. Because shareholders in these firms are at arm's length and rely on public financial reporting for information provision, they will demand informative financial reporting. In stakeholder-oriented economies, widely held firms' shareholder-oriented reporting incentives are not congruent with the country's institutional orientation. I nevertheless expect that these firms will report shareholder-oriented, because (i) failure to reduce information asymmetries can lead to a higher cost of equity capital (Botosan 1997) and (ii) in stakeholder-oriented countries, firms can usually make certain accounting choices within local GAAP or provide additional voluntary disclosures to make reporting more informative.

Large shareholders in closely held firms typically have access to private information and financial reporting can therefore serve different goals, like determination of payouts to various stakeholders. I hypothesize that the effect of institutions on closely held firms' reporting is larger than on widely held firms' reporting, because closely held firms domiciled in countries with shareholder-oriented institutions face relatively high costs of non-compliance. Dispersed shareholders in closely held firms, who do not have access to private information and thus demand informative financial reporting, are better protected in shareholder-oriented institutional environments. In addition to having higher minority investor rights protection, accounting regulation in shareholder-oriented countries typically has a higher degree of determination and is better enforced than in stakeholder-oriented economies, which also increases the costs of non-compliance for closely held firms.

I use data from Western European firms to provide evidence on the role of the institutional environment on financial reporting across firms with different levels of ownership concentration. In accordance with my hypothesis that institutions have a larger influence on closely held than on widely held firms' reporting choices, I find that the level of (unconditional) conservatism is not dependent on a country's institutional orientation for the most widely held group of firms, but that institutions 
increasingly influence conservatism the more closely held a firm becomes. Contrary to expectations, I find that the influence of institutions on firms' earnings smoothing behavior does not depend on ownership concentration, but that widely held and closely held firms are equally affected by a country's institutional orientation.

This study complements the study in chapter 3 - where I study the influence on firm-specific reporting incentives on accounting choices while holding the institutional environment constant - by studying the effect of institutions on reporting behavior, conditional on firms' ownership structures. Most international accounting studies implicitly assume that institutions influence all firms' accounting properties equally. Earlier studies, e.g., Ali and Hwang (2000), Ball et al. (2000), Leuz et al. (2003), study the effect of international differences in institutional environments on properties of firms' financial reporting without explicitly considering the moderating influence of firm-specific reporting incentives. Firms' reporting incentives are partly influenced by the institutional orientation of a country (La Porta et al. 1999). Certain ownership structures or methods of corporate governance are related to institutional factors such as investor protection. However, these firm characteristics are only partly explained by institutional influences. For example, Becht and Röell (1999) document substantial variation in firms' level of ownership concentration within countries. Knowing how different types of firms respond to institutional reporting influences could be beneficial to various market participants. It helps various stakeholders in determining if a firm's financial reporting can be easily compared internationally or is more likely reflective of the institutional environment of its country of domicile. Regulators could assess how the impact of (changes to) accounting standards or enforcement mechanisms differs across firms.

Few prior studies have investigated the simultaneous impact of firm-specific incentives and institutional factors on financial reporting. Burgstahler et al. (2006) study the influence of an institutional variable, the quality of legal enforcement, and a firm's listing status, private versus public, on earnings management behavior and find that both influence firms' earnings management behavior. In a supplemental analysis, they examine whether the influence of various institutional characteristics differs for private and public firms and document that the effect of some institutional variables differs depending on listing status. LaFond (2005) studies whether the effect of firms' ownership structures dominates the effect of institutions on financial reporting and finds that minority investor rights protection significantly influences (conditional) conservatism but that the effect of investor rights becomes less influential by controlling for the effect of firms' ownership structures. Peek et al. (2007) study the differential effect of institutional variables, creditor protection and investor protection, on private versus public firms' level of (conditional) conservatism. The study in this chapter extends these studies in several ways. First, instead of relying on listing status 
to measure firms' reporting incentives, I use a measure of ownership concentration, following LaFond (2005). This allows me to measure firm-specific reporting incentives as a continuous variable. ${ }^{1}$ Second, I focus on listed firms only, which makes it possible to conduct market-based tests of conservatism. Third, I capture institutional differences using a factor score of four variables, which provides a more refined picture of a country's institutional environment compared to including one institutional variable at a time or including institutional variables separately. Fourth, this study adds to LaFond (2005) by explicitly examining the moderating effect of ownership structure on the influence of institutions. Also, I extend Burgstahler et al. (2006) and Peek et al. (2007), who focus on earnings management and (conditional) conservatism, respectively, by studying different properties of accounting.

The remainder of this chapter is organized as follows. First, I develop my hypotheses. Next, I describe the data and sample selection. I will continue with the results and conclude with a discussion and concluding remarks.

\subsection{Theory and hypotheses}

\subsubsection{Objectives of financial reporting}

Financial reporting does not have the same primary objective for all firms. Following prior research, I make a distinction between stakeholder- and shareholder-oriented financial reporting. ${ }^{2}$ Shareholder-oriented accounting tends to be focused at providing timely and reliable information about the firm to equity investors in order to enable them to evaluate performance to base, e.g., investment, management compensation, or CEO dismissal decisions on. Stakeholder-oriented financial reporting takes a broader perspective and tries to serve the interests of all stakeholders in the firm. To protect stakeholders' interests, its main objective is avoiding excessive payouts to any stakeholder (e.g., bonus payments to management or dividend payments to equity investors) in order to ensure the financial health and stability of the firm.

The difference in objectives of financial reporting translates into different properties of accounting numbers in these two benchmark systems. When a firm's reporting objectives are stakeholder-oriented, I expect that accounting discretion is used for payout determination, i.e., to avoid excessive payouts. Specifically, I expect that firms avoid large fluctuations in net income, because these fluctuations in net income increase the chance that firms make unwarranted payouts based on temporarily high earnings numbers. I also expect that firms with stakeholder-oriented reporting objectives make (unconditionally) conservative accounting estimates, i.e., defer recognition of potential gains and accelerate recognition of potential losses and consequently understate assets and overstate liabilities. Besides providing a conservative estimate of net income, which serves as the basis for the determination of 
dividends, this also ensures that net assets, as reflected on the balance sheet, are valued conservatively, i.e. assets are never overvalued and liabilities are never undervalued. As discussed in chapter 3, these accounting choices (using discretion to smooth earnings and make conservative accounting estimates) can interfere with providing informative performance measures to shareholders. ${ }^{3}$ I therefore expect firms with shareholder-oriented reporting objectives to engage in less earnings smoothing and less (unconditionally) conservative reporting than firms with stakeholder-oriented reporting objectives.

\subsubsection{Countries' institutional orientation and firms' reporting objectives}

A firm's financial reporting objectives are partly influenced by the institutional environment that a firm faces. Alford et al. (1993) and Joos and Lang (1994) find that financial reporting properties differ internationally. Later studies (Ali and Hwang 2000, Ball et al. 2000, Hung 2001, Leuz et al. 2003) attribute these international differences in accounting properties to differences in institutional structures across countries. These studies have identified two main groups of countries with different institutional influences on financial reporting, which are labeled market- versus bankoriented (Ali and Hwang 2000), common- versus code-law (Ball et al. 2000), or outsider versus insider systems (Leuz et al. 2003). I consistently use the terms shareholder- and stakeholder-oriented throughout this study to describe differences in the objective of financial reporting, both at the country and at the firm level. ${ }^{4}$

Countries differ in the role that is attributed to financial reporting. This is commonly traced back to differences in countries' legal systems. The influence of governments on business and accounting is different under both systems. In common law countries, governments set and enforce private property rights, which results in strong protection of minority investor rights and accounting standard setting by private sector bodies that tend to promote the interests of (minority) shareholders. This stands in contrast to countries with code law systems, where legal protection of investors is weak, but the political influence of governments and other corporate stakeholders on businesses is strong. This political influence on business extends to financial reporting. Accounting standards are typically set by a public sector body and financial reporting's main goal is the determination of payouts to different stakeholder groups. The importance of payout determination in stakeholder-oriented economies often leads to a strong link between tax and financial reporting. Leuz and Wüstemann (2004) indicate that regulators in stakeholder-oriented countries view earnings that serve as a basis for dividend payouts as a good basis for tax determination as well and consequently also as a basis for payouts to all stakeholders. The principle of payout 
determination in stakeholder-oriented countries leads to income numbers that try to capture the funds available for distribution to various stakeholders.

In shareholder-oriented economies the focus is on information provision to shareholders. This difference in the main objective of financial reporting also translates into differences in accounting rules. Because in shareholder-oriented economies financial reporting is targeted at providing investors with a measure of (economic) performance, regulators in these countries will promote accrual accounting. For example, immediate write-off of purchased goodwill (which is close to cash-based accounting) is more likely to be required by regulators in stakeholderoriented countries to ensure that assets are never overstated. In countries with shareholder-oriented institutions, goodwill is more likely to be capitalized and impaired when necessary, reflecting an accounting loss only when an actual economic loss occurs.

\subsubsection{Reporting objectives of widely held firms across institutional environments}

Firms with widely held ownership structures face capital market demand for informative financial reporting. The dispersed shareholders in these firms typically do not have the means or incentives to obtain information through private channels (Shleifer and Vishny 1986). The arm's length relation between shareholders and managers results in greater reliance on (implicit or explicit) contracting (Ball et al. 2000). Greater use of contracting as opposed to direct monitoring is likely to translate into a greater demand for informative public financial reporting. Furthermore, investments of dispersed shareholders are relatively liquid and therefore they will demand valuation-relevant information. Failure to reduce information asymmetries through informative financial reporting could thus result in an increased cost of capital (Botosan 1997).

The capital market demand for shareholder-oriented financial reporting is not expected to differ across institutional environments. If the stakeholder-oriented institutional environment in some countries would prohibit firms from reporting shareholder-oriented, it could be expected that widely held firms in these countries would report less informatively than their counterparts in shareholder-oriented institutional environments. However, the institutional environment in stakeholderoriented economies is characterized by accounting rules with a relatively low degree of determination (d'Arcy 2000) and relatively weak enforcement (Leuz et al. 2003). A low degree of determination means that firms have a large choice of accounting methods in drawing up their financial statements, which suggests that widely held firms in countries with stakeholder-oriented institutions are able to report shareholderoriented by choosing certain options in accounting rules. It seems likely that 
institutions in stakeholder-oriented countries give firms a certain degree of flexibility to allow them to adapt to the reporting demands of their main stakeholders. In widely held firms, minority shareholders are one of the most important stakeholder groups and financial reporting will be heavily influenced by their demands. Furthermore, these firms can provide additional disclosures that make their financial reporting more informative to shareholders. In the extreme, firms can choose to report according to IAS/IFRS to overcome the stakeholder-oriented financial reporting tradition of their country of domicile. For example German firms such as Adidas, Bayer, and Südzucker have chosen to adopt IAS/IFRS long before the European Commission's mandated adoption date. The analysis in chapter 2 suggests that one of the reasons for firms to switch to non-local GAAP is the low quality of the accounting standards of their country of domicile. Weak enforcement implies that the costs for widely held firms of not complying with the institutional reporting norm in stakeholder-oriented countries are relatively low and likely are outweighed by the benefits of meeting shareholders' demand for informative reporting.

\subsubsection{Reporting objectives of closely held firms across institutional environments}

In closely held firms, most financing is provided by large shareholders that are typically insiders to the firm and have access to private information through direct contact with management. For example, many large shareholders are represented on firms' (supervisory) boards. The need for financial reporting as a mechanism to resolve information asymmetries between shareholders and managers is therefore less than in widely held firms. Financial reporting can thus serve different purposes. The illiquid nature of large shareholders' investments causes them to take a long-term interest in the firm, which means that large shareholders, like many other stakeholder groups, become interested in the survival of the firm. Financial reporting will reflect this stakeholder orientation and will therefore be used in determination of payouts to stakeholders and to ensure the financial stability of the firm.

In stakeholder-oriented countries, the institutional environment is largely targeted at payout determination and closely held firms' incentives are therefore congruent with the country's orientation. However, institutions in shareholder-oriented environments require firms to report shareholder-oriented and view financial reporting as a mechanism to reduce information asymmetries between firms and minority shareholders, irrespective of the ownership structure of the firm. Minority shareholders of closely held firms will demand informative financial reporting irrespective of the country's institutional orientation. However, in shareholder-oriented countries minority investor rights tend to be better protected than in stakeholder-oriented countries (Leuz et al. 2003). Therefore, minority investors are likely to be more 
successful in demanding informative financial reporting in shareholder- than in stakeholder-oriented countries. Furthermore, in some shareholder-oriented countries, accounting regulation has a relatively high degree of determination (d'Arcy 2000), which suggests that within-country variation in firms' reporting practices is lower, because all firms have to apply the same accounting rules that leave relatively little discretion. In summary, closely held firms in countries with institutions that promote shareholder-oriented reporting are likely to report more shareholder-oriented than their counterparts in stakeholder-oriented countries, because I expect the cost of noncompliance with the country's reporting norms to be relatively high in shareholderoriented countries.

\subsubsection{The effect of the institutional environment conditional on ownership structure}

The above discussion implies that the effect of the institutional environment on firms' financial reporting choices differs across firms. The strong capital market pressures to reduce information asymmetries that widely held firms face are expected to result in shareholder-oriented reporting choices, irrespective of the institutional orientation of a firm's country of domicile. The costs of reporting shareholder-oriented for widely held firms in stakeholder-oriented countries are unlikely to be high because these firms can report shareholder-oriented by using the flexibility that stakeholder-oriented accounting rules typically offer or by providing additional disclosures. Consequently, widely held firms' reporting behavior is expected to be relatively homogeneous across countries.

The difference in closely held firms' reporting behavior across various institutional environments is expected be much more diverse. Closely held firms in shareholder-oriented countries face higher costs of not complying with the country's reporting norms than widely held firms in stakeholder-oriented countries, whose reporting incentives are also inconsistent with the country's institutional orientation. The relatively higher degree of determination (d'Arcy 2000) and higher levels of minority investor rights protection cause closely held firms in shareholder-oriented institutional environments to report less stakeholder-oriented than their counterparts in stakeholder-oriented environments. In summary, the influence of the institutional environment on firms' financial reporting decisions is hypothesized to be greater for closely held firms than for widely held firms.

Hypothesis: The influence of a country's institutional orientation on the properties of firms' financial reporting is positively related to firms' concentration of share ownership. 


\subsection{Methodology}

\subsubsection{Data and sample selection}

I use data about European firms from 1991 to 2003 in the analyses. The sample is restricted to the 13 European countries that Faccio and Lang (2002) provide ownership data $^{5}$ for (Austria, Belgium, Finland, France, Germany, Ireland, Italy, Norway, Portugal, Spain, Sweden, Switzerland, and the United Kingdom) and The Netherlands. For The Netherlands, I use the ownership data that is also used in chapter 3, i.e. from the WMZ (Disclosure of Major Holdings in Listed Companies Act) register. ${ }^{6}$ Financial statement data comes from the Worldscope database and stock market data is from Datastream. The final sample consists of all firm-year observations for which ownership data is available and sufficient information is available on both Worldscope and Datastream to compute the variables used in the analyses below.

To capture the differences in institutional orientation across countries, I construct a factor score (cf. Ali and Hwang 2000) of various institutional features that are expected to reflect the difference in the orientation of financial reporting, i.e. stakeholder- versus shareholder-oriented. One advantage of this approach is that it avoids classifying European countries only along the line of legal origin (cf. Ball et al. 2000), which would contrast England (common law) with the rest of the sample countries (code law). Another advantage is that I do not rely on just one measure to classify countries (e.g. Leuz et al. 2003 use the quality of legal enforcement to classify countries), but capture the institutional variation more accurately. I use four institutional features to represent the orientation of a country. I measure the political influence on accounting by the protection of minority investors' rights and by an indicator variable that captures governmental influence on accounting standard setting. The protection of minority investors' rights is measured by the anti-director rights index from La Porta et al. (1998) and includes, for example, whether shareholders are allowed to mail their proxy vote and whether cumulative voting is allowed. The indicator variable takes the value one if a country has a private sector standard setting body and zero if it has a public standard setting body. Weak protection of investor rights and a private sector standard setter indicate low political influence on financial reporting. I therefore expect that these two variables are positively related to the shareholder orientation of a country's institutions.

The other two variables I use to capture a country's institutional orientation, measure the objective of accounting regulation. Financial reporting regulation that has payout determination as an important objective (i.e., a stakeholder-oriented reporting objective), likely uses the same rules for tax and financial reporting and is less likely to be accrual based. I use an indicator variable that equals one if tax and financial reporting are closely aligned. I expect this variable to be negatively related to the 
shareholder orientation of a country's accounting regulation. The extent to which a country's standard setter promotes the use of accrual accounting is measured by the accrual index constructed by Hung (2001). This index captures, for example, whether finance leases, $R \& D$, and intangibles can be capitalized and whether the percentage of completion method is allowed or required. I expect this variable to be positively related to a country's shareholder-orientation.

As shown in Table 4.1, factor analysis on these four variables at the country level results in one factor with an eigen value greater than 1 (2.681). As expected, the investor protection index (factor loading: 0.772), the existence of a private sector standard setting body (0.771), and the accrual index (0.853) load positively and alignment between tax and financial reporting (-0.874) loads negatively on this factor. Therefore, I classify countries with a high factor score as more shareholder-oriented

Table 4.1

Institutional orientation of sample countries

\begin{tabular}{|c|c|c|c|c|c|c|}
\hline \multirow{2}{*}{ Country } & \multirow{2}{*}{$\begin{array}{l}\text { Investor } \\
\text { protection }\end{array}$} & \multirow{2}{*}{$\begin{array}{l}\text { Source of } \\
\text { accounting } \\
\text { rules }\end{array}$} & \multirow{2}{*}{$\begin{array}{c}\text { Financial/tax } \\
\text { accounting } \\
\text { alignment }\end{array}$} & \multirow{2}{*}{$\begin{array}{l}\text { Accrual } \\
\text { index }\end{array}$} & \multicolumn{2}{|c|}{$\begin{array}{l}\text { Institutional } \\
\text { orientation }\end{array}$} \\
\hline & & & & & Factor score & Rank \\
\hline Austria & 2 & 0 & 1 & 0.41 & -0.891 & 11 \\
\hline Belgium & 0 & 0 & 1 & 0.68 & -0.796 & 10 \\
\hline Finland & 3 & 0 & 1 & 0.55 & -0.421 & 9 \\
\hline France & 3 & 0 & 1 & 0.64 & -0.252 & 7 \\
\hline Germany & 1 & 0 & 1 & 0.41 & -1.098 & 14 \\
\hline Ireland & 4 & 1 & 0 & 0.82 & 1.602 & 2 \\
\hline Italy & 1 & 0 & 1 & 0.45 & -1.022 & 12 \\
\hline The Netherlands & 2 & 1 & 0 & 0.73 & 1.020 & 3 \\
\hline Norway & 4 & 0 & 1 & 0.82 & 0.294 & 5 \\
\hline Portugal & 3 & 0 & 1 & 0.59 & -0.346 & 8 \\
\hline Spain & 4 & 0 & 0 & 0.77 & 0.895 & 4 \\
\hline Sweden & 3 & 1 & 1 & 0.59 & 0.268 & 6 \\
\hline Switzerland & 2 & 0 & 1 & 0.32 & -1.060 & 13 \\
\hline United Kingdom & 5 & 1 & 0 & 0.82 & 1.809 & 1 \\
\hline Factor loadings & 0.772 & 0.771 & -0.874 & 0.853 & \multicolumn{2}{|c|}{$\begin{array}{c}\text { Eigen value: } \\
2.681\end{array}$} \\
\hline
\end{tabular}

Investor protection is measured by the anti-director index taken from LaPorta et al. (1998), Source of accounting rules is an indicator variable which equals one if a country has a private sector standards setting body, Financial/tax accounting alignment is an indicator variable which equals one if a country's financial and tax accounting rules are closely aligned, and the Accrual index is taken from Hung (2001) and represents the extent to which a country's accounting rules promote the use of accrual accounting. A factor score of these four institutional variables measures the institutional orientation of a country. Countries with high factor scores are classified as shareholder-oriented and countries with low factor scores as stakeholder-oriented. 
and countries with a low score as more stakeholder-oriented. Table 4.1 shows that the institutional environments in the U.K., Ireland, and The Netherlands are classified as the most shareholder-oriented, whereas Germany, Switzerland, and Italy have the most stakeholder-oriented institutions in my sample. This classification corresponds to other studies classifying countries according to the institutions that influence accounting (e.g., Leuz et al. 2003)

A firm's ownership structure is measured by constructing a Herfindahl index of share ownership concentration using the shareholdings of the eight largest owners. Table 4.2 shows the variation in average ownership concentration across countries. The correlation between the factor score and the average CONCENTRATION per country is $-0.685(\mathrm{p}<0.01)$, which indicates that, on average, the concentration of share

Table 4.2

Ownership concentration across sample countries $(n=26,744)$

\begin{tabular}{|c|c|c|c|c|c|c|}
\hline \multirow[b]{2}{*}{ Country } & \multirow{2}{*}{$\begin{array}{l}\text { Avg. ownership } \\
\text { concentration }\end{array}$} & \multirow[b]{2}{*}{$\mathrm{n}$} & \multicolumn{4}{|c|}{ Quartiles } \\
\hline & & & $1^{\mathrm{st}}$ & $2^{\text {nd }}$ & $3^{\text {rd }}$ & $4^{\text {th }}$ \\
\hline \multirow[t]{2}{*}{ Austria } & 0.274 & 522 & 55 & 31 & 172 & 264 \\
\hline & & & $10.5 \%$ & $5.9 \%$ & $33.0 \%$ & $50.6 \%$ \\
\hline \multirow[t]{2}{*}{ Belgium } & 0.182 & 630 & 78 & 87 & 260 & 205 \\
\hline & & & $12.4 \%$ & $13.8 \%$ & $41.3 \%$ & $32.5 \%$ \\
\hline \multirow[t]{2}{*}{ Finland } & 0.134 & 838 & 168 & 272 & 244 & 154 \\
\hline & & & $20.0 \%$ & $32.5 \%$ & $29.1 \%$ & $18.4 \%$ \\
\hline \multirow[t]{2}{*}{ France } & 0.285 & 3764 & 493 & 272 & 1149 & 1850 \\
\hline & & & $13.1 \%$ & $7.2 \%$ & $30.5 \%$ & $49.1 \%$ \\
\hline \multirow[t]{2}{*}{ Germany } & 0.314 & 3897 & 564 & 428 & 1143 & 1762 \\
\hline & & & $14.5 \%$ & $11.0 \%$ & $29.3 \%$ & $45.2 \%$ \\
\hline \multirow[t]{2}{*}{ Ireland } & 0.051 & 374 & 234 & 28 & 95 & 17 \\
\hline & & & $62.6 \%$ & $7.5 \%$ & $25.4 \%$ & $4.5 \%$ \\
\hline \multirow[t]{2}{*}{ Italy } & 0.202 & 1158 & 227 & 125 & 390 & 416 \\
\hline & & & $19.6 \%$ & $10.8 \%$ & $33.7 \%$ & $35.9 \%$ \\
\hline \multirow[t]{2}{*}{ The Netherlands } & 0.147 & 1242 & 165 & 498 & 285 & 294 \\
\hline & & & $13.3 \%$ & $40.1 \%$ & $22.9 \%$ & $23.7 \%$ \\
\hline \multirow[t]{2}{*}{ Norway } & 0.100 & 738 & 242 & 153 & 259 & 84 \\
\hline & & & $32.8 \%$ & $20.7 \%$ & $35.1 \%$ & $11.4 \%$ \\
\hline \multirow[t]{2}{*}{ Portugal } & 0.205 & 429 & 121 & 7 & 105 & 196 \\
\hline & & & $28.2 \%$ & $1.6 \%$ & $24.5 \%$ & $45.7 \%$ \\
\hline \multirow[t]{2}{*}{ Spain } & 0.179 & 996 & 352 & 109 & 269 & 266 \\
\hline & & & $35.3 \%$ & $10.9 \%$ & $27.0 \%$ & $26.7 \%$ \\
\hline \multirow[t]{2}{*}{ Sweden } & 0.076 & 1205 & 318 & 466 & 323 & 98 \\
\hline & & & $26.4 \%$ & $38.7 \%$ & $26.8 \%$ & $8.1 \%$ \\
\hline \multirow[t]{2}{*}{ Switzerland } & 0.148 & 1300 & 236 & 404 & 369 & 291 \\
\hline & & & $18.2 \%$ & $31.1 \%$ & $28.4 \%$ & $22.4 \%$ \\
\hline United & 0.067 & 9651 & 3435 & 3805 & 1622 & 789 \\
\hline Kingdom & & & $35.6 \%$ & $39.4 \%$ & $16.8 \%$ & $8.2 \%$ \\
\hline
\end{tabular}


ownership is lower in shareholder-oriented than in stakeholder-oriented countries. Ownership structures are partially shaped by the institutional environment of the country of domicile. For example, when protection of minority investors' rights is high, equity markets tend to be well-developed and share ownership will likely be dispersed. Concentration of share ownership is a rational response to weak investor protection, as dispersed shareholders are subject to expropriation attempts by insiders to the firm when protection of minority investors' rights is poor (La Porta et al. 1999).

Table 4.3

Descriptive statistics $(n=26,744)$

\begin{tabular}{lrrrrr}
\hline Variable & Mean & $\begin{array}{c}\text { Standard } \\
\text { deviation }\end{array}$ & Q1 & Median & Q3 \\
\hline Ownership variables & & & & & \\
CONCENTRATION & 0.164 & 0.223 & 0.007 & 0.062 & 0.251 \\
WH & 0.375 & - & - & - & - \\
Largest shareholder & 0.294 & 0.262 & 0.075 & 0.230 & 0.499 \\
Financial variables & & & & & \\
ASSETS & 1,806 & 7,459 & 57 & 191 & 801 \\
SALES & 1,592 & 6,111 & 65 & 208 & 819 \\
ASALES & 0.019 & 0.153 & -0.057 & 0.010 & 0.087 \\
ACCR & -0.001 & 0.052 & -0.027 & 0.000 & 0.026 \\
OCF & 0.033 & 0.083 & -0.007 & 0.037 & 0.080 \\
ROA & 0.033 & 0.065 & 0.009 & 0.037 & 0.069 \\
BTM & 0.782 & 0.546 & 0.394 & 0.639 & 1.019 \\
LEVERAGE & 0.126 & 0.126 & 0.020 & 0.096 & 0.190 \\
\hline
\end{tabular}

The variables are defined as follows:

CONCENTRATION = Herfindahl concentration index of control rights;

WH $\quad=$ Indicator variable equal to 1 if a firm is a widely held;

ASSETS $\quad=$ End-of-year total assets (in millions of Euros);

SALES $\quad=$ Sales (in millions of Euros);

$\triangle$ SALES $\quad=$ Change in sales in year $t$, defined as sales in year $t$, scaled by end-of-year total assets, minus sales in year $t-1$, scaled by beginning-of-year total assets;

ACCR $=$ Working capital accruals in year $t$, defined as non-cash working capital in year $t$, scaled by end-of-year total assets, minus non-cash working capital in year $t-1$, scaled by beginning-of-year total assets;

OCF $\quad=$ Operating cash flow in year $t$, defined as net income in year $t$, scaled by end-of-year total assets, minus $\mathrm{ACCR}_{\mathrm{t}}$;

ROA $=$ Return on assets in year $t$, defined as the ratio of net income before extraordinary items in year $t$ to end-of-year total assets;

BTM $=$ Book to market ratio in year $t$, defined as the ratio of end-of-year book value of equity to end-of-year market value of equity;

LEVERAGE $\quad=$ The ratio of end-of-year long-term debt to end-of-year total assets.

I report descriptive statistics for $A C C R, O C F, R O A$, and $\triangle S A L E S$ after removing the top and bottom one percent of the corresponding distributions. 
Partitioning the full sample into quartiles based on ownership concentration shows that not only the across-country variation is large. There is also substantial within-country variation in ownership structures. In countries that I classify as having the most shareholder-oriented institutions, Ireland and the U.K., a substantial number of firms can be classified as closely held, whereas in countries that I classify as most stakeholder-oriented, a sizable number of firms are widely held.

Table 4.3 shows descriptive statistics of the main variables of interest and control variables that I include in the regression. The three ownership variables reported show that there is substantial variation in the pattern of share ownership in the full sample. Furthermore, the firms included in the sample show large differences in relevant control variables such as size, profitability, book-to-market ratios, and leverage.

\subsubsection{Smoothing}

Earnings smoothing manifests itself through a negative relation between accruals and cash flows (Leuz et al. 2003). Although, as discussed in chapter 3, the negative relation between accruals and cash flows is a property of accounting recognition and matching rules, I interpret a more negative association as evidence of active earnings smoothing. To test the influence of institutional factors and firms' ownership structures on earnings smoothing behavior, I estimate the following regression equation:

$$
\begin{aligned}
& A C C R_{t}=\beta_{0}+\beta_{1} O C F_{t}+\beta_{2} O C F_{t} \times C O N C E N T R A T I O N_{t}^{Q 2}+ \\
& \beta_{3} O C C F_{t} \times C O N C E N T R A T I O N_{t}^{Q 3}+\beta_{4} O C F_{t} \times C O N C E N T R A T I O N_{t}^{Q 4}+ \\
& \beta_{5} O_{C C F_{t}} \times \text { ORIENT }+\beta_{6} O_{C C F_{t}} \times \text { ORIENT } \times \text { CONCENTRATION }{ }_{t}{ }^{2}+ \\
& \beta_{7} \mathrm{OCF}_{t} \times \text { ORIENT } \times \mathrm{CONCENTRATION}_{t}{ }^{Q 3}{ }_{t}+ \\
& \beta_{8} O C C F_{t} \times \text { ORIENT } \times \text { CONCENTRATION }{ }_{t}^{Q 4}+ \\
& \beta_{9} \text { ORIENT }+\beta_{10} \Delta S A L E S_{t}+\beta_{11} S_{S A L E S G R O W T H}{ }_{t+1}+\beta_{12} O_{C C F} \times S I Z E_{t}+ \\
& \sum_{k=1}^{11} \kappa_{k} O C F_{t} \times I N D U S T R Y_{t-k}+\sum_{l=1}^{11} \lambda_{l} O C F_{t} \times Y E A R_{t-l}+\varepsilon_{t}
\end{aligned}
$$

where:

$A C C R_{t} \quad=$ Working capital accruals in year $t$, defined as non-cash working capital in year $t$, scaled by end-of-year total assets, minus non-cash working capital in year $t$-1, scaled by beginning-of-year total assets; ${ }^{7}$

$O C F_{t} \quad=$ Operating cash flow in year $t$, defined as net income in year $t$, scaled by end-of-year total assets, minus $A C C R_{t}$;

CONCENTRATION $_{t}=$ Herfindahl concentration index of control rights in year $t$; 
CONCENTRATION ${ }_{t}^{Q n}$ is an indicator variable that equals 1 if the firm-year observation falls into the $n^{\text {th }}$ quartile of the distribution of CONCENTRATION;

ORIENT

$=$ Factor score representing the institutional orientation of a country, transformed to range between 0 and 1 , where high values indicate a shareholder orientation and low values indicate a stakeholder orientation.

$\triangle S A L E S_{t} \quad=$ Change in sales in year $t$, defined as sales in year $\mathrm{t}$, scaled by end-of-year total assets, minus sales in year $t$-1, scaled by beginning-of-year total assets;

SALESGROWTH $H_{t+1}=$ Percentage change in sales from year $t$ to year $t+1$;

$S I Z E_{t} \quad=$ Natural logarithm of end-of-year total assets;

INDUSTRY $_{t} \quad=$ Industry dummies based on the industry classification of Barth et al. (1998);

$Y_{t} \quad=$ Year dummies.

Following chapter 3, I expect the degree of earnings smoothing to be positively related to ownership concentration, i.e. the coefficients on the interaction of $O C F$ and the CONCENTRATION indicator variables are expected to be negative. The effect of a country's institutional orientation on accounting properties is hypothesized to be greater for closely held than for widely held firms. If institutions have an effect on widely held firms' financial reporting choices, the coefficient on OCF $\times$ ORIENT, which measures the effect of ORIENT for the most widely held firms (i.e., firm-year observations in the first quartile of the distribution of CONCENTRATION), is expected to be positive. The coefficients on the three-way interactions of $O C F, O R I E N T$, and the CONCENTRATION indicator variables are expected to be positive, because I hypothesize the effect of institutions to be more pronounced for firms with more concentrated ownership structures.

ORIENT is included to control for differences in accruals across institutional environments. $\triangle S A L E S_{t}$ controls for the non-discretionary part of working capital accruals. I include SALESGROWTH $H_{t+1}$ to control for investments in working capital to facilitate future growth (Dechow et al. 2003). The interaction between $O C F$ and SIZE controls for possible size effects in the accruals-cash flow relation. Finally, interactions of $O C F$ with industry and year dummies control for differences in smoothing behavior across industries or years. To correct for the influence of positive correlation in OLS residuals across years on standard errors, I estimate equation (1) using heteroskedasticity and autocorrelation consistent standard errors (Newey and West 1987). 


\subsubsection{Conservatism}

Consistent with chapter 3 and following Ahmed et al. (2002), I define (unconditional) conservatism as a persistent difference between the market value and the book value of equity. To study the impact of institutions and ownership structure on conservatism, I therefore estimate the following regression equation:

$$
\begin{aligned}
& \text { BTM }_{t}=\beta_{0}+\beta_{1} \text { CONCENTRATION }_{t}^{Q 2}+\beta_{2} \text { CONCENTRATION }_{t}^{Q 3}+ \\
& \beta_{3} \text { CONCENTRATION }{ }_{t}^{Q 4}+\beta_{4} \text { ORIENT }+\beta_{5} \text { ORIENT } \times \text { CONCENTRATION }_{t}^{Q 2}+ \\
& \beta_{6} \text { ORIENT } \times \text { CONCENTRATION }{ }_{t}^{Q 3}{ }_{t}+\beta_{7} \times \text { ORIENT } \times \text { CONCENTRATION }{ }_{t}{ }^{Q 4}+ \\
& \beta_{8} \text { SIZE }_{t}+\beta_{9} \text { SALESGROWTH }_{t}+\beta_{10} \text { ROA }_{t}+\beta_{11} \text { LEVERAGE }_{t}+ \\
& \beta_{12} \text { DIVIDENDS }_{t}+\beta_{13} S T D_{-} R O A_{t}+\sum_{d=0}^{3} \delta_{d} R E T_{t-d}+\sum_{g=0}^{3} \gamma_{g} G W_{t-g}+ \\
& \sum_{k=1}^{11} \kappa_{k} \operatorname{INDUSTR}_{k, t}+\sum_{l=1}^{10} \lambda_{l} \text { YEAR }_{l, t}+\varepsilon_{t}
\end{aligned}
$$

where:

$B T M_{t}$

$=$ Book to market ratio in year $t$, defined as the ratio of end-ofyear book value of equity to end-of-year market value of equity;

SALESGROWTH $H_{t} \quad=$ Percentage change in sales from year $t$ - 1 to year $t$;

$R O A_{t}$

$=$ Return on assets in year $t$, defined as the ratio of net income before extraordinary items in year $t$ to end-of-year total assets;

LEVERAGE $\quad=$ The ratio of end-of-year ratio of long-term debt to end-ofyear total assets;

DIVIDENDS $\quad$ = Dividends declared out of year $t$ net income, scaled by endof-year total assets;

$S T D_{-} R O A_{t} \quad=$ The standard deviation of $R O A_{t}, R O A_{t-1}$, and $R O A_{t-2}$ (if available);

$R E T_{t} \quad=$ Stock return over the twelve month period ending at year $t$ fiscal year-end;

$G W_{t} \quad=$ Goodwill write-off against equity in year $t$ scaled by current end-of-year market value;

and other variables are as defined before.

The coefficients on the CONCENTRATION indicator variables are expected to be negative because, following chapter 3 , closely held firms are expected to report more stakeholder-oriented than widely held firms. The coefficients on the interaction terms between ORIENT and the CONCENTRATION indicator variables are 
hypothesized to be positive, as the effect of ORIENT is expected to be greater for closely held firms than for widely held firms.

Following Ahmed et al. 2002, I include the control variables SIZE, SALESGROWTH ROA, LEVERAGE, DIVIDENDS, and STD_ROA because they represent additional explanations for conservatism. I also control for differences between book and market values caused by lagged recognition by including current and past returns as proxies for past performance (Beaver and Ryan 2000). To control for international differences in the treatment of acquisition goodwill (e.g., writing off against equity immediately or capitalization and amortization) I include current and past goodwill write-offs. This makes sure that international differences in conservatism are not driven by differences in goodwill treatment. Again, I include industry and year dummies to control for industry and year effects. Because OLS residuals of equation (2) could be positively correlated across years, I calculate all tstatistics using heteroskedasticity and autocorrelation consistent standard errors (Newey and West 1987).

\subsection{Results}

\subsubsection{Smoothing test}

Table 4.4 shows the results of estimating equation (4.1). I do not find an effect of ownership concentration on earnings smoothing behavior. This means that in a sample pooled across countries, earnings smoothing does not significantly differ across firms with different ownership structures. The significantly positive coefficient on $O C F \times$ ORIENT ( $<0.01$ one-sided) indicates that a country's institutional orientation has a significant effect on the most widely held firms' reporting behavior. This suggests that widely held firms in stakeholder-oriented countries smooth their earnings more actively than their counterparts in shareholder-oriented countries. The coefficients on the interactions between OCF, ORIENT, and the CONCENTRATION indicator variables are all insignificant, indicating that the effect of ORIENT does not depend on a firm's ownership structure, i.e. widely held and closely held firms are equally affected by institutions.

The fact that earnings smoothing behavior appears to be solely driven by a country's institutional orientation and is not significantly influenced by firms' ownership structures could be explained by tax motives for earnings smoothing. Coppens and Peek (2005) suggest that earnings management activities in countries where the alignment between tax and financial accounting is high (one of the measures in my factor score) are directed at managing tax burdens. Firms in these countries prefer less volatile earnings and are likely to smooth earnings to a greater extent than firms in countries where tax and financial accounting rules are not strongly aligned 
(Ball et al. 2000; Hermann and Inoue 1996). In stakeholder-oriented countries, the benefits from smoothing earnings for tax management may outweigh the benefits of reporting informatively, even for widely held firms.

The control variables $\triangle S A L E S$ and next year's SALESGROWTH are significant and have the predicted signs $(\mathrm{p}<0.01$, one-sided), i.e. working capital accruals are positively related to increases in sales and to future sales growth, which suggests investments in working capital to finance current and future growth. Firm size has a significantly negative coefficient ( $\mathrm{p}<0.01$, two-sided), which indicates either that large firms more actively smooth earning or that large firms have naturally more stable earnings patterns, for example because their operations are more diversified on average.

\subsubsection{Conservatism test}

The results of estimating equation (4.2) are displayed in Table 4.5. The coefficients on the CONCENTRATION indicator variables are all significantly negative. Specifically, firm-year observations in the first quartile of ownership concentration (the most widely held firms) show less conservative reporting behavior than the second $(\mathrm{p}<0.10$,

\section{Table 4.4}

OLS regression analysis of the influence of institutional orientation and ownership concentration on the relationship between cash flows and working capital accruals

\begin{tabular}{|c|c|c|}
\hline Independent variable & Expected sign & $\begin{array}{l}\text { Coefficient } \\
\text { (t-statistic) }\end{array}$ \\
\hline Intercept & $?$ & $\begin{array}{c}0.011 \\
(18.275)^{+++}\end{array}$ \\
\hline $\mathrm{OCF}_{\mathrm{t}}$ & - & $\begin{array}{c}-0.440 \\
(-15.734)^{* * *}\end{array}$ \\
\hline $\mathrm{OCF}_{\mathrm{t}} \times \mathrm{CONCENTRATION}_{\mathrm{t}}^{\mathrm{Q} 2}$ & - & $\begin{array}{c}0.016 \\
(0.494)\end{array}$ \\
\hline $\mathrm{OCF}_{\mathrm{t}} \times \mathrm{CONCENTRATION}_{\mathrm{t}}^{\mathrm{Q} 3}$ & - & $\begin{array}{c}-0.014 \\
(-0.553)\end{array}$ \\
\hline $\mathrm{OCF}_{\mathrm{t}} \times \mathrm{CONCENTRATION}_{\mathrm{t}}^{\mathrm{Q} 4}$ & - & $\begin{array}{c}-0.032 \\
(-1.215)\end{array}$ \\
\hline $\mathrm{OCF}_{\mathrm{t}} \times \mathrm{ORIENT}$ & $?$ & $\begin{array}{l}0.220 \\
(8.476)^{* * *}\end{array}$ \\
\hline $\mathrm{OCF}_{\mathrm{t}} \times \mathrm{ORIENT} \times \mathrm{CONCENTRATION}_{\mathrm{t}}^{\mathrm{Q} 2}$ & + & $\begin{array}{c}-0.030 \\
(-0.810)\end{array}$ \\
\hline $\mathrm{OCF}_{\mathrm{t}} \times \mathrm{ORIENT} \times \mathrm{CONCENTRATION}_{\mathrm{t}}^{\mathrm{Q3}}$ & + & $\begin{array}{l}-0.0481 \\
(-1.336)\end{array}$ \\
\hline $\mathrm{OCF}_{\mathrm{t}} \times \mathrm{ORIENT} \times \mathrm{CONCENTRATION}_{\mathrm{t}}{ }^{\mathrm{Q}}$ & + & $\begin{array}{c}-0.009 \\
(-0.230)\end{array}$ \\
\hline
\end{tabular}


one-sided), third ( $p<0.05$, one-sided), and fourth quartiles $(\mathrm{p}<0.01$, one-sided). The difference between the two center quartiles is insignificant, but the most closely held firms report significantly more conservative than firms in the third quartile $(p<0.01$, one-sided). Overall, this suggests that the stakeholder orientation of a firm's reporting

Table 4.4 (Continued)

\begin{tabular}{lcc}
\hline Independent variable & Expected sign & $\begin{array}{c}\text { Coefficient } \\
\text { (t-statistic) }\end{array}$ \\
\hline $\begin{array}{l}\text { Control variables } \\
\text { ORIENT }\end{array}$ & $?$ & -0.000 \\
& & $(-0.013)$ \\
SALES $_{\mathrm{t}}$ & + & 0.011 \\
SALESGROWTH $_{\mathrm{t}+1}$ & + & $(5.211)^{* * *}$ \\
OCF $_{\mathrm{t}} \times$ SIZE' $_{\mathrm{t}}^{\prime}$ & $?$ & 0.017 \\
& & $(9.494)^{* * *}$ \\
Number of observations & & -0.015 \\
F-value & & $(-5.400)^{+++}$ \\
Adjusted R & & 24,312 \\
\hline
\end{tabular}

The variables are defined as follows:

$\mathrm{ACCR}_{\mathrm{t}} \quad=$ Working capital accruals in year $t$, defined as non-cash working capital minus provisions in year $t$, scaled by end-of-year total assets, minus noncash working capital minus provisions in year $t$-1, scaled by beginning-ofyear total assets;

$\mathrm{OCF}_{\mathrm{t}} \quad=$ Operating cash flow in year $t$, defined as net income in year $t$, scaled by end-of-year total assets, minus $\mathrm{ACCR}_{\mathrm{t}}$;

CONCENTRATION $_{\mathrm{t}}=$ Herfindahl concentration index of control rights in year $t$; CONCENTRATION $_{t}^{Q n}$ is an indicator variable that equals 1 if the firmyear observation falls into the $n^{\text {th }}$ quartile of the distribution of CONCENTRATION;

ORIENT $=$ Factor score representing the institutional orientation of a country, transformed to range between 0 and 1 , where high values indicate a shareholder orientation and low values indicate a stakeholder orientation;

$\triangle$ SALES $_{\mathrm{t}} \quad=$ Change in sales in year $t$, defined as sales in year $\mathrm{t}$, scaled by end-of-year total assets, minus sales in year $t-1$, scaled by beginning-of-year total assets;

SALESGROWTH $_{\mathrm{t}+1}=$ Percentage change in sales from year $t$ to year $t+1$;

SIZE $_{\mathrm{t}}^{\prime} \quad=$ Mean-centered natural logarithm of end-of-year total assets.

Coefficients on interactions between $O C F$ and industry and year dummies are included in the regression but not separately reported. The manufacturing industry and the most recent available year are used as the base categories. I estimate the regression after removing the top and bottom one percent of the distribution of $A C C R$ and $O C F$. Reported t-statistics are based on heteroskedasticity and autocorrelation consistent standard errors (Newey and West 1987).

$* * *, * *$, and $*\left({ }^{++},+{ }^{++}\right.$, and $\left.{ }^{+}\right)$denotes statistical significance at the 1,5 , and 10 percent one-tailed (twotailed) alpha level, respectively. 
increases with its concentration of share ownership.

The coefficient on ORIENT is not significant which indicates that the most widely held firms' level of conservatism is not influenced by a country's institutional orientation. The significantly negative coefficients on ORIENT $\times$ CONCENTRATION ${ }^{Q 2} \quad(\mathrm{p}<0.10$, one-sided $)$ and ORIENT $\times$ CONCENTRATION $^{Q 3}$ $(\mathrm{p}<0.01$, one-sided) show that the influence of institutions on conservatism of firms in the second and third quartiles of the distribution of ownership concentration is more pronounced than for the most widely held firms in my sample. Also, the influence of institutions on the most closely held firms in my sample (the fourth quartile of CONCENTRATION) is significantly greater than the influence on firms in the first, second, and third (all $\mathrm{p}<0.01$, one-sided) quartiles of ownership concentration. ${ }^{8}$ In summary, these results are consistent with the hypothesis that the effect of a country's institutional orientation on financial reporting becomes more influential when a firm's ownership concentration increases.

SIZE has a significantly negative coefficient $(\mathrm{p}<0.01$, two-sided $)$, which indicates that larger firms report more conditionally conservative, possibly because of higher political costs. Furthermore, I find that SALESGROWTH and ROA are significantly positively ( $\mathrm{p}<0.01$ and $\mathrm{p}<0.05$, one-sided, respectively) associated with conservatism, which could be explained by the relatively higher cost for low

\section{Table 4.5}

OLS regression analysis of the influence of institutional orientation and ownership concentration on a market-based measure of accounting conservatism

\begin{tabular}{|c|c|c|}
\hline Independent variable & Expected sign & $\begin{array}{l}\text { Coefficient } \\
\text { (t-statistic) }\end{array}$ \\
\hline Intercept & + & ${ }^{1.522}$ \\
\hline CONCENTRATION $_{\mathrm{t}}^{\mathrm{Q} 2}$ & - & $\begin{array}{l}-0.039 \\
(-1.615)^{*}\end{array}$ \\
\hline CONCENTRATION $_{\mathrm{t}}^{\mathrm{Q} 3}$ & - & $\begin{array}{l}-0.049 \\
(-2.101)^{* *}\end{array}$ \\
\hline CONCENTRATION $_{\mathrm{t}}^{\mathrm{Q} 4}$ & - & $\begin{array}{l}-0.129 \\
(-5.642)^{* * *}\end{array}$ \\
\hline ORIENT & $?$ & $\begin{array}{c}0.019 \\
(0.807)\end{array}$ \\
\hline ORIENT $\times$ CONCENTRATION $_{t}{ }^{\mathrm{Q} 2}$ & + & $\begin{array}{c}0.045 \\
(1.463)^{*}\end{array}$ \\
\hline ORIENT $\times$ CONCENTRATION $_{t}{ }^{\mathrm{Q} 3}$ & + & $\begin{array}{l}0.132 \\
(4.063)^{* * *}\end{array}$ \\
\hline ORIENT $\times$ CONCENTRATION ${ }_{t}^{\text {Q4 }}$ & + & $\begin{array}{l}0.273 \\
(7.546)^{* * *}\end{array}$ \\
\hline
\end{tabular}




\begin{tabular}{lcc}
\hline Independent variable & Expected sign & $\begin{array}{c}\text { Coefficient } \\
(\mathrm{t}-\text { statistic })\end{array}$ \\
\hline $\begin{array}{l}\text { Control variables } \\
\text { SIZE }_{\mathrm{t}}\end{array}$ & $?$ & -0.032 \\
SALESGROWTH $_{\mathrm{t}}$ & - & $-11.514)^{* * *}$ \\
ROA $_{\mathrm{t}}$ & - & -0.165 \\
LEVERAGE $_{\mathrm{t}}$ & - & $-0.185)^{* * *}$ \\
DIVIDENDS $_{\mathrm{t}}$ & - & $(-2.315)^{* *}$ \\
STD_ROA $_{\mathrm{t}}$ & - & -0.093 \\
& & $-1.147)^{* *}$ \\
Number of observations & & -6.721 \\
F-value & & $-1.488)^{* * *}$ \\
Adjusted ${ }^{2}$ & & $(-12.886)^{* * *}$ \\
\hline
\end{tabular}

The variables are defined as follows:
$\mathrm{BTM}_{\mathrm{t}} \quad=$ Book to market ratio in year $t$, defined as the ratio of end-of-year book value of equity to end-of-year market value of equity;
CONCENTRATION $_{\mathrm{t}}=$ Herfindahl concentration index of control rights in year $t$; CONCENTRATION $_{t}^{Q n}$ is an indicator variable that equals 1 if the firm- year observation falls into the $n^{\text {th }}$ quartile of the distribution of CONCENTRATION;
ORIENT $=$ Factor score representing the institutional orientation of a country, transformed to range between 0 and 1 , where high values indicate a
SIZE $_{\mathrm{t}} \quad=$ Natural logarithm of end-of-year total assets;
SALESGROWTH $_{\mathrm{t}}=$ Percentage change in sales from year $t$-1 to year $t$
$\mathrm{ROA}_{\mathrm{t}} \quad=$ Return on assets in year $t$, defined as the ratio of net income before extraordinary items in year $t$ to end-of-year total assets;
LEVERAGE $_{\mathrm{t}}$
DIVIDENDS $_{\mathrm{t}}$
$=$ The ratio of end-of-year liabilities to end-of-year total assets;
$=$ Dividends declared out of year $t$ net income, scaled by end-of-year total assets;
STD_ROA $=$ The standard deviation of $\mathrm{ROA}_{\mathrm{t}}, \mathrm{ROA}_{\mathrm{t}-1}$, and $\mathrm{ROA}_{\mathrm{t}-2}$ (if available);
$\mathrm{RET}_{\mathrm{t}} \quad=$ Stock return over the twelve month period ending at year $t$ fiscal year-end.

Coefficients on industry dummies, year dummies, $R E T_{t}, R E T_{t-1}, R E T_{t-2}$, and $R E T_{t-3}$, and $G W_{t}, G W_{t-1}$, $G W_{t-2}$, and $G W_{t-3}$ are included in the regression but not separately reported. The manufacturing industry and the most recent available year are used as the base categories. I estimate the regression after removing the top and bottom one percent of the distribution of BTM. Reported t-statistics are based on heteroskedasticity and autocorrelation consistent standard errors (Newey and West 1987). $* * *, * *$, and ${ }^{*}\left({ }^{+++},{ }^{++}\right.$, and $\left.{ }^{+}\right)$denotes statistical significance at the 1,5 , and 10 percent one-tailed (twotailed) alpha level, respectively. 
profitability firms to understate net income. LEVERAGE, DIVIDENDS, and STD_ROA are included to control for bondholder-shareholder conflicts over dividend policy, and, as hypothesized by Ahmed et al. (2000), are significantly negative $(\mathrm{p}<0.05, \mathrm{p}<0.01$, and $\mathrm{p}<0.01$, one-sided, respectively). The coefficients on current and lagged returns (untabulated), which are included to control for lagged recognition of economic income in accounting income are all significantly negative $(\mathrm{p}<0.01)$, as predicted. Also, the coefficients on current and lagged goodwill write-offs (untabulated), which control for differences in book and market values caused by immediate write-offs of goodwill, are all significantly negative $(\mathrm{p}<0.01)$.

\subsubsection{Sensitivity analyses}

1. Alternative measure of ownership structure: To test the sensitivity of my results to the definition of ownership structure, I replace the CONCENTRATION indicator variables by the continuous variable CONCENTRATION in equations (4.1) and (4.2). The results (not tabulated) remain qualitatively similar.

2. Alternative definition of accruals: To test whether the definition of accruals drives the results, I estimate equation (4.1) while substituting working capital accruals by total accruals (i.e., including depreciation). ${ }^{9}$ The results for my smoothing test (not tabulated) remain qualitatively similar. However, the coefficient on ORIENT becomes negative and statistically significant, whereas I do not find a significant effect in my main analysis (see Table 4.4). This could suggest that depreciation expense (the only difference between the two accrual measures) is driven by a country's institutional orientation, i.e. that firms from countries with more shareholder-oriented institutions report greater depreciation expenses.

\subsection{Discussion and concluding remarks}

In this chapter I study the influence of country-specific institutional factors on firms' financial reporting choices at different levels of ownership concentration. I find some evidence that the influence of institutions on financial reporting is more pronounced for closely held firms than for widely held firms. Specifically, I find that the extent to which widely held firms engage in (unconditionally) conservative reporting does not differ across institutional environments, whereas closely held firms in shareholderoriented countries display significantly less conservative reporting behavior than their counterparts in stakeholder-oriented countries. Furthermore, I find that differences in earnings smoothing across countries are related to a country's institutional orientation. However, contrary to expectations, I do not find a difference in the effect of institutions for firms with different levels of ownership concentration. A possible explanation for this finding is that both closely held and widely held firms in 
stakeholder-oriented institutional environments, where financial and tax accounting tend to be highly aligned, smooth earnings in order to manage their tax burdens.

The analyses in this chapter refine previous international accounting research by documenting that the influence of institutions on some properties of accounting information may differ across firms. Specifically, the finding that in stakeholderoriented institutional settings, the variation in (unconditional) conservatism across firms is greater than in shareholder-oriented settings, suggest that existing studies of international differences in accounting are better predicting financial reporting behavior in the latter type of environments.

Mandated IFRS introduction for listed EU firms from 2005 on can be seen as an attempt by the European Commission to make reporting in the EU more shareholderoriented. The findings in this chapter suggest that changes that make the institutional environment more shareholder-oriented reduce the influence of ownership concentration on financial reporting, which makes the reporting objectives of firms more homogeneous. In chapter 3, I find that in The Netherlands, a country with shareholder-oriented accounting regulation that is close to IFRS, firms' ownership structures significantly influence financial reporting. Taken together, these findings suggests that mere standardization of accounting regulation is not likely to result in more homogeneity in financial reporting and that other institutional changes are necessary to make financial reporting practices more homogeneous and more shareholder-oriented. 


\section{Notes}

1 I split up firm-years into quartiles based on ownership concentration.

2 Prior international accounting research has dichotomized countries' accounting systems using differing terminology. For example, Ali and Hwang (2000) distinguish between bank- and marketoriented countries, whereas Ball et al. (2000) classify countries according to their legal origins into code- and common law countries. Leuz et al. (2003) use the 'insider' versus 'outsider' classification, but point out that their classification shows a large degree of overlap with other classifications.

3 Tucker and Zarowin (2006) argue that earnings smoothing is informative in the sense that it improves the predictability of firms' earnings.

4 Leuz et al. (2003) compare countries' institutional environments on different characteristics and show, using a cluster analysis, that 'outsider' institutional environments differ from 'insider' institutional environments by, among others, having a higher stock market capitalization, more listed firms, a higher number of IPOs, lower average ownership concentration, a higher antidirector rights index, and a higher disclosure index. My classification is likely to show considerable overlap with other classifications of countries' institutional environments.

5 Ownership data from Faccio and Lang (2002) is available from the web site of the Journal of Financial Economics (http://jfe.rochester.edu/data.htm)

6 Unlike in chapter 3, where separate measures for the use of takeover defense mechanisms, including the use of depository receipts, are considered, I include depository receipt holdings (shares are held by administrative offices) in my ownership measures in this chapter.

7 Hribar and Collins (2002) indicate that an artificial negative correlation between accruals and cash flows could be created if (i) cash flows are defined as earnings minus accruals and (ii) if mergers and acquisitions, discontinued operations, or exchange rate changes affect balance sheet items. A potential solution to this problem is to use accruals and cash flows from the firms' cash flow statements. However, because I do not have such data available, I use an alternative solution by scaling working capital in year $t(t-1)$ by total assets from the same year $t(t-1)$ and calculating working-capital accruals as changes in scaled working capital. This contrasts with the commonly used approach of defining accruals as changes in working capital in year $t$, scaled by total assets from year $t-1$. Because working capital and total assets from one particular year are similarly affected by events such as mergers and acquisitions, scaling working capital by total assets from the same year should reduce the distorting effect of the problems described by Hribar and Collins.

8 The effect of a country's institutional orientation differs significantly between quartiles 1 and 2 ( $p<0.05$, one-sided), 2 and 3 ( $p<0.01$, one-sided), and 3 and $4(p<0.01$, one-sided).

9 I do not use an abnormal accruals measurement model, as in Chapter 3, to decompose accruals into a normal (non-discretionary) and abnormal (discretionary) part, because Meuwissen et al. (2006) show that the performance of these models shows considerable cross-country variation. 



\section{Chapter 5}

\section{Summary and Conclusion}

\subsection{Introduction}

This dissertation examines determinants of firms' financial reporting choices. In chapter 2 the determinants and consequences of non-local GAAP adoption by EU firms are studied. Chapters 3 and 4 examine the effects of institutional and firmspecific factors on properties of accounting information. In chapter 3 I study the effects of firm-specific reporting incentives generated by firms' governance structures in detail and in chapter 4 I consider the effects of both country-specific and firmspecific factors on reporting as well as their interactive effect. This final chapter starts with a summary of the empirical findings of the three studies contained in this dissertation, followed by conclusions and implications. Finally, I discuss some limitations and provide suggestions for future research.

\subsection{Summary}

The study in chapter 2 investigates the determinants and consequences of voluntary adoption of non-local accounting principles (non-local GAAP) by firms listed and domiciled in the European Union. Knowing what drives firms to voluntarily use nonlocal standards helps to understand the costs and benefits of non-local GAAP adoption. Furthermore, analyzing the consequences of adoption sheds light on the existence or absence of measurable benefits of adoption. In the study, I consider the two predominant internationally accepted sets of accounting standards, IAS/IFRS and U.S. GAAP. I use various data sources to identify EU firms that use non-local GAAP of which I subsequently inspect the 1999 annual reports to confirm their usage of IAS/IFRS or U.S. GAAP. Firms' 1999 annual reports are chosen because accounting standard choices in more recent years may be affected by the announcement of the proposal by the European Commission in February 2001 to mandate IAS usage from 2005 on. The maintained hypothesis is that firms that voluntarily adopt IAS or U.S. GAAP expect to experience net benefits from adoption. The finding that 133 non-financial firms in the EU voluntarily use non-local GAAP in 1999 suggests that the vast majority of listed EU firms do not expect to benefit from non-local GAAP adoption. I find that firms voluntarily using non-local GAAP are more likely to be listed on a U.S. exchange, the EASDAQ exchange in Brussels, and have more 
geographically dispersed operations. Furthermore, they are more likely to be domiciled in a country with lower quality financial reporting and where IAS is explicitly allowed as an alternative to local GAAP.

In the second part of chapter 2, I study whether non-local GAAP adopters have lower levels of information asymmetry, a much cited benefit of using more transparent financial reporting, than non-adopters. I consider several proxies for information asymmetry: analyst following, cost of equity capital, and uncertainty among analysts and investors (measured by analyst forecast dispersion and stock return volatility). I document a positive effect of non-local GAAP adoption on analyst following, but fail to find evidence of a lower cost of capital or lower stock return volatility for non-local GAAP adopters. Contrary to expectations, analyst forecast dispersion appears to be higher for firms using IAS or U.S. GAAP than for firms using local GAAP. However, by comparing 'early' and 'late' adopters, I find that only late adopters experience higher forecast dispersion. The forecast dispersion of early adopters and non-adopters is not significantly different. This suggests that benefits of adoption take some time to fully materialize.

In chapter 3, the influence of firms' corporate governance structures on financial reporting is examined. The setting of the study, The Netherlands, is characterized by an institutional environment with shareholder-oriented accounting regulation, which is relatively weakly enforced. These characteristics leave firms considerable reporting discretion. Furthermore, the Dutch corporate governance system has some unique characteristics. First, firms display a large diversity in ownership structures, with some firms being widely held, whereas others are majority owned by management or a single large shareholder. Second, some firms' Supervisory Boards fall under the so-called structure regime, which grants supervisory directors substantial power over managers' appointment and dismissal and financial reporting. Finally, Dutch corporate governance is characterized by the extensive use of various takeover defense mechanisms. This variation in governance structures creates strong variation in (firm-specific) reporting incentives. Coupled with the high degree of reporting discretion that the institutional environment offers, this provides a unique research setting to study the influence of governance structures on properties of financial reporting, while holding institutional factors constant.

I characterize firms' reporting objectives as stakeholder- or shareholderoriented. The stakeholder (shareholder) orientation of a firm's financial reporting is expected to be increasing (decreasing) in the degree of ownership concentration, being subject to the structure regime, and the use of takeover defense mechanisms. Firms with shareholder-oriented governance structures face demand for informative financial reporting from shareholders who are at arm's length from the firm. In firms with stakeholder-oriented governance structures, shareholders typically have access to 
private information and are therefore less dependent on public financial reporting. Furthermore, the market for corporate control tends to be weaker for stakeholderoriented firms. This allows firm management to take the interests of other stakeholders into account and focus financial reporting choices on payout determination and maintain financial stability by avoiding excessive payouts to any group of stakeholders (including shareholders' dividend payments). I hypothesize that firms that I label as stakeholder-oriented smooth earnings more actively and report more (unconditionally) conservative than firms that I label as shareholder-oriented. Smoothed earnings figures and conservative accounting choices ensure financial stability by controlling payouts and ensuring sufficient internal financing. Furthermore, stakeholder-oriented firms are expected to engage less in myopic reporting, measured as meeting or just beating analyst earnings forecasts than shareholder-oriented firms, because of the lower capital market pressures. I find evidence consistent with my hypotheses.

Chapter 4 describes a study about the impact of the effect of a country's institutional orientation on firms' reporting objectives conditional on firms' ownership structures using a sample of firms from Western European countries. This study complements the study in chapter 3, where I study the influence of firms' incentives while holding the institutional environment constant, by investigating the influence of institutions, while controlling for firms' ownership structures. I measure a country's reporting orientation, stakeholder- or shareholder-oriented, by constructing a factor score of various institutional influences on accounting. Firm-specific reporting incentives are measured by share ownership concentration. I hypothesize that institutional influences on reporting are stronger for closely held than for widely held firms. As argued in chapter 3, widely held firms have incentives to report shareholderoriented. In stakeholder-oriented institutional environments, where these reporting incentives are incongruent with the institutional reporting orientation, widely held firms are expected to be able to report shareholder-oriented by choosing certain accounting options or by providing additional disclosures to better inform dispersed shareholders. On the other hand, the costs for closely held firms in shareholderoriented countries of not complying with the country's institutional orientation tend to be relatively high. The strong protection of minority investors' rights and typically strict enforcement of accounting standards are expected to lead to shareholder-oriented reporting also by closely held firms in these countries.

Using the same methodology as in chapter 3, I find that firms' ownership structures moderate the effect of institutions on firms' level of (unconditional) conservatism. Furthermore, I find that institutions influence earnings smoothing behavior. ${ }^{1}$ However, I do not find the hypothesized moderating effect of ownership structure, i.e., closely held and widely held firms' earnings smoothing behavior is equally affected by a country's institutional orientation. In stakeholder-oriented 
institutional environments, the alignment between financial and tax accounting rules, one of the measures included in the institutional orientation factor score, is relatively high. Firms may therefore smooth their earnings to manage taxes in these countries. Finding no difference in smoothing behavior between widely held and closely held firms may indicate that, even for widely held firms, the benefits of income smoothing for tax purposes outweigh the costs of not reporting informatively in stakeholderoriented institutional environments.

\subsection{Limitations and suggestions for future research}

To measure the consequences of adoption of non-local GAAP in chapter 2, I use various proxies for information asymmetry. The mixed evidence regarding adoption consequences could be related to the inability of these measures to accurately measure the level of information asymmetry between firms and their shareholders. Furthermore, relatively little data was available in the post-adoption period. Therefore, I have not been able to thoroughly test the explanation I offer that benefits from adoption take some time to fully materialize, i.e., because investors and analysts need time to fully comprehend the changes brought about by the switch to non-local GAAP. Also, the effects of voluntary non-local GAAP adoption may very well be different from the effect of, for example, the mandated introduction of IAS/IFRS in the EU. Future research could try to better measure the consequences of adoption by using longer time series. Also, the effects of the mandatory EU-wide introduction of IAS/IFRS could be analyzed, keeping in mind that the short-term effects may be different from the long-term consequences.

The studies in chapters 3 and 4 use ownership concentration (chapters 3 and 4), being subject to the structure regime, and the use of takeover defense mechanisms (chapter 3) as firm-specific determinants of financial reporting objectives. Although I argue that these are important determinants, there are several other classes of factors that influence firms' reporting objectives. The measures I study mainly reflect the absence or presence of shareholders' demand for shareholder-oriented reporting. Other groups of stakeholders, like providers of debt financing, may have different reporting demands. Future research could study the effect of specific reporting demands from other stakeholders on properties of firms' accounting.

The empirical proxies for firms' reporting objectives I study in chapters 3 and 4, the accounting properties unconditional conservatism and earnings smoothing, are subject to measurement error. The book to market ratio which I use as an inverse proxy for conservative reporting behavior is influenced by factors not explained by accounting choices. Although I control for some of these factors in a manner consistent with prior literature, I cannot exclude the possibility of correlated omitted 
variables. However, I am not aware of any variable that is correlated with the variables measuring firm-specific and country-specific reporting incentives which is also related to the book to market ratio. Furthermore, because of the unavailability of cash flow statement data for many firms, working capital accruals and operating cash flows have to be calculated using balance sheet data. Calculating accruals using the balance sheet approach is an accepted method in the literature, especially when using international data sets. Future research could assess the robustness of the results by refining the data used or by examining further proxies for firms' reporting objectives.

\subsection{Conclusions and implications}

The study on voluntary non-local GAAP adoption in the EU presented in chapter 2 indicates that only $6.4 \%$ of my sample firms use IAS/IFRS or U.S. GAAP by $1999,{ }^{2}$ which suggest that the net benefits of adoption are negative for the majority of firms. I find that adoption of non-local GAAP is explained by both firm-specific and countryspecific factors. Specifically, adopters are more likely to be listed on the EASDAQ exchange or in the U.S., have more geographically dispersed operations, and are larger. Furthermore, they are more likely to be domiciled in countries where local accounting standards are of relatively low quality and in countries where IAS/IFRS is explicitly allowed as an alternative to local GAAP. Firms with these characteristics are therefore more likely to benefit from adoption and considering the obligation for listed EU firms to use IAS/IFRS from 2005, these are the types of firms that the European Commission is benefiting with the new accounting regulation. Considering that firms that do not voluntarily switch to IAS/IFRS do not expect to experience net benefits from adoption, these firms could have incentives to not fully comply with IAS/IFRS. As such, identification of determinants of non-local GAAP adoption could help enforcement institutions direct their efforts in enforcing the correct application of IAS/IFRS from 2005 on.

Whether mandated adoption of IAS/IFRS will lead to more transparent financial reporting across Europe ultimately remains an open question. From the analysis of consequences of voluntary non-local GAAP adoption in chapter 2 mixed results emerge. Firms using non-local standards (especially 'early' adopters) are followed more heavily by financial analysts. I fail to find evidence of differences in cost of equity capital or stock return volatility. 'Late' adopters even have higher analyst forecast dispersion. However, 'early' adopters are not different from nonadopters with respect to forecast dispersion. This analysis of the consequences of voluntary adoption could suggest that adoption benefits take some time to materialize. Daske (2006) finds that benefits from non-local GAAP adoption, in the form of a lower cost of equity capital, do not seem to be apparent for voluntary adopters. 
Furthermore, results by Armstrong et al. (2007) suggest that the major source of benefits from mandatory IFRS adoption is convergence of financial reporting across firms, besides increased information quality. This would imply that benefits from the introduction of IFRS for financial reporting in the EU may very well be substantial, but that they do not come from improvements in a firms' information environment, but are mainly due to harmonization of financial reporting practice across firms.

The analyses in chapter 3 cast doubt on the achievability of the European Commission's aim of promoting the transparency and comparability of financial reporting by mandating public EU firms to use IAS/IFRS. The results indicate that the firm-specific reporting incentives generated by Dutch firms' governance structures significantly influence their financial reporting behavior. IAS/IFRS standards are similar to the Dutch 'Guidelines for Annual Financial Statements' issued by the 'Council for Annual Reporting' (Raad voor de Jaarverslaggeving), which are followed by all Dutch publicly listed firms. Because of this similarity in accounting regulation, it is questionable whether mandating firms with stakeholder-oriented governance structures to use IAS/IFRS will significantly change these firms' financial reporting.

Chapter 4 extends chapter 3 by studying the influence of institutions at different levels of ownership concentration. The finding that a country's institutional orientation has a greater influence on the level of (unconditional) conservatism for closely held than for widely held firms, suggests that some properties of accounting information are affected differently by institutions across firms with different reporting incentives. This finding is important for regulators in assessing the impact of (changes in) the institutional environment, for example, enforcement or accounting regulation, across firms. The combined results from chapters 3 and 4 suggest that IFRS adoption will be successful in reducing differences in accounting across firms with different reporting incentives if not only accounting regulation is changed, but also other aspects of the institutional environment are changed simultaneously.

Important developments that can significantly influence firms' financial reporting are taking place, both on the EU level and in The Netherlands. The description of Dutch corporate governance in chapter 3 is accurate for the sample period studied. However, some major changes have taken place in recent years. First, important responsibilities of the Supervisory Boards of structure firms, such as the right to amend the financial statements, the approval of key firm decisions, the appointment and dismissal of supervisory directors, and the determination of supervisory directors' remuneration, have been transferred to shareholders. Second, holders of depository receipts are able to exercise their voting rights. However, the holder of the voting rights (typically an administrative office controlled by the firm) can refuse holders of depository receipts to exercise voting rights in the case of a public offer for the firms' shares or depository receipts. Third, the implementation of 
the EU Takeover Directive will reduce the possibility to effectively use takeover defense mechanisms. The 'mandatory offer rule' stipulates that a shareholder with predominant control (defined in the Dutch setting as at least 30 percent of voting rights) is required to make a public offer for the remaining shares. The Netherlands has decided to opt out of articles 9 and 11 (the 'frustrating action' and 'breakthrough' provisions) of the Takeover Directive, which would forbid offeree firms to take defensive action and which would allow a shareholder that has acquired at least 75 percent of a firm's shares through a public offer to be able to break through a firm's takeover defense mechanisms. However, firms can voluntarily adopt these provisions in their Articles of Association. Finally, firms now have to report on their compliance with a number of principles and best practice pronouncements of the Dutch corporate governance code ('Code Tabaksblat') in their annual reports. The Code deals with issues such as the independence of the members of the Supervisory Board, the maximum number of directorships managing and supervisory directors can hold, term limits of directors, and the disclosure of remuneration policies and conflicts of interest of directors.

One of the objectives of stakeholder-oriented reporting is securing sufficient internal financing through earnings smoothing and conservative reporting behavior. However, in the absence of effective takeover defense mechanisms, the substantial cash holdings make these firms attractive takeover targets. The stronger corporate control market that the reform of the Dutch corporate governance system creates leads to considerably more influence from shareholders on management. Politicians, trade unions, and employers' organizations have criticized the consequences of the corporate governance reform. Venture capitalists take a growing interest in Dutch public firms as they are constantly seeking to take over and restructure underperforming firms. In the recent past this has lead to, among others, the privatizations of retail firm VendexKBB and media firm VNU. Critics argue that a disproportionate emphasis is placed on shareholders' interests at the expense of other stakeholders. Shareholders interests are not necessarily congruent with the interests of other stakeholders, as minority shareholders are mainly interested in short-term value creation and not necessarily in the long-term survival of the firm. Furthermore, critics fear that Dutch firms increasingly become owned by foreign investors, which could lead to a loss of employment in The Netherlands. Also the risk that venture capitalists impose on firms is a point of critique, because most privatizations are financed heavily by debt capital.

On the contrary, it can be argued that active shareholders fulfill an important role in monitoring management. A strong market for corporate control forces managers to make decisions that maximize firm value. Likewise, debt capital helps reduce the agency costs of free cash flow (Jensen 1986), because, unlike dividends, the 
non-discretionary nature of interest payments makes debt an effective bonding mechanism. In general, I consider the move towards shareholder-oriented governance structures to be positive. Capital markets have an important role in the efficient channeling of funds, both nationally and internationally. And although governments should try to protect the interests of all parties in society, this role should not be executed by protecting Dutch firms from takeovers. Public firms' financial reporting should serve an important role in reducing agency conflicts between minority shareholders and management by facilitating contracting and providing useful information for valuing investments.

On a European level, several important regulatory changes are taking place that will influence and further harmonize financial reporting across the $E U$. The Transparency Directive harmonizes various disclosure requirements and, among others, requires listed EU firms to publish annual reports within four months after fiscal yearend and to draw up interim financial statements. Furthermore, this Directive regulates disclosures of major shareholdings in listed firms. The Prospectus Directive makes it possible for firms to use a single prospectus on capital markets throughout the EU, which reduces the costs of listing in multiple EU Member States.

The EU's Market Abuse Directive sets uniform rules against insider trading and market manipulation across the EU. The market for corporate control in many EU countries will be strengthened by the abovementioned Takeover Directive, which increases the influence of (minority) shareholders. One of the most important developments however, is the revision of the Eighth Company Law Directive on auditing. The Directive, adopted in April 2006, among others, requires firms to set up an independent audit committee and to publicly disclose audit fees. Furthermore, the Directive requires independence of the auditor and the audited firm, stipulates that audits should be conducted in accordance with International Standards on Auditing (ISA), and regulates the oversight and registration of auditors and audit firms. The Directive thus will further harmonize audit practices in the EU, which can have significant impact on firms' financial reporting choices.

The developments that are taking place are important steps in the direction of making the institutional environment across EU countries more shareholder-oriented. As argued before, institutional reforms are important to make the introduction of IAS/IFRS standards successful. However, progress is rather slow and significant differences remain in important areas. The lengthy endorsement process of the fair value option in IAS 39 by the Accounting Regulatory Committee of the European Commission is illustrative of the difficulties of standardizing financial reporting across all EU member states. Also, Member States are allowed to opt out of articles 9 and 11 of the Takeover Directive. Article 9 forbids firms to take defensive action in the case of a bid without shareholder approval and article 11 allows bidders to breakthrough 
target firms' anti-takeover mechanisms. Many EU countries are not implementing one or both of these articles in national law, which means that the Directive only sets minimum standards but does not fully harmonize the corporate control market.

One of the most important influences on financial reporting that has only recently been addressed on an international level is the enforcement of accounting regulation. The Transparency Directive stipulates that individual Member States are responsible for the enforcement of the correct application of IFRS and sets minimum requirements for national enforcement bodies. Furthermore, the Committee of European Securities Regulators (CESR) issues standards and guidelines to coordinate enforcement practices. However, because the Transparency Directive only is effective from the beginning of 2007, it remains unclear whether measures taken so far will harmonize enforcement of IFRS across the EU in practice.

The institutional changes that are underway have the potential to make reporting in the EU more shareholder-oriented and more comparable across firms. In the short run, I expect that there will be great diversity in the effectiveness of the implementation of IAS/IFRS. As suggested in the analysis of consequences of nonlocal GAAP adoption in chapter 2, investors and other stakeholders will likely need time to learn how to interpret information reported under IFRS and firms will need time to correctly implement the new set of accounting standards. Also, many reforms mentioned above still need to be effectuated and further institutional changes are necessary in many countries. One aspect that I consider essential in achieving comparability of financial reporting information across countries is equally strict enforcement of accounting standards across countries. However, uniform enforcement across countries is still in its infancy and will likely take some years to become fully harmonized. Changes in firm-specific incentive factors, like firms' ownership structures and financing methods, which are partly a result of institutional changes, can be expected to take even longer. When reforms continue along the current path of making both institutions and corporate governance more shareholder-oriented, financial reporting practices in the EU can be expected to converge and gradually become more shareholder-oriented in the near future. 


\section{Notes}

1 In chapter 4, I do not study the tendency to meet or beat analyst earnings forecasts, one of the accounting properties I investigate in chapter 3, because I do not have the required data available for the all countries included in the sample.

2 The actual adoption percentage in the EU is lower, because firms from the United Kingdom and Ireland are excluded from the analyses, where no firms adopted non-local GAAP in 1999, and because relatively more non-adopter than adopter observations are lost because of data availability constraints. 


\section{References}

Ahmed, A.S., B.K. Billings, R.M. Morton, and M. Stanford-Harris (2002). The role of accounting conservatism in mitigating bondholder-shareholder conflicts over dividend policy and in reducing debt costs. The Accounting Review 77, 867890.

Alford, A., J. Jones, R. Leftwich, and M. Zmijewski (1993). The relative informativeness of accounting disclosures in different countries. Journal of Accounting Research 31, 183-223.

Ali, A. and L. Hwang (2000). Country-specific factors related to the value relevance of accounting data. Journal of Accounting Research 38, 1-21.

Armstrong, C., M.E. Barth, A. Jagolinzer, and E.J. Riedl (2007). Market reaction to the adoption of IFRS in Europe. Working paper, Stanford University and Harvard Business School.

Ashbaugh, H. (2001). Non-U.S. firms accounting standards choices. Journal of Accounting and Public Policy 20, 129-53.

Ashbaugh, H. and M. Pincus (2001). Domestic accounting standards, International Accounting Standards, and the predictability of earnings. Journal of Accounting Research 39, 17-34.

Auer, K.V. (1996). Capital market reactions to earnings announcements: empirical evidence on the difference in the information content of IAS-based earnings and EC-Directives-based earnings. European Accounting Review 5, 587-623.

Auer, K.V. (1998). Der Einfluß des Wechsels vom Rechnungslegungsstandard auf die Risikoparameter von schweizerischen Aktien. Zeitschrift für Betriebswirtschaftliche Forschung 50, 129-155.

Ball, R. (2001). Infrastructure requirements for an economically efficient system of public financial reporting and disclosure. Brookings Wharton Papers on Financial Services.

Ball, R. and L. Shivakumar (2005). Earnings quality in U.K. private firms:

Comparative loss recognition timeliness. Journal of Accounting and Economics 39, 83-128.

Ball, R., A. Robin, and J.S. Wu (2003). Incentives versus standards: properties of accounting income in four East Asian countries. Journal of Accounting and Economics 36, 235-270.

Ball, R., S.P. Kothari, and A. Robin (2000). The effect of international institutional factors on properties of accounting earnings. Journal of Accounting and Economics 29, 1-51. 
Barth, M.E., W.H. Beaver, and W.R. Landsman (1998). Relative valuation roles of equity book value and net income as a function of financial health. Journal of Accounting and Economics 25, 1-34.

Bartov, E. and G.M. Bodnar (1996). Alternative accounting methods, information asymmetry and liquidity: theory and evidence. The Accounting Review 71, 397-418.

Bartov, E., D. Givoly, and C. Hayn (2002). The rewards to meeting or beating earnings expectations. Journal of Accounting and Economics 33, 173-204.

Basu S. (1997). The conservatism principle and the asymmetric timeliness of earnings. Journal of Accounting and Economics 24, 3-37.

Beasley, M.S. (1996). An empirical analysis of the relation between the board of director composition and financial statement fraud. The Accounting Review 71, 443-465.

Beatty, A. and D. Harris (1999). The effects of taxes, agency costs and information asymmetry on earnings management: A comparison of private firms. Review of Accounting Studies 4, 299-326.

Beatty, A., B. Ke, and K. Petroni (2002). Earnings management to avoid earnings declines across publicly and privately held banks. The Accounting Review 77, 547-570.

Beaver, W.H. and S.G. Ryan (2000). Biases and lags in book value and their effects on the ability of the book-to-market ratio to predict book return on equity. Journal of Accounting Research 38, 127-148.

Becht, M. and A. Röell (1999). Blockholdings in Europe: An international comparison. European Economic Review 43, 1049-1056.

Becht, M. and C. Mayer (2001). Introduction. In: F. Barca and M. Becht, (Eds.), The Control of Corporate Europe. Oxford: Oxford University Press, pp. 1-45.

Beekes, W., P. Pope, and S. Young (2003). The link between earnings timeliness, earnings conservatism and board composition: Evidence from the UK. Corporate Governance: An International Review 12, 47-59.

Biddle, G.C. and S.M. Saudagaran (1991). Foreign stock listings: benefits, costs, and the accounting policy dilemma. Accounting Horizons 5, 69-80.

Botosan, C.A. (1997). Disclosure level and the cost of equity capital. The Accounting Review 77, 323-49.

Botosan, C.A. and Plumlee, M.A. (2002). A re-examination of disclosure level and the expected cost of equity capital. Journal of Accounting Research 40, 21-40.

Burgstahler, D., L. Hail, and C. Leuz (2006). The importance of reporting incentives: Earnings management in European private and public firms. The Accounting Review, Forthcoming. 
Buijink, W.F.J. and R.C.W. Eken (1999). The Netherlands. In: S. McLeay (Ed.), Accounting regulation in Europe. Basingstoke: MacMillan, pp. 237-269.

Cairns, D. (2001). International Accounting Standards survey 2000, David Cairns International Financial Reporting.

Chang, J.J., T. Khanna, and K. Palepu (2000). Analyst activity around the world. Working paper, Harvard Business School.

Cheng, Q. and T. Warfield (2005). Equity incentives and earnings management. The Accounting Review 80, 441-476.

Chow, C.W. and A. Wong-Boren (1987). Voluntary financial disclosure by Mexican corporations. The Accounting Review 62, 533-41.

Commission of the European Communities (1995). Accounting harmonisation: a new strategy vis-à-vis international harmonisation. COM 95 (508), Brussels.

Commission of the European Communities (2001a). Financial reporting: the IAS Regulation - Frequently Asked Questions. On the Internet as per February 2001 (http://europa.eu.int/comm/internal_market/en/firm/account/news/iasfaq.htm).

Commission of the European Communities (2001b). Proposal for a regulation of the European Parliament and of the Council on the application of international accounting standards. COM(2001) 80 final, 2001/0044(COD), Brussels.

Cooke, T.E. (1992). The impact of size, stock market listing and industry type on disclosure in the annual reports of Japanese listed corporations. Accounting and Business Research 22, 229-37.

Coppens, L. and E. Peek (2005). An analysis of earnings management by European private firms. Journal of International Accounting, Auditing and Taxation 14, 1-17.

Core, J.E., R.W. Holthausen, and D.F. Larcker (1999). Corporate governance, chief executive officer compensation, and firm performance. Journal of Financial Economics 51, 371-406.

Council for Annual Reporting (1999). Guidelines for annual reporting in the Netherlands. Deventer: Kluwer.

d'Arcy A. (2000). The degree of determination of national accounting systems: An empirical investigation. Schmalenbach Business Review 52, 54-67.

Daske, H. (2006). Economic benefits of adopting IFRS or US-GAAP - Have the expected cost of equity capital really decreased? Journal of Business Finance \& Accounting 33, 329-373.

De Jong, A. (2002). The disciplining role of leverage in Dutch firms. European Finance Review 6, 31-62.

De Jong, A., R. Kabir, T. Marra, and A. Röell (2001). Ownership and control in The Netherlands. In: F. Barca and M. Becht. (Eds.), The Control of Corporate Europe. Oxford: Oxford University Press, pp. 188-206. 
Dechow, P.M., S.A. Richardson and I. Tuna (2003). Why are earnings kinky? An examination of the earnings management explanation. Review of Accounting Studies 8, 355-384.

DeFond, M.L. and J. Jiambalvo (1994). Debt covenant violation and earnings management. Journal of Accounting and Economics 17, 145-176.

Degeorge, F., J. Patel, and R. Zeckhauser (1999). Earnings management to exceed thresholds. Journal of Business 72, 1-33.

Dietrich, J.R., K.A. Muller, E.J. Riedl (2004). Asymmetric timeliness tests of accounting conservatism. Working paper, Ohio State University.

Dumontier, P. and B. Raffournier (1998). Why firms comply voluntarily with IAS: an empirical analysis with Swiss data. Journal of International Financial Management and Accounting 9, 216-45.

Eames, M., S. Glover, and J. Kennedy (2002). The association between trading recommendations and broker-analysts earnings forecasts. Journal of Accounting Research 40, 85-104.

Easton, P., G. Taylor, P. Shroff, and T. Sougiannis (2002). Using forecasts of earnings to simultaneously estimate growth and return on equity investment. Journal of Accounting Research 40, 657-76.

El-Gazzar, S.M., P.M. Finn, and R. Jacob (1999). An empirical investigation of multinational firms compliance with International Accounting Standards, The International Journal of Accounting 34, 239-48.

European Parliament and Council (2002). Regulation of the European Parliament and of the Council on the application of international accounting standards. PECONS 3626/02 - DRS 28 - CODEC 544 - 2001/0044(COD), Brussels, 27 May.

Faccio, M. and L.H.P. Lang (2002). The ultimate ownership of Western European corporations. Journal of Financial Economics 65, 365-395.

Fama, E.F. (1980). Agency problems and the theory of the firm. Journal of Political Economy 88, 288-307.

Fama, E.F. and M.C. Jensen (1983). Separation of ownership and control. Journal of Law and Economics 26, 301-325.

Fan, J.P.H. and T.J. Wong (2002). Corporate ownership structure and the informativeness of earnings in East Asia. Journal of Accounting and Economics 33, 401-425.

Fédération des Experts Comptables Européens (1993). Seventh Directive options and their implementation. Fédération des Experts Comptables Européens/Routledge, London.

Fédération des Experts Comptables Européens (2001). Enforcement mechanisms in Europe: a preliminary investigation of oversight systems, April. 
Flower, J. (2004). European financial reporting: adapting to a changing world. Palgrave MacMillan.

Foster, G. (1986). Financial statement analysis, $2^{\text {nd }}$ edn. Upper Saddle River, NJ: Prentice-Hall.

Guay, W.R., S.P. Kothari, and S. Shu (2003). Properties of Implied Cost of Capital Using Analysts Forecasts, Working paper, MIT Sloan.

Haller, A. (2002). Financial accounting developments in the European Union: past events and future prospects. European Accounting Review 11, 153-90.

Healy, P.M. and K.G. Palepu (2001). Information asymmetry, corporate disclosure, and the capital market: a review of the empirical disclosure literature. Journal of Accounting and Economics 31, 405-40.

Hermann, D. and T. Inoue (1996). Income smoothing and incentives by operating condition: An empirical test using depreciation changes in Japan. Journal of International Accounting, Auditing and Taxation 5, 161-177.

Holthausen, R.W. (2003). Testing the relative power of accounting standards versus incentives and other institutional features to influence the outcome of financial reporting in an international setting. Journal of Accounting and Economics 36, 271-283.

Hribar, P. and D.W. Collins (2002). Errors in estimating accruals: Implications for empirical research. Journal of Accounting Research 40, 105-134.

Hung, M. (2001). Accounting standards and value relevance of financial statements: An international analysis. Journal of Accounting and Economics 30, 401-420.

International Accounting Standards Committee (2000). Companies referring to their use of IAS. On the Internet as per May 2000 (www.iasc.org.uk).

International Accounting Standards Committee (2001). Companies referring to their use of IAS. On the Internet as per February 2001 (www.iasc.org.uk).

International Organisation of Securities Commissions (2000). IASC standards assessment report. Report of the Technical Committee of the International Organisation of Securities Commissions, May.

Jaggi, B. and P.Y. Low (2000). Impact of culture, market forces, and legal system on financial disclosures. The International Journal of Accounting 35, 495-519.

Jensen, M.C. (1986). Agency cost of free cash flow, corporate finance, and takeovers, American Economic Review 76, 323-329.

Jensen, M.C. (1993). The modern industrial revolution, exit, and the failure of internal control systems. The Journal of Finance 48, 831-880.

Joos, P. and M. Lang (1994). The effects of accounting diversity: Evidence from the European Union. Journal of Accounting Research 32 Supplement, 141-168. 
Joos, P. and V. Weets (2000). Impact of the introduction of the euro on financial reporting in the EMU. Vierentwintigste Vlaams Wetenschappelijk Economisch Congres, Gent, 17-18 March.

Kabir, R., D. Cantrijn, and A. Jeunink (1997). Takeover defenses, ownership structure and stock returns in The Netherlands: An empirical analysis. Strategic Management Journal 18, 97-109.

Kaplan, S.N. and D. Reishus (1990). Outside directorships and corporate performance. Journal of Financial Economics 27, 389-410.

Ke, B., K. Petroni, and A. Saffieddine (1999). Ownership concentration and sensitivity of executive pay to accounting performance measures: Evidence from publicly and privately-held insurance companies. Journal of Accounting and Economics 28, 185-209.

Krishnaswami, S. and V. Subramaniam (1999). Information asymmetry, valuation, and the corporate spin-off decision. Journal of Financial Economics, 53: 73-112.

LaFond, R. (2005). The influence of ownership structure on earnings conservatism and the informativeness of stock prices: An international comparison. Working paper, Sloan School of Management, Massachusetts Institute of Technology.

La Porta, R., F. Lopez-de-Silanes, A. Shleifer, and R.W. Vishny (1998). Law and finance. Journal of Political Economy 106, 1113-55.

La Porta, R., F. Lopez-de-Silanes, and R.W. Vishny (1999). Corporate ownership around the world. The Journal of Finance 54, 471-517.

Lang, M. and R. Lundholm (1993). Cross-sectional determinants of analyst ratings of corporate disclosures. Journal of Accounting Research, 31, 246-71.

Lang, M.H. and R.J. Lundholm (1996). Corporate disclosure policy and analyst behaviour. The Accounting Review 71, 467-92.

Lang, M.H., K.V. Lins, and D.P. Miller (2003). ADRs, analysts, and accuracy: does cross listing in the U.S. improve a firms information environment and increase market value? Journal of Accounting Research 41, 317-345.

Lang, M.H., K.V. Lins, and D.P. Miller (2004). Concentrated control, analyst following and valuation: Do analysts matter most when investors are protected least. Journal of Accounting Research 42, 589-623.

Leuz, C. (2003). IAS versus U.S. GAAP: Information asymmetry-based evidence from Germanys New Market. Journal of Accounting Research 41, 445-472.

Leuz, C. and R.E. Verrecchia (2000). The economic consequences of increased disclosure. Journal of Accounting Research 38 Supplement, 91-124.

Leuz, C., D. Nanda, P.D. Wysocki (2003). Earnings management and investor protection: an international comparison. Journal of Financial Economics 69, 505-527. 
Leuz, C. and J.Wüstemann (2004). The role of accounting in the German financial system. In: J.P. Krahnen and R.H. Schmidt (Eds.), The German financial system. London: Oxford University Press. pp. 450-483.

Maddala, G.S. (1991). A perspective on the use of limited-dependent and qualitative variables models in accounting research. The Accounting Review 66, 788-807.

Maddala, G.S. (2001). Introduction to econometrics, $3^{\text {rd }}$ edn. New York: John Wiley \& Sons.

Matsumoto, D.A. (2002. Managements incentives to avoid negative earnings surprises. The Accounting Review 77, 483-514.

Meek, G.K., C.B. Roberts, and S.J. Gray (1995). Factors influencing voluntary annual report disclosures by U.S., U.K. and continental European multinational corporations. Journal of International Business Studies 26, 555-72.

Meuwissen, R., F. Moers, E. Peek, and A. Vanstraelen (2006). An evaluation of abnormal accruals measurement models in an international context. Working paper, Maastricht University and University of Antwerp.

Murphy, A.B. (1999). Firm characteristics of Swiss companies that utilize International Accounting Standards. International Journal of Accounting 35, 121-31.

Newey, W.K. and K.D. West (1987). A simple, positive semi-definite, heteroskedasticity and autocorrelation consistent covariance matrix. Econometrica 55, 703-708.

Nobes, C. and R. Parker (1998). Comparative international accounting, $5^{\text {th }}$ edn. London: Prentice-Hall Europe.

Nobes, C.W. (2000). GAAP 2000: A survey of national accounting rules in 53 countries. PricewaterhouseCoopers.

Palepu, K.G. (1986). Predicting takeover targets: A methodological and empirical analysis. Journal of Accounting and Economics 8, 3-35.

Peek, E. (2004). The use of discretionary provisions in earnings management: Evidence from The Netherlands. Journal of International Accounting Research 3, 27-43.

Peek, E., R. Cuijpers, W.F.J. Buijink (2007). Creditors' and shareholders' reporting demands in public versus private firms: Evidence from Europe. Working paper, Maastricht University and Tilburg University.

Richardson, S., S.H. Teoh, and P.D. Wysocki (2004). The walk-down to beatable analyst forecasts: the role of equity issuance and insider trading incentives. Contemporary Accounting Research 21, 885-924.

Saudagaran, S.M. and G.C. Biddle (1995). Foreign listing location: a study of MNCs and stock exchanges in eight countries. Journal of International Business Studies 26, 319-41. 
SER (Sociaal-Economische Raad, Social and Economic Council) (1969). De herziening van het ondernemingsrecht (The revision of company law). SociaalEconomische Raad 69/14.

Shleifer, A. and R.W. Vishny (1986). Large shareholders and corporate control. Journal of Political Economy 94, 461-488.

Stein, J.C. (1988). Takeover threats and managerial myopia. Journal of Political Economy 96, 61-80.

Tucker, J.W. and P.A. Zarowin (2006). Does income smoothing improve earnings informativeness? The Accounting Review 82, 443-472.

Vafeas, N. (2000). Board structure and the informativeness of earnings. Journal of Accounting and Public Policy 19, 139-160.

Voogd, R.P. (1989). Statutaire beschermingsconstructies bij beursvennootschappen (Statutory anti-takeover defense mechanisms at listed companies). Unpublished dissertation, Katholieke Universiteit Nijmegen.

Warfield, T., J.J. Wild, K. Wild (1995). Managerial ownership, accounting choices, and informativeness of earnings. Journal of Accounting and Economics 20, 6191.

White, H. (1980). A heteroskedasticity-consistent covariance matrix estimator and a direct test for heteroskedasticity. Econometrica, 48, 817-838.

Yeo, G.H.H., P.M.S. Tan, K.W. Ho, and S. Chen (2002). Corporate ownership structure and the informativeness of earnings. Journal of Business Finance \& Accounting 29, 1023-1046.

Yermack, D. (1996). Higher market valuation of companies with a smaller board of directors. Journal of Financial Economics 40, 185-213.

Zambon, S. (1998). Italy, in: Alexander, D. and Archer, S. (eds.) European Accounting Guide, $3^{\text {rd }}$ edn. San Diego/London: Harcourt Brace \& Firm, pp. 523-669.

Zarzeski, M.T. (1996). Spontaneous harmonization effects of culture and market forces on accounting disclosure practices. Accounting Horizons 10, 18-37.

Zmijewski, M. (1984). Methodological issues related to the estimation of financial distress prediction models. Journal of Accounting Research 22(supplement), 59-82. 


\section{Summary in Dutch (Nederlandse samenvatting)}

\section{Determinanten van verslaggevingskeuzes: de rol van institutionele en bedrijfsspecifieke factoren}

Dit proefschrift bestudeert de determinanten van verslaggevingskeuzes van ondernemingen aan de hand van drie empirische studies. Verslaggevingskeuzes worden gemaakt op verschillende niveaus. Ten eerste kunnen bedrijven in bepaalde gevallen kiezen welke set verslaggevingsstandaarden ze gebruiken. Voor het gebruik van International Financial Reporting Standards (IFRS) verplicht werd voor beursgenoteerde ondernemingen in de Europese Unie, bijvoorbeeld, was het in een aantal landen al toegestaan om U.S. generally accepted accounting principles (GAAP) of IFRS, in plaats van lokale verslaggevingsstandaarden, toe te passen voor het opstellen van de geconsolideerde jaarrekening. Ten tweede dienen ondernemingen binnen een set verslaggevingsstandaarden schattingen en keuzes voor bepaalde waarderingsmethoden te maken. Zo maken ondernemingen schattingen ten aanzien van de hoogte van garantievoorzieningen en staat IFRS toe vaste activa te waarderen tegen historische kostprijs of vervangingswaarde.

In hoofdstuk 2 onderzoek ik de determinanten en de gevolgen van vrijwillige adoptie van IFRS of U.S. GAAP door beursgenoteerde ondernemingen in de Europese Unie (EU). Verwacht wordt dat bedrijven kiezen voor deze verslaggevingsstandaarden in plaats van lokale standaarden indien de voordelen van adoptie opwegen tegen de kosten. Het blijkt dat in 1999 slechts 133 ondernemingen vrijwillig IFRS of U.S. GAAP gebruiken. Dit suggereert dat het slechts voor weinig ondernemingen voordelig is om deze standaarden toe te passen. Bedrijven die deze standaarden gebruiken zijn vaker genoteerd aan de EASDAQ aandelenbeurs of aan een aandelenbeurs in de Verenigde Staten. Verder zijn de activiteiten van deze ondernemingen geografisch meer gespreid en komen ze vaker uit landen waar lokale verslaggevingsregels van lagere kwaliteit zijn en waar IFRS expliciet als alternatief voor lokale standaarden is toegestaan.

Bedrijven die IFRS of U.S. GAAP vrijwillig gebruiken blijken, tegen mijn verwachtingen in, geen lagere kapitaalkosten te hebben. Wel worden deze bedrijven door meer financiële analisten gevolgd. De spreiding van winstvoorspellingen van analisten voor deze bedrijven blijkt echter groter te zijn, wat kan duiden op grotere informatieasymmetrie tussen ondernemingen en investeerders. Nadere analyse leert 
echter dat dit effect alleen optreedt voor de 'late' adopters, bedrijven die in 1998 of 1999 IFRS of U.S. GAAP hebben ingevoerd, en niet voor de 'early' adopters.

In hoofdstuk 3 bestudeer ik de invloed van de corporate governance structuur van ondernemingen op hun verslaggevingskeuzes. De setting van de studie, Nederland, is gekozen vanwege de grote mate van flexibiliteit die ondernemingen hebben in hun financiële verslaggeving en de substantiële verschillen in corporate governance tussen ondernemingen. Nederlandse verslaggevingsregels zijn, evenals IFRS, primair gericht op informatievoorziening aan aandeelhouders. Echter, gedurende de onderzochte periode (1991-2000), is het gebruik van de Richtlijnen voor de Jaarverslaggeving (Guidelines for Annual Reporting) vrijwillig en is het toezicht op de verslaggeving van ondernemingen relatief zwak. Nederlandse corporate governance in deze periode wordt gekenmerkt door het veelvuldige gebruik van beschermingsconstructies door ondernemingen, het bestaan van het structuurregime en de grote variantie in de concentratie van aandelenbezit tussen ondernemingen.

Ik verwacht dat ondernemingen met gespreid aandelenbezit, ondernemingen die niet onder het structuurregime vallen en ondernemingen zonder beschermingsconstructies (shareholder-georiënteerde corporate governance), verslaggevingskeuzes maken in het belang van de informatieverstrekking aan aandeelhouders. In ondernemingen met geconcentreerd aandelenbezit, ondernemingen die onder het structuurregime vallen en ondernemingen met beschermingsconstructies (stakeholder-georiënteerde corporate governance), verwacht ik dat verslaggeving een belangrijke rol speelt in het bepalen van de winstbestemming. Specifiek verwacht ik dat managers van bedrijven met stakeholder-georiënteerde governance structuren conservatieve verslaggevingskeuzes maken en winsten proberen te egaliseren om zodoende te hoge uitkeringen aan de verschillende stakeholders van de onderneming te voorkomen en voor voldoende interne financiering te zorgen. Managers van bedrijven met shareholder-georiënteerde governance structuren zullen daarentegen aan de vraag van aandeelhouders voor informatieve verslaggeving willen voldoen, en dus niet noodzakelijk conservatieve en winstegaliserende verslaggevingskeuzes maken.

Stakeholder-georiënteerde governance structuren zorgen er echter ook voor dat managers minder onder druk staan van de kapitaalmarkt, omdat de relatief zwakke macht van aandeelhouders in deze ondernemingen ervoor zorgt dat de kans op een overname uiterst klein is. Voor ondernemingen met shareholder-georiënteerde governance structuren is de druk van de overnamemarkt groter en de nadruk op het behalen van korte-termijn winsten relatief hoog. Specifiek verwacht ik dat managers van bedrijven met shareholder-georiënteerde governance structuren flexibiliteit in verslaggeving meer zullen gebruiken om zo winstvoorspellingen van analisten proberen te overschrijden dan managers van bedrijven met stakeholder-georiënteerde governance structuren. 
De resultaten van de studie zijn in lijn met deze verwachtingen en laten zien ondernemingen met een stakeholder-georiënteerde governance structuur conservatiever rapporteren, winsten meer egaliseren en minder vaak analistenvoorspellingen proberen te behalen dan bedrijven met een shareholdergeoriënteerde governance structuur.

In hoofdstuk 4 onderzoek ik de invloed van institutionele (landspecifieke) factoren op verslaggevingskeuzes van ondernemingen met verschillende aandeelhoudersstructuren in West-Europa. Ik verwacht dat de institutionele oriëntatie van een land een grotere invloed heeft op ondernemingen met geconcentreerd aandelenbezit dan op ondernemingen met verspreid aandelenbezit. Ik classificeer de institutionele oriëntatie van een land ten aanzien van financiële verslaggeving als stakeholder- of shareholder-georiënteerd. De institutionele omgeving in shareholdergeoriënteerde landen is gericht op de rol van verslaggeving in de informatievoorziening aan aandeelhouders, terwijl de nadruk in stakeholdergeoriënteerde landen ligt op de rol van verslaggeving in het bepalen van de winstbestemming. Evenals in hoofdstuk 3, classificeer ik bedrijven met geconcentreerd aandelenbezit als stakeholder-georiënteerd en bedrijven met verspreid aandelenbezit als shareholder-georiënteerd. Wanneer de ondernemingsspecifieke verslaggevingsoriëntatie niet in lijn is met de institutionele verslaggevingsoriëntatie, ontstaat er een kosten-batenafweging voor ondernemingen. De kosten voor bedrijven met geconcentreerd aandelenbezit om stakeholder-georiënteerd te rapporteren in landen met shareholder-georiënteerde instituties zijn relatief hoog, omdat de rechten van individuele aandeelhouders in deze landen goed beschermd zijn en het toezicht op verslaggeving strikt is. Echter, bedrijven met verspreid aandelenbezit kunnen in stakeholder-georiënteerde landen vaak shareholder-georiënteerd rapporteren, omdat de flexibiliteit in verslaggeving en het beperkte toezicht in deze landen het ondernemingen veelal toestaat om bepaalde informatieve verslaggevingskeuzes te maken. Ik verwacht dan ook dat de insitutionele oriëntatie van een land een grotere invloed heeft op ondernemingen met geconcentreerd aandelenbezit dan op ondernemingen met verspreid aandelenbezit.

Ik onderzoek de verslaggevingskeuzes van ondernemingen aan de hand van twee van de kenmerken die ook in hoofdstuk 3 worden onderzocht: de mate waarin een onderneming conservatief rapporteert en de mate van winstegalisatie. De resultaten geven aan dat institutionele factoren de verslaggevingskeuzes van ondernemingen beïnvloeden. Verder vind ik, in lijn met mijn verwachtingen, dat het effect van instituties op de mate waarin ondernemingen conservatief rapporteren, groter is voor ondernemingen met geconcentreerd aandelenbezit dan voor ondernemingen met gespreid aandelenbezit. Ik vind dit effect echter niet voor de mate waarin winsten geëgaliseerd worden. 
Samengevat laten de resultaten van de drie studies laten zien dat behalve regelgeving, ook andere institutionele en bedrijfsspecifieke factoren een invloed hebben op de financiële verslaggeving van ondernemingen. Een belangrijke implicatie is dat de verplichte invoering van IFRS in de EU niet automatisch zal leiden tot informatievere, shareholder-georiënteerde verslaggeving voor alle ondernemingen, omdat, naast regelgeving, andere institutionele en bedrijfsspecifieke factoren niet gelijktijdig veranderen. Naast standaardisatie van verslaggevingsregels, worden echter ook andere institutionele verschillen tussen landen, bijvoorbeeld op het gebied van richtlijnen voor overnames, accountantscontrole en handel met voorkennis, gereduceerd. Het doorvoeren van deze veranderingen vergt echter tijd. Ook resteren er nog belangrijke verschillen tussen landen, ondermeer op het terrein van het toezicht op verslaggeving. Daarnaast zullen bedrijfsspecifieke verschillen die een invloed hebben op verslaggeving, zoals verschillen in financieringsvormen van ondernemingen, slechts geleidelijk verdwijnen. Op de lange termijn zullen deze veranderingen er echter voor zorgen dat financiële verslaggeving in de EU beter vergelijkbaar en meer op de vraag van aandeelhouders gericht wordt. 


\section{Curriculum Vitae}

Rick Cuijpers was born on 28 November 1977 in Sittard, The Netherlands. From 1996 to 2000 he studied Business Economics at the Faculty of Economics and Business Administration of Maastricht University. During his studies he worked as a student assistant at the Department of Accounting and Information Management. After graduation, he started working on his doctoral dissertation at this department. Since March 2007, he is an Assistant Professor at the Department of Accounting and Information Management of Maastricht University.

Rick Cuijpers werd geboren op 28 november 1977 in Sittard. Van 1996 tot 2000 studeerde hij Bedrijfseconomie aan de Faculteit der Economische Wetenschappen en Bedrijfskunde van de Universiteit Maastricht. Tijdens zijn studie was hij werkzaam als studentassistent bij het Departement Accounting and Information Management. Na zijn afstuderen trad hij in dienst bij deze afdeling om aan zijn proefschrift te werken. Sinds maart 2007 is hij Universitair Docent bij het Departement Accounting and Information Management. 